\title{
17. LOWER MIOCENE TO QUATERNARY DIATOM BIOSTRATIGRAPHY OF LEG 57, OFF NORTHEASTERN JAPAN, DEEP SEA DRILLING PROJECT
}

\author{
John A. Barron, U. S. Geological Survey, Menlo Park, California
}

\begin{abstract}
Sediments recovered during Leg 57 provide a nearly complete lower Miocene to Holocene composite reference section for diatoms in the northwestern Pacific. High- and middle-latitude diatoms dominate the assemblages; however, because of the influence of the warm-water Kuroshio Current, low-latitude diatoms are consistently present in low abundance. Low-latitude diatom datums tied to paleomagnetic stratigraphy in the equatorial Pacific show little or no displacement in time at the $40^{\circ} \mathrm{N}$ latitude of the Leg 57 sites. Both highand low-latitude diatom zones are recognizable in the upper Miocene to Quaternary of Sites 438 and 440 and thus allow the first direct detailed correlation of these zonations for the upper Miocene. Eleven new subzones, which offer refinement of the existing high-latitude diatom zonation of the North Pacific, are proposed. In addition, the base of the Denticula lauta Zone is defined, and a new zone, the Actinocyclus ingens Zone, is proposed for the upper lower Miocene.

A late Miocene hiatus spanning the interval from about 5.6 to 6.7 m.y.B.P. is identified at Sites 438 and 440 . Correlative hiatuses occur throughout the middle- and high-latitude North Pacific both on the continental slopes and in the ocean basins. Onshore in California, this interval corresponds with an increase in the rate of sediment accumulation associated with the transition from laminated diatomites to overlying, more massive diatomaceous mudstones. These latest Miocene sedimentologic events apparently are related to a global cooling event.
\end{abstract}

\section{INTRODUCTION}

Neogene diatom biostratigraphy in the North Pacific has progressed rapidly in recent years (Burckle and Opdyke, 1977; Koizumi, 1977). In low latitudes the diatom zonation of Burckle $(1972,1977)$ has found wide acceptance, whereas Koizumi's (1973, 1975b) zonation can readily be applied in high latitudes and in Japan. Several diatom datum levels (first and last occurrences) have been correlated directly with paleomagnetic stratigraphy both in low latitudes (Burckle, 1972; 1978) and in high latitudes (Donahue, 1970; Koizumi, 1975d). Burckle and Opdyke (1977) and Koizumi (1977) have provided cross-correlations of the high- and low-latitude diatom zonations for the Pliocene and Quaternary; however, the lack of suitable and complete stratigraphic sections has prevented detailed correlations of the zonations for the Miocene.

During the Japan Trench Transect of the Deep Sea Drilling Project (Legs 56 and 57, September to December, 1977), a series of excellent Miocene to Quaternary siliceous reference sections were cored along an east to west transect at about $40^{\circ} \mathrm{N}$ latitude across the Japan Trench (Figure 1). Leg 57 recovered a nearly complete Neogene siliceous record as a composite at two sites (Sites 438 and 440 ) which contains fairly common, moderately well-preserved to well-preserved diatoms throughout the section.
The Leg 57 sites lie near the present-day confluence of the cool-water Oyashio Current and the warm-water Kuroshio Current, and the mixture of tropical and highlatitude diatom assemblages that results allows detailed correlation of low- and high-latitude zonations for the middle Miocene through the Holocene. In addition, the Leg 57 sites are near enough to shore (about 130 to 200 $\mathrm{km}$ ) that nearshore planktonic diatoms, which are useful in correlations in Japan and in California, are consistently present.

\section{ZONATION}

The diatom zonation of this chapter is modified slightly from the high-latitude North Pacific diatom zonation of Koizumi (1973, 1975b) (Figure 2). Eleven new subzones and one additional zone, the Actinocyclus ingens Zone, are proposed, and the base of the Denticula lauta Zone is defined. This zonation is summarized below, and additional comments appear in the biostratigraphy section.

Denticula seminae Zone (Koizumi, 1973)

Definition: The interval from the last occurrence of Rhizosolenia curvirostris to the present.

Subzones: None.

Remarks: The last occurrence of Thalassiosira nidulus var. nidulus coincides with the base of the zone (Koizumi, 1977). 

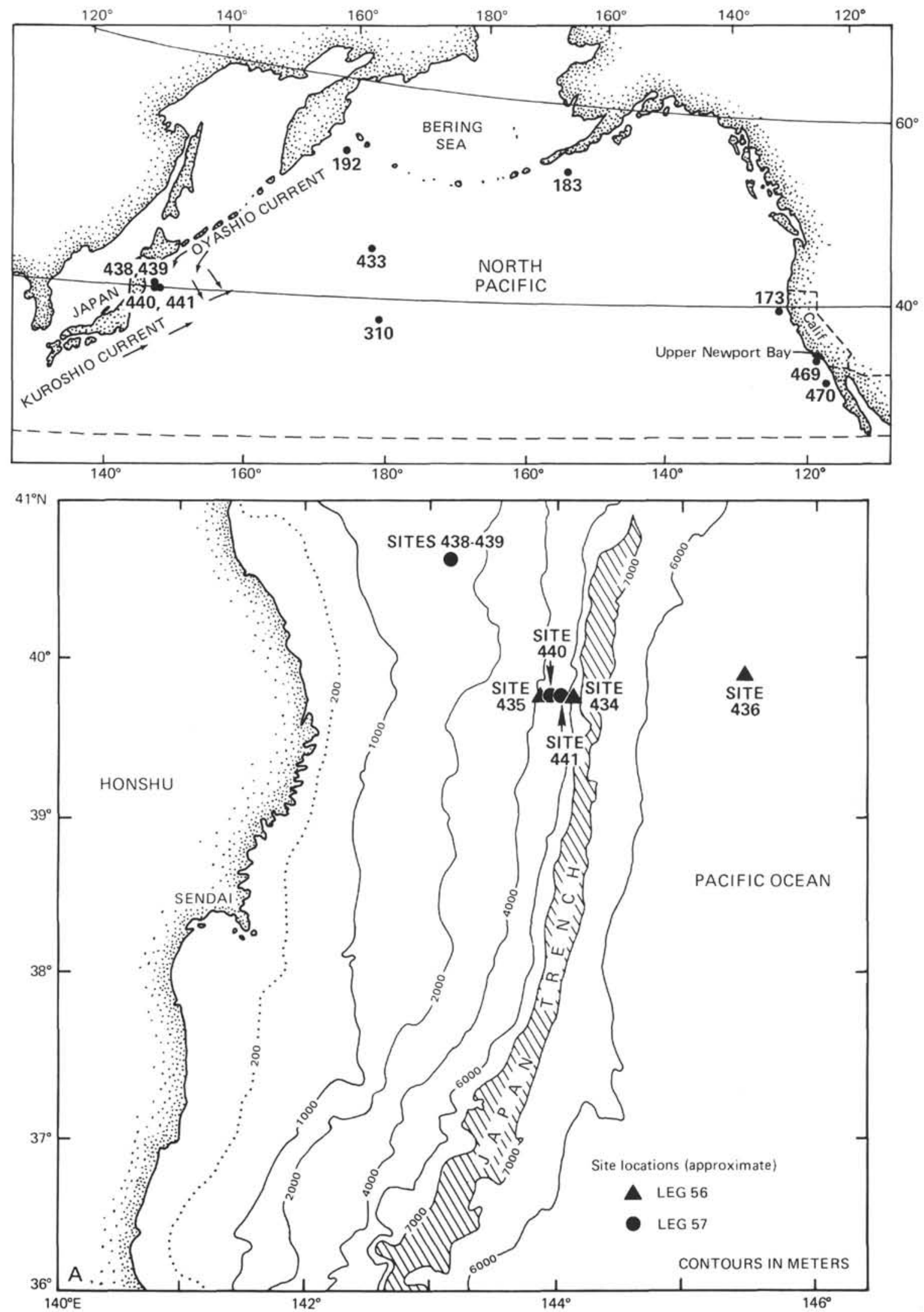

Figure 1. Location of Leg 57 Sites 438 through 441 off northeast Japan and location of other sections in the North Pacific discussed in text. (Numbers refer to DSDP sites.) 


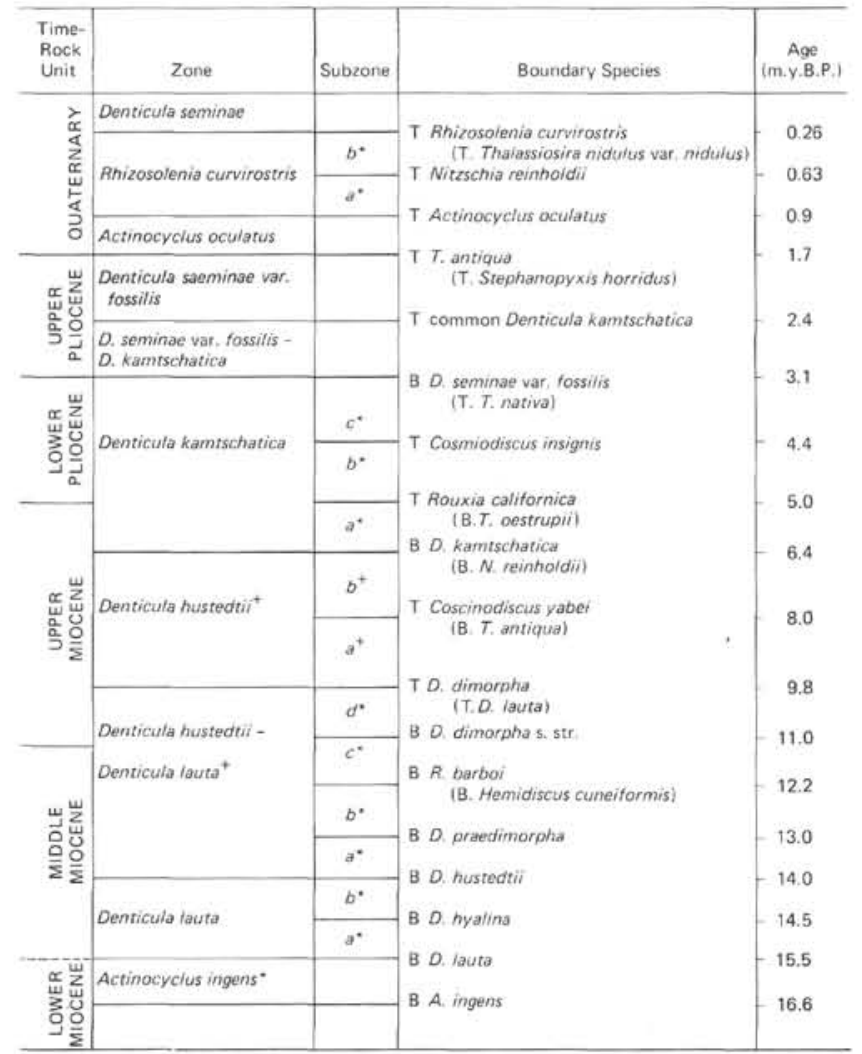

Figure 2. Modification of the diatom zonation of Koizumi $(1973,1975 b)$ used for Leg 57 material. (B = first occurrence, $\mathrm{T}=$ last occurrence. Boundary species that are secondary approximations of the zonal and subzonal boundaries appear in parentheses. Asterisk indicates new zones and subzones. Cross indicates modified zones and subzones.)

Geographic Distribution: Recognizable in the middle- and high-latitude North Pacific.

Paleomagnetic Stratigraphy: The base of the Denticula seminae Zone is in the middle of the Brunhes Epoch (Donahue, 1970; Koizumi, 1975d; Burckle and Opdyke, 1977).

Absolute Age: 0 to 0.26 m.y.B.P. (Donahue, 1970). Rhizosolenia curvirostris Zone (Koizumi, 1973)

Definition: The interval from the last occurrence of Actinocyclus oculatus to the last occurrence of Rhizosolenia curvirostris.

Subzones: Two new subzones are proposed. The last occurrence of Nitzschia reinholdii defines the top of Subzone $a$ and the base of Subzone $b$.

Remarks: The last occurrence of Thalassiosira nidulus var. nidulus coincides with the base of the zone.

Discussion: Schrader (1973) and Burckle and Opdyke (1977) point out the value of the last occurrence datum of Nitzschia reinholdii for correlations in the middle-latitude North Pacific.

Geographic Distribution: The zone is recognizable in the middle- and high-latitude North Pacific. Use of the subzones is confined to the middle latitudes.
Paleomagnetic stratigraphy: The top of the Rhizosolenia curvirostris Zone correlates with the middle of the Brunhes Epoch (Donahue, 1970; Koizumi, 1975d; Burckle and Opdyke, 1977). The base of the zone is in the Jaramillo Event of the Matuyama Epoch (Donahue, 1970; Burckle and Opdyke, 1977).

The Subzone $a$ /Subzone $b$ boundary correlates with the lowermost Brunhes in the northwestern Pacific (Koizumi, 1975d; Burckle and Opdyke, 1977).

Absolute Age: Zone-0.26 to 0.9 m.y.B.P. (Donahue, 1970).

Subzone $b-0.26$ to 0.63 m.y.B.P. Subzone $a-0.63$ to 0.9 m.y.B.P. (from Burckle, 1977).

Actinocyclus oculatus Zone (Koizumi, 1973)

Definition: The interval from the last occurrence of Thalassiosira antiqua to the last occurrence of Actinocyclus oculatus.

Subzones: None.

Remarks: The last occurrences of Coscinodiscus pustulatus and Stephanopyxis horridus coincide with the base of the zone (Koizumi, 1973).

Geographic Distribution: Recognizable in the middle- and high-latitude North Pacific.

Paleomagnetic stratigraphy: The top of the $A c$ tinocyclus oculatus Zone correlates with the Jaramillo Event (Donahue, 1970; Burckle and Opdyke, 1977). The base of the zone is in the Olduvai Event, above the first occurrence of Pseudoeunotia doliolus (Burckle and Opdyke, 1977).

Absolute Age: 0.9 to 1.7 m.y.B.P. (estimate, this chapter).

Denticula seminae var. fossilis Zone (Koizumi, 1975a)

Definition: The interval from the last occurrence of Denticula kamtschatica to the last occurrence of Thalassiosira antiqua.

Subzones: None.

Remarks: The last occurrences of Coscinodiscus pustulatus and Stephanopyxis horridus coincide with the top of the zone. The base of the zone is recognized by the last common occurrence of Denticula kamtschatica in this chapter.

Geographic Distribution: Recognizable in the middle- and high-latitude North Pacific.

Paleomagnetic Stratigraphy: The top of the Denticula seminae var. fossilis Zone is in the Olduvai Event above the first occurrence of Pseudoeunotia doliolus (Burckle and Opdyke, 1977). The base of the zone correlates with the top of the Gauss Epoch (Koizumi, 1975d; Burckle and Opdyke, 1977).

Absolute Age: 1.7 to 2.4 m.y.B.P. (estimate, this chapter).

Denticula seminae var. fossilis-Denticula kamtschatica Zone (Koizumi, 1973)

Definition: The interval from the first occurrence of Denticula seminae var. fossilis to the last occurrence of Denticula kamtschatica.

Subzones: None.

Remarks: In this chapter the top of the zone is recognized by the last common occurrence of $D$. kamt- 
schatica. The last occurrence of Thalassiosira nativa sensu Koizumi (1975b) approximates the base of the zone in Leg 57 sediments.

Geographic Distribution: Recognizable in the middle- and high-latitude North Pacific.

Paleomagnetic Stratigraphy: The top of the $D$. seminae var. fossilis-D. kamtschatica Zone correlates with the top of the Gauss Epoch (Koizumi, 1975d; Burckle and Opdyke, 1977). The base of the zone is tentatively placed in the Gilbert Epoch between the " $b$ " and "c" events by Burckle and Opdyke (1977). In Leg 57 sediments off northeastern Japan, however, the base of the zone appears to be somewhat younger - perhaps correlative with the middle part of the Gauss.

Absolute Age: 2.4 to 4.2 m.y.B.P. (Burckle and Opdyke, 1977).

2.4 to about 3.1 m.y.B.P. (estimate, this chapter).

Denticula kamtschatica Zone (Koizumi, 1973)

Definition: The interval from the first occurrence of Denticula kamtschatica to the first occurrence of Denticula seminae var. fossilis.

Subzones: Three new subzones are proposed. The last occurrence of Cosmiodiscus insignis defines the base of Subzone $c$ and the top of Subzone $b$. The base of Subzone $b$ and the top of Subzone $a$ are defined by the last occurrence of Rouxia californica.

Remarks: The last occurrence of Thalassiosira nativa sensu Koizumi (1975b) approximates the top of the zone in Leg 57 sediments. The first occurrences of Thalassiosira oestrupii and Cussia tatsunokuchiensis and the last occurrence of Goniothecium tenue coincide closely with the Subzone $a$ /Subzone $b$ boundary.

In the middle latitudes of the North Pacific, the first occurrences of Denticula kamtschatica and Nitzschia reinholdii appear to be correlative (Koizumi, 1977; Burckle, 1978; Burckle, written communication, 1978).

Discussion: It is important to distinguish Denticula kamtschatica s. str. from specimens that resemble it but are finer in structure. These finer specimens are referred to Nitzschia rolandii by Harper (1977a) and by Koizumi (in press) (= Denticula sp. cf. D. kamtschatica of this chapter), and they range below the Denticula kamtschatica Zone.

Geographic Distribution: The D. kamtschatica Zone is recognizable in the middle- and high-latitude North Pacific. The first occurrence of Denticula kamtschatica is later in southern California than in the western North Pacific (Harper, 1977a). The first occurrence of N. reinholdii in southern California approximates the base of the D. kamtschatica Zone in the western North Pacific.

All three subzones are recognizable in the western North Pacific. The Subzone $c$ /Subzone $b$ boundary can be determined in the Bering Sea but not in the California area. In California the first occurrence of Thalassiosira oestrupii correlates with the Subzone $b$ /Subzone $a$ boundary (this chapter), but the last occurrence of Rouxia californica is older than it is in the western North Pacific (Harper, 1977a).

Paleomagnetic Stratigraphy: Burckle and Opdyke (1977) tentatively place the top of the $D$. kamtschatica
Zone between the "b" and "c" events of the Gilbert Epoch, but this boundary appears to be somewhat younger in the Leg 57 area off northeastern Japan. The base of the zone correlates with the lower part of Epoch 6 (Burckle, written communication, 1978).

Absolute Age: Zone-4.2 to 6.4 m.y.B.P. (Burckle and Opdyke, 1977; Burckle, written communication, 1978).

3.1 to 6.4 (estimate, this chapter).

Subzone $c-3.1$ to 4.4 m.y.B.P.

Subzone $b-4.4$ to 5.0 m.y.B.P.

Subzone $a-5.0$ to 6.4 m.y.B.P. (estimate, this chapter).

Denticula hustedtii Zone (Koizumi, 1973) (modified, this chapter)

Definition: The interval from the last occurrence of Denticula dimorpha to the first occurrence of Denticula kamtschatica.

Subzones: Labeling of the two subzones of Koizumi (1977) is reversed in this chapter to conform with the convention of numbering zones from oldest to youngest, utilized by Cenozoic calcareous nannofossil and planktonic foraminifer workers.

The last occurrence of Coscinodiscus yabei defines the top of Subzone $a$ and the base of Subzone $b$.

Remarks: The first occurrence of Nitzschia reinholdii approximates the top of the zone in the middle-latitude North Pacific. The Subzone $b /$ Subzone $a$ boundary coincides closely with the first occurrence of Thalassiosira antiqua. The last occurrence of Denticula lauta is near the base of the zone.

Discussion: The last occurrence of Denticula lauta, the traditional base of the Denticula hustedtii Zone, may be difficult to determine because of reworking upsection and because of confusion with $D$. hyalina in poorly preserved sediments. Schrader (1973), Barron (1976), and Koizumi (1977) indicate a close stratigraphic correspondence between the last occurrences of Denticula lauta and $D$. dimorpha in the North Pacific. Denticula dimorpha is a distinctive species with a robust morphology that has been shown to be resistant to dissolution. Consequently I propose to utilize the last occurrence of Denticula dimorpha to define the base of the D. hustedtii Zone.

Geographic Distribution: The D. hustedtii Zone and its subzones can be recognized throughout the middleand high-latitude North Pacific. The first occurrence of Thalassiosira antiqua is useful for distinguishing the Subzone $b /$ Subzone $a$ boundary in California and in the Bering Sea (Barron, unpublished data).

Paleomagnetic Stratigraphy: The top of the D. hustedtii Zone is in the lower part of Epoch 6 (Burckle, written communication, 1978). The last occurrence of Coscinodiscus yabei, the Subzone $b /$ Subzone $a$ boundary, correlates with the middle of Epoch 8 in the equatorial Pacific (Burckle, 1972). This datum does not appear to be displaced in time in the area off northeastern Japan. The base of the $D$. hustedtii Zone is not tied to paleomagnetic stratigraphy, but Koizumi (1977) estimates the absolute age of the base at about 9.5 m.y.B.P. on the basis of radiometric dates in Japan. 
Absolute Age: Zone-6.4 to 9.8 m.y.B.P. Subzone $b-6.4$ to 8.0 m.y.B.P. Subzone $a-8.0$ to 9.8 m.y.B.P. (estimate, this chapter).

Denticula hustedtii-Denticula lauta Zone (Koizumi, 1975b) (modified, this chapter)

Definition: The interval from the first occurrence of Denticula hustedtii to the last occurrence of Denticula dimorpha.

Subzones: Four new subzones are proposed. The first occurrence of Denticula dimorpha s. str. defines the base of Subzone $d$ and the top of Subzone $c$. The Subzone $c$ /Subzone $b$ boundary is defined by the first occurrence of Rhizosolenia barboi. The base of Subzone $b$ and the top of Subzone $a$ is defined by the first occurrence of Denticula praedimorpha.

Remarks: The last occurrence of Denticula lauta approximates the top of the zone. The first occurrence of Hemidiscus cuneiformis is stratigraphically very near the Subzone $c$ /Subzone $b$ boundary in the middle-latitude North Pacific.

Discussion: Akiba (1979) separates Denticula praedimorpha from $D$. dimorpha and includes specimens in which cross bars are not united to the septum.

The first common occurrence of Denticula hustedtii, near the base of the D. hustedtii-D. lauta Zone, probably correlates with the first occurrence of $D$. hustedtii in low latitudes.

Geographic Distribution: The zone and its subzones are recognizable throughout the middle- and high-latitude North Pacific, including the Bering Sea and off southern California and Baja California (Barron, unpublished data).

Paleomagnetic Stratigraphy: The top and the base of the $D$. hustedtii-D. lauta Zone are not tied to paleomagnetic stratigraphy. Koizumi (1977) estimates the absolute ages of the top of the zone at about 9.5 m.y.B.P. and the base at about 14 m.y.B.P. on the basis of radiometric dates in Japan.

Absolute Age: Zone-9.8 to 14.0 m.y.B.P.

Subzone $d-9.8$ to 11.0 m.y.B.P.

Subzone $c-11.0$ to 12.2 m.y.B.P.

Subzone $b-12.2$ to 13.0 m.y.B.P.

Subzone $a-13.0$ to 14.0 m.y.B.P. (estimate, this chapter).

Denticula lauta Zone (top-Koizumi, 1973) (base-this chapter)

Definition: The interval from the first occurrence of Denticula lauta s. str. to the first occurrence of Denticula hustedtii.

Subzones: Two new subzones are proposed. The first occurrence of Denticula hyalina defines the base of Subzone $b$ and the top of Subzone $a$.

Remarks: In southern California, the last occurrence of Annellus californicus approximates the first occurrence of Denticula hyalina, the Subzone $b$ /Subzone $a$ boundary.

Geographic Distribution: The D. lauta Zone and its subzones are recognizable throughout the middle- and high-latitude North Pacific, including the Bering Sea and off southern California (Barron, unpublished data).
Paleomagnetic Stratigraphy: Neither the top nor the base of the $D$. lauta Zone are tied to paleomagnetic stratigraphy. Koizumi (1977) estimates the absolute age of the top of the zone at 14 m.y.B.P. on the basis of radiometric dates in Japan. Burckle (1978) places the last occurrence of Annellus californicus in the lower part of Epoch 15 in the equatorial Pacific. If this datum is synchronous in southern California, the Subzone $b$ /Subzone $a$ boundary should also be in the lower part of Epoch 15.

Absolute Age: Zone-14.0 to about 15.5 m.y.B.P. Subzone $b-14.0$ to about 14.5 m.y.B.P.

Subzone $a$-about 14.5 to about 15.5 m.y.B.P. (estimate, this chapter).

Actinocyclus ingens Zone (new zone, this chapter)

Definition: The interval from the first occurrence of Actinocyclus ingens to the first occurrence of Denticula lauta s. str.

Subzones: None.

Geographic Distribution: Recognizable in the middle- and high-latitude North Pacific, including the Bering Sea and off southern California (Barron, unpublished data).

Paleomagnetic Stratigraphy: None.

Absolute Age: About 15.5 to about 16.6 m.y.B.P. (estimate, this chapter).

\section{EPOCH BOUNDARIES}

Ryan and others (1974) correlate the lower Miocene/ middle Miocene boundary with the upper part of the calcareous nannofossil NN 4 (Helicosphaera ampliaperta) Zone of Martini (1971) and with the middle of the upper reversed event of Paleomagnetic Epoch 16. In the southern California Continental Borderland the first occurrence of Denticula lauta s. str. is high in the $H$. ampliaperta Zone of Bukry (1973a; Barron, unpublished data) and near the first occurrence of the diatom Annellus californicus. Burckle (1978) correlates the first A. californicus with the upper part of Paleomagnetic Epoch 16. These criteria both suggest that the first occurrence of D. lauta s. str. and, hence, the base of the Denticula lauta Zone lie near the lower Miocene/middle Miocene boundary of Ryan and others (1974).

Ryan and others (1974) place the middle Miocene/ upper Miocene boundary within the calcareous nannofossil NN 9 (Discoaster hamatus) Zone of Martini (1971) and correlate it with the lower normal event of Paleomagnetic Epoch 11. The middle Miocene/upper Miocene boundary appears to be within Subzone $c$ of the Denticula hustedtii-Denticula lauta Zone of this chapter.

The Miocene/Pliocene boundary is placed in the lowermost reversed event of the Gilbert Paleomagnetic Epoch by Cita (1975) and Van Couvering and others (1976). Correlations of this report suggest that the Miocene/ Pliocene boundary thus lies just below the Subzone $a$ /Subzone $b$ boundary within the Denticula kamtschatica Zone.

Haq and others (1977) correlate the Pliocene/Quaternary boundary with about the top of the Olduvai 
Paleomagnetic Event and assign it an absolute age of about 1.6 m.y.B.P. This assignment places the Pliocene/ Quaternary boundary slightly above the base of the Actinocyclus oculatus Zone.

The paleomagnetic time scale of LaBrecque and others (1977) is followed except for the Gilbert Paleomagnetic Epoch and Epochs 5 and 6, where the scale of MacDougall and others (1977) offers more precision. Consequently the lower Miocene/middle Miocene boundary is about $15.5 \mathrm{~m}$.y.B.P., the middle Miocene/ upper Miocene boundary is about $11.3 \mathrm{~m} . \mathrm{y} . \mathrm{B} . \mathrm{P}$., and the Miocene/Pliocene boundary is between 5.1 and 5.2 m.y.B.P. It should be remembered that use of these updated paleomagnetic time scales may result in absolute ages for the epoch boundaries different from those of Ryan and others (1974).

\section{METHODS}

Strewn slides of unprocessed sediment were prepared onboard the D/V Glomar Challenger. These were reexamined together with strewn slides of sediment treated with hydrogen peroxide and hydrochloric acid, using the procedures outlined by Barron (1976). One coverslip $(22 \times 40 \mathrm{~mm})$ was traversed in entirety at $500 \times$ by light microscope. Identifications were checked at $1250 \times$. Taxa were recorded as abundant if two or more specimens were present within one field of view at $500 \times$ (446- $\mu \mathrm{m}$ diameter); common, if one specimen occurred in two fields of view; few, if one specimen was encountered during one vertical traverse (22 mm long); and rare, if specimens were sparser.

In general, only stratigraphically diagnostic diatoms were tabulated. Schrader (1973), Koizumi $(1973,1975$ b, 1977), Burckle (1972, 1977, 1978), Burckle and Opdyke (1977), and Barron (1976) served as the more important references used to select stratigraphic taxa. In addition, a selected number of silicoflagellate taxa found by Barron (1976) and Burckle (1977) to provide useful checks of the diatom biostratigraphy were also tabulated. Brief notes and taxonomic references for these stratigraphically useful diatoms and silicoflagellates appear in the Appendix.

\section{BIOSTRATIGRAPHY}

\section{Site 438}

Site $438\left(40^{\circ} 37.75^{\prime} \mathrm{N}, 143^{\circ} 19.90^{\prime} \mathrm{E}\right.$; water depth $1552 \mathrm{~m}$ ) was drilled shoreward of the Japan Trench to test the seaward extent of continental crust and to provide a Miocene to Quaternary reference section for the upper continental slope.

Diatoms are present throughout the 1040.7-meterthick lower Miocene to Holocene section (Holes 438, $438 \mathrm{~A}$, and $438 \mathrm{~B}$ ) cored at Site 438. Preservation is generally good to moderate in the upper Miocene to Holocene, mostly moderate in the middle Miocene, and moderate to poor in the lowermost middle Miocene and lower Miocene. Figure 3 gives the zonal assignments of the sediment cored at Site 438 and other Leg 57 sites.

\section{Hole 438}

The occurrence of selected stratigraphically important diatoms in the 106.9-meter section cored in Hole 438 is shown in Table 1. Diatom assemblages of the Denticula seminae var. fossilis Zone (upper Pliocene) through the $D$. seminae Zone (upper Quaternary) are present. Reworked middle and upper Miocene diatoms such as D. hustedtii, D. lauta, and Actinocyclus ingens occur sparsely throughout the hole.

The last occurrence of Rhizosolenia curvirostris in Sample $438-2-4,79-81 \mathrm{~cm}(10.3 \mathrm{~m})$, marks the top of the Rhizosolenia curvirostris Zone. The last occurrences of Thalassiosira nidulus var. nidulus and $R$. barboi also are at this zonal boundary at Sites 438 and 440 . Koizumi (1977) reports the last occurrence of $R$. barboi within the lower Quaternary Actinocyclus oculatus Zone; but Donahue (1970) notes that the last occurrence of $R$. curvirostris var. inermis, a synonym of $R$. barboi, coincides with the last occurrence of $R$. curvirostris. Within the $R$. curvirostris Zone, $R$. hebetata $\mathrm{f}$. hiemalis has its first occurrence in Sample 438-3-2, 34-36 cm (16.3 m), and corresponds with the last occurrence of the flat form of Thalassiosira gravida. Rhizosolenia hebetata $\mathrm{f}$. hiemalis first occurs in the upper Pliocene in the high-latitude North Pacific (Koizumi, 1973). The later appearance of this cold-water form off northeastern Japan probably reflects warmer late Pliocene and early Quaternary paleotemperatures. The lower Quaternary Actinocyclus oculatus Zone is present only in Sample 438-3-6, $141-143 \mathrm{~cm}(20.4 \mathrm{~m})$.

The last occurrence of Thalassiosira antiqua in Sample $438-5-1,140-142 \mathrm{~cm}(35 \mathrm{~m})$, marks the top of the upper Pliocene Denticula seminae var. fossilis Zone. The last occurrences of $T$. zabelinae, Coscinodiscus pustulatus, and Stephanopyxis horridus all coincide with the top of this zone as reported by Koizumi (1973).

The top of the $D$. seminae var. fossilis-D. kamtschatica Zone is placed at the last common occurrence of $D$. kamtschatica in Sample 438-8-1, 120-122 cm (63.2 m). Denticula kamtschatica occurs as rare, presumably reworked specimens throughout the upper Pliocene in Hole 438, but correlations with Hole 440B suggest that the last common $D$. kamtschatica closely approximates 2.4 m.y.B.P., or the top of the Gauss Paleomagnetic Epoch where Burckle and Opdyke (1977) and Koizumi (1975d) place the top of the $D$. seminae var. fossilis- $D$. kamtschatica Zone. The first common occurrence of $D$. seminae var. fossilis in Sample 438-9-4, 100-102 cm (77 $\mathrm{m}$ ), is near the top of the zone, and the last occurrence of Nitzschia jouseae lies somewhat lower in Sample 438-12-1, 80-83 cm (100.8 m). Burckle and Opdyke (1977) correlate the last $N$. jouseae with the upper part of the Gauss, and Shackleton and Opdyke (1977) note an increase in the scale of glaciations near the top of the Gauss in the oxygen isotope record in the equatorial Pacific. The first common occurrence of $D$. seminae var. fossilis above the last occurrence of Nitzschia jouseae and immediately below the last common occurrence of D. kamtschatica in Hole 438 may represent this apparent early late Pliocene cooling. The last occur- 


\begin{tabular}{|c|c|c|c|c|c|c|c|}
\hline Zone & Subzone & 438 & 438A & 4388 & 439 & $\begin{array}{c}440,440 \mathrm{~A} \\
440 \mathrm{~B}\end{array}$ & $\begin{array}{c}441,441 \mathrm{~A}, \\
441 \mathrm{~B}\end{array}$ \\
\hline Denticuta seminae & - & $1.4 / 2.3$ & 1.1/1, CC & & & $1.2 / 5, \mathrm{CC}$ & $1.2 / 1, \mathrm{CC}$ \\
\hline Rhizosolenia curvirostris & $\frac{b}{a}$ & $2 \cdot 4 / 3.4$ & $\frac{2.1}{2.4}$ & & & $\begin{array}{l}6, \mathrm{CC} / \mathrm{B} 1, \mathrm{CC} \\
\mathrm{B} 2, \mathrm{CC} / \mathrm{B} 6, \mathrm{CC}\end{array}$ & \\
\hline Actinocyclus oculatus & - & $36 / 3 . \mathrm{CC}$ & 2. $\mathrm{CC} / 3 . \mathrm{CC}$ & & & $87, \mathrm{CC} / \mathrm{B} 17, \mathrm{CC}$ & \\
\hline D. seminae vat. fossitis & $=$ & $5 \cdot 1 / 7 . \mathrm{CC}$ & $42 / 5, \mathrm{CC}$ & & & $\mathrm{B} 18, \mathrm{CC} / \mathrm{B} 25, \mathrm{CC}$ & $21 / \mathrm{A}, \mathrm{CC}$ \\
\hline $\begin{array}{l}\text { D. serminae var, fossilis } \\
\text { D. kamtschatica }\end{array}$ & - & 8.1/12,cC & $6 \cdot 1 / 121$ & & & $\mathrm{~B} 26, \mathrm{CC} / \mathrm{B} 33, \mathrm{CC}$ & $7 \cdot 1 / 9, \mathrm{cC}$ \\
\hline D. kamtschatica & $\frac{c}{b}$ & & $\frac{12 . \mathrm{CC} / 28 \cdot 1}{28.4 / 35 \cdot 5}$ & & & $\begin{array}{l}\mathrm{B} 34, \mathrm{CC} / \mathrm{B} 45, \mathrm{CC} \\
\mathrm{B} 46, \mathrm{CC} / \mathrm{B} 55, \mathrm{CC} \\
\mathrm{B} 56, \mathrm{CC} / \mathrm{B} 60, \mathrm{CC}\end{array}$ & $\begin{array}{l}\text { B1.2/A8,CC } \\
A 9, C C / A 10, C C ? \\
A 11 \cdot 1 / B 2 \cdot 2 \\
\end{array}$ \\
\hline D. hustedtii & $\frac{b}{a}$ & & \begin{tabular}{|l}
$42 \cdot 5 / 46.5$ \\
$46, \mathrm{CC} / 54, \mathrm{CC}$
\end{tabular} & 1.cc & $1, \mathrm{CC} / 2, \mathrm{CC}$ & $\mathrm{B} 61, \mathrm{CC} / \mathrm{B} 71, \mathrm{CC}$ & \\
\hline & $\frac{d}{c}$ & & \begin{tabular}{|l|}
$55-1 / 59, \mathrm{CC}$ \\
$60.1 / 641$ \\
\end{tabular} & $2, \mathrm{CC}$ & $3, \mathrm{CC}$ & & \\
\hline D. lauta & $\frac{b}{a}$ & & $\frac{64-3 / 65 . C C}{66-2 / 68-1}$ & & & & \\
\hline D. lauta & b & & $68-5 / 73 \cdot 5$ & & & & \\
\hline & $a$ & & $73, \mathrm{CC} / 83 . \mathrm{CC}$ & $3 \cdot 3 / 41$ & $4, \mathrm{CC} / 5, \mathrm{CC}$ & & \\
\hline Actinocyclus ingens & $=$ & & $84, \mathrm{CC} / 86, \mathrm{CC}$ & $6 \cdot 1 / 23, \mathrm{CC}$ & $7, \mathrm{CC} / 11, \mathrm{CC}$ & & \\
\hline lower Miocene funzonedi) & $=$ & & & & $12, \mathrm{CC} / 20-1$ & & \\
\hline
\end{tabular}

Figure 3. Diatom zonation of selected samples from DSDP Leg 57. (Numbers assigned to zonal intervals are core and section numbers.

Where several samples are assigned to a zone, the highest and lowest stratigraphic determinations are listed with a slash between.)

TABLE 1

Stratigraphic Occurrence of Selected Diatoms and the Silicoflagellate Distephanus boliviensis jimlingii in Hole 438

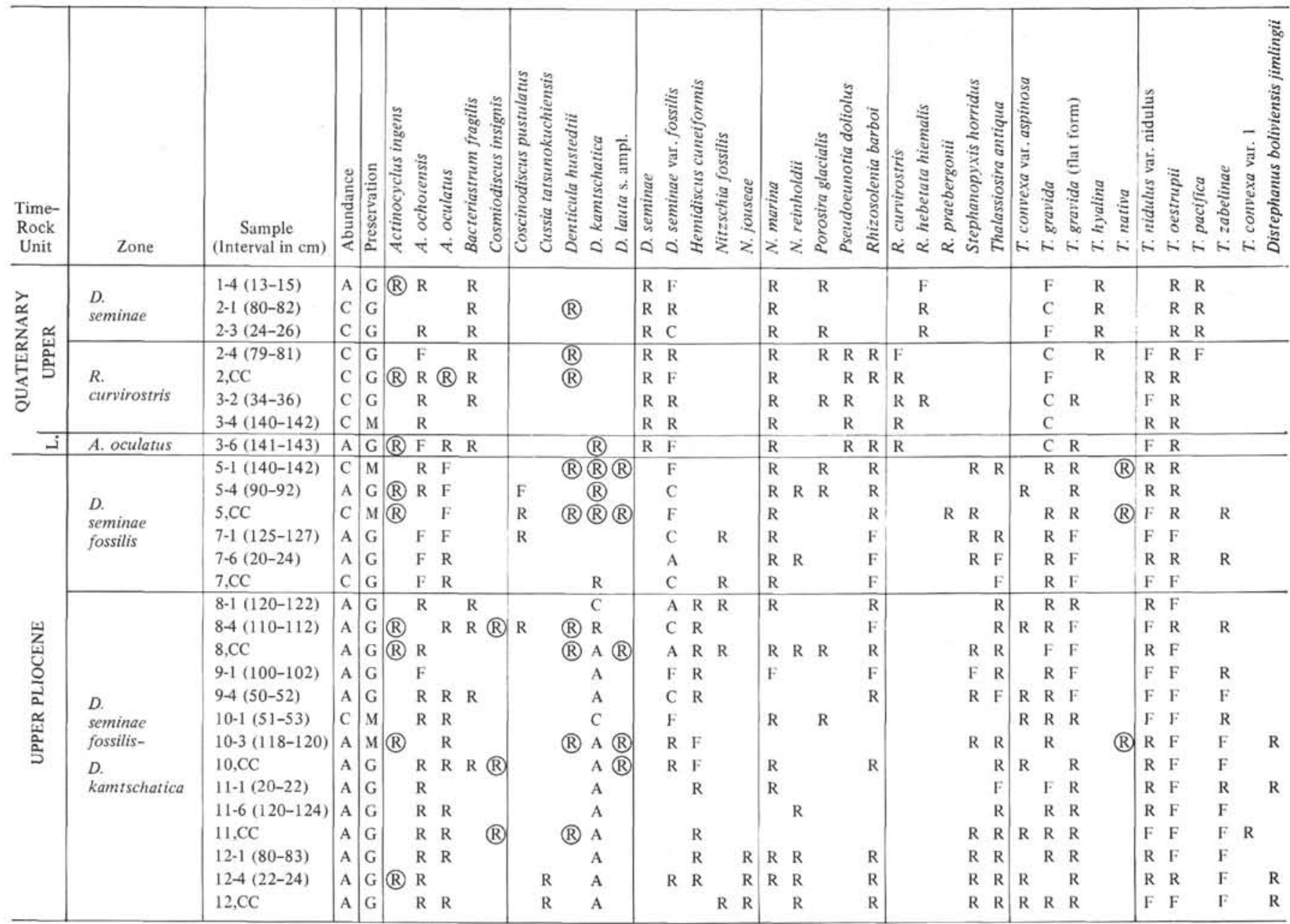

Note: $\mathrm{A}=$ abundant, $\mathrm{C}=$ common, $\mathrm{F}=$ few, $\mathrm{R}=$ rare,$(B=$ reworked. Preservation: $\mathrm{G}=$ good, $\mathrm{M}=$ moderate, $\mathrm{P}=$ poor. 
rence of Cussia tatsunokuchiensis in Sample 438-12-4, $22-24 \mathrm{~cm}(104.7 \mathrm{~m})$, is near the last occurrence of $N$. jouseae, but Koizumi (1977) reports that $C$. tatsunokuchiensis ranges into the overlying Denticula seminae var. fossilis Zone. The occurrence of $C$. tatsunokuchiensis at Site 440 is supportive of its extinction in the upper part of the $D$. seminae var. fossilis-D. kamtschatica Zone.

\section{Hole 438A}

Hole 438 was abandoned because of a medical emergency. Drilling was resumed nearby $\left(40^{\circ} 37.79^{\prime} \mathrm{N}\right.$, $143^{\circ} 14.15^{\prime} \mathrm{E}$; $1558 \mathrm{~m}$ water depth) a few days later in Hole 438A, from which 868.5 meters of lower Miocene through Quaternary sediment was recovered. Diatoms are present throughout Hole 438A, which represents one of the most complete siliceous microfossil reference sections in the North Pacific. Hole 438A was not cored between 4.0 and 23.0 meters (Cores 1 to 2 ) or between 59.0 and 106.5 meters (Cores 5 to 6 ); otherwise, coring was continuous.

The occurrences of selected stratigraphically important diatoms and silicoflagellates in Hole 438A are given in Tables 2 through 8 . The tables divide Hole $438 \mathrm{~A}$ into seven parts from top to bottom, and the occurrences of diatoms and silicoflagellates that are stratigraphically diagnostic within the given intervals are recorded. The stratigraphic ranges of selected diatoms and silicoflagellates in Hole 438A are shown in Figure 4.

The upper Pliocene to upper Quaternary (Cores 1 through 6) duplicates the section cored in nearby Hole 438. Assemblages in Cores 6 and 7 of Hole 438A correlate with the lower parts of Hole 438, as evidenced by the last occurrence of Nitzschia jouseae in Sample 438A-6,CC $(113 \mathrm{~m})$ and the last occurrence of Cussia tatsunokuchiensis in Sample 438A-7,CC (123 m). The common Denticula kamtschatica reported in Sample 438A-5, CC $(57.5 \mathrm{~m})$ comes from a limestone nodule within otherwise soft sediment and probably represents reworking.

The greater part of the $D$. seminae var. fossilis $-D$. kamtschatica Zone at Sites 438 and 440 is characterized by very rare or absent $D$. seminae var. fossilis. Studies at Site 440 suggest that $D$. seminae var. fossilis ranges at least as low as the last occurrence of Thalassiosira nativa. Correlations between Sites 440 and 438 indicate that the last occurrence of $T$. nativa is nearly synchronous in the immediate area, so that the base of the D. seminae var. fossilis Zone may be approximated by the last occurrence of $T$. nativa in Sample 438A-12,CC in Hole 438A.

Thalassiosira nidulus var. delicata, n. var., last occurs in Sample 438A-14,CC (190.3 m), and Actinocyclus oculatus first occurs in Sample 438A-17, CC (215.3 $\mathrm{m})$ within the upper part of Subzone $c$ of the Denticula kamtschatica Zone. Assemblages of Subzone $c$ are characterized by abundant $D$. kamtschatica, common to few Thalassiosira nativa, and intervals of common $T$. zabelinae (Tables 2 and 3 ).

Koizumi (1977) reports the last occurrence of Thalassiosira nativa slightly above the first occurrence of $\mathrm{Ac}$ - tinocyclus oculatus within the middle part of the Denticula seminae var. fossilis-D. kamtschatica Zone in middle latitudes of the North Pacific. Occurrences at Sites 438 and 440 suggest a younger first occurrence of Denticula seminae var. fossilis in the area off northeastern Japan.

The last occurrence of Cosmiodiscus insignis in Sample 438A-28-1, 140-142 cm (316.9 m), marks the top of Subzone $b$ of the D. kamtschatica Zone. Nitzschia jouseae first occurs in Sample 438A-29-5, 10-12 cm (331 $\mathrm{m})$, just below the last occurrence of $C$. insignis. The sediment accumulation rate curve (Figure 5) for Hole 438A suggests that this first occurrence of $N$. jouseae approximates the reported first occurrence of $N$. jouseae (about 4.5 m.y.B.P.) (Burckle, verbal communication, 1978) in the tropical Pacific between the "c" Events of the Gilbert Paleomagnetic Epoch. Burckle and Opdyke (1977) report the first occurrence of Denticula seminae var. fossilis slightly above the first occurrence of $N$. jouseae in the North Pacific and correlate it with the interval between the " $b$ " and " $c$ " Events of the Gilbert. It appears that $D$. seminae var. fossilis has a restricted range in the area of the Leg 57 sites and that the last occurrence of $C$. insignis in Sample 438A-28-1, 140-142 cm, approximates the first occurrence of $D$. seminae var. fossilis elsewhere in the North Pacific. At Site 192, to the north of the Leg 57 sites, Koizumi (1973) records the first occurrence of $D$. seminae var. fossilis slightly above the last occurrence of $C$. insignis.

Coscinodiscus temperei last occurs in Sample 438A$34-1,85-87 \mathrm{~cm}$ (373.3 m), near the base of Subzone $b$ of the Denticula kamtschatica Zone. Other than the presence of rare Cosmiodiscus insignis, the assemblages of Subzone $b$ are very similar to those of Subzone $c$ (Tables 3 and 4$)$.

The last occurrence of Rouxia californica in Sample 438A-35, CC (391.5 mm) marks the top of Subzone $a$ of the D. kamtschatica Zone and approximates the Miocene/Pliocene boundary (Harper, 1977a). The first occurrence of Thalassiosira oestrupii s. str. in Sample 438A-35-5, 135-137 cm $(389.4 \mathrm{~m})$, is coincident with this subzonal boundary. Burckle and Opdyke (1977) correlate the first $T$. oestrupii with the lowermost Gilbert Paleomagnetic Epoch, and it is likely that this datum level lies close to the Miocene/Pliocene boundary of Cita (1975) and Van Couvering and others (1976) in the lowermost reversed event of the Gilbert.

Cussia tatsunokuchiensis also has its first occurrence at the top of Subzone $a$ of the D. kamtschatica Zone in Hole 438A, and the last occurrence of Goniothecium tenue is just below in Sample 438A-36-3, 80-82 cm $(395.3 \mathrm{~m})$. Koizumi (1977) also reports a coincidence of the last occurrences of $R$. californica and $G$. tenue with the first occurrence of $C$. tatsunokuchiensis in the middle-latitude northwestern Pacific. The silicoflagellate Distephanus boliviensis jimlingii first occurs in Sample 438A-37,CC $(405 \mathrm{~m})$ within Subzone $a$. Thalassiosira miocenica (T. usatchevi of Burckle, 1972) last occurs in Sample 438A-38-5, 110-112 cm (417.6 m), where it corresponds with an isolated occurrence of Asterolampra acutiloba. Burckle (1978) correlates the last T. mio- 
TABLE 2

Stratigraphic Occurrence of Selected Diatoms and the Silicoflagellate Distephanus boliviensis jimlingii, Core 438A-1 through Section 438A-15-1, 44-46 cm

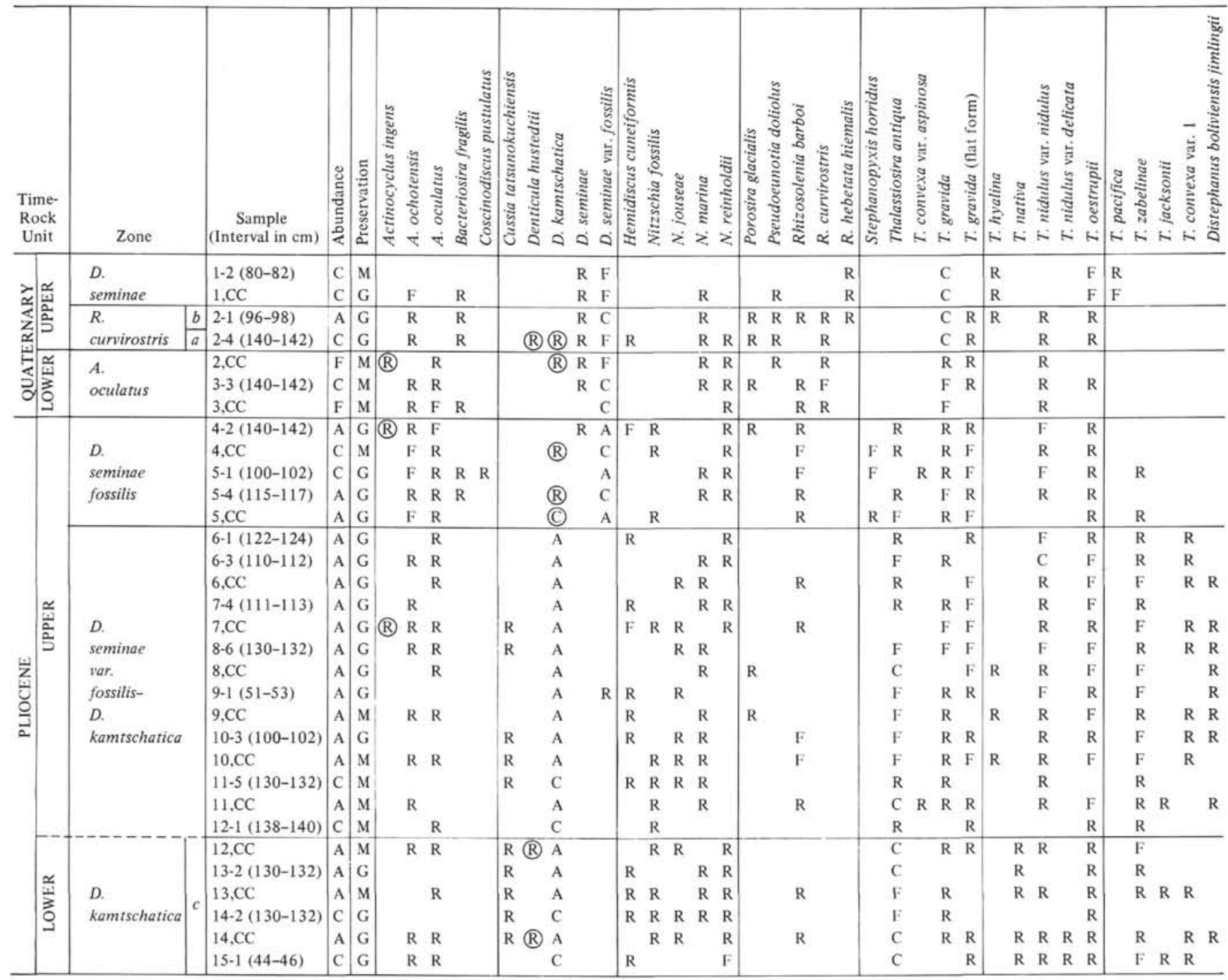

Note: There is a coring gap of 4 to 23 meters between Cores 1 and 2 and 59 to 106.5 meters between Cores 5 and 6 .

cenica with the lower Gilbert Epoch, midway between the lower "c"' Event and the top of Epoch 5 and the last A. acutiloba with the top of Epoch 5. It is possible that $T$. miocenica ranges only as high as the top of Epoch 5 in Hole 438A because of a climatic cooling reported above this level for planktonic foraminifers by Keller (this volume).

The last occurrence of $N$. miocenica in Sample 438A$39, \mathrm{CC}(429.5 \mathrm{~m})$ correlates with the top of the reversed event of Paleomagnetic Epoch 5 (Burckle, 1972, 1978).

The base of the Denticula kamtschatica Zone is marked by the first occurrence of $D$. kamtschatica s. str. in Sample 438A-42-3, 110-112 cm (452.6 m). Specimens resembling $D$. kamtschatica but possessing greater than 6 pseudoseptae in $10 \mu \mathrm{m}$ occur below that level and are referred to as $D$. sp. cf. D. kamtschatica in Tables 4 and 12. Such specimens include $N$. rolandii of Harper (1977b) and of Koizumi (in press).
The first occurrences of $N$. reinholdii, $T$. convexa var. aspinosa, $T$. gravida, $T$. gravida (flat form), $T$. jacksonii, and $T$. nidulus var. delicata all coincide closely with the base of the D. kamtschatica Zone in Hole 438A. The last occurrences of N. pliocena and Synedra jouseana lie immediately below in Sample 438A-42-5, $83-85 \mathrm{~cm}(455.3 \mathrm{~m})$. These occurrences and the last occurrence of $N$. porteri in Sample 438A-43-3, 123-125 cm $(462.2 \mathrm{~m})$, argue that a hiatus spanning the interval from about 5.6 to about 6.7 m.y.B.P. is present in the lower part of Core 42 (Figure 5). A thin $(0.5 \mathrm{~m})$ siltstone layer containing pumice pebbles and overlain by glauconitic sediment in the upper part of Section 4 of Core 42 is a likely position for this hiatus.

The upper part of the $D$. hustedtii Zone above the last occurrence of Coscinodiscus yabei in Sample 438A$46, C C(497.7 \mathrm{~m})$ is assigned to Subzone $b$ of the $D$. hustedtii Zone. Subzone $b$ is characterized by rare $D$. 
TABLE 3

Stratigraphic Occurrence of Selected Diatoms and the Silicoflagellate Distephanus boliviensis jimlingii, Cores 438A-15, CC-438A-29

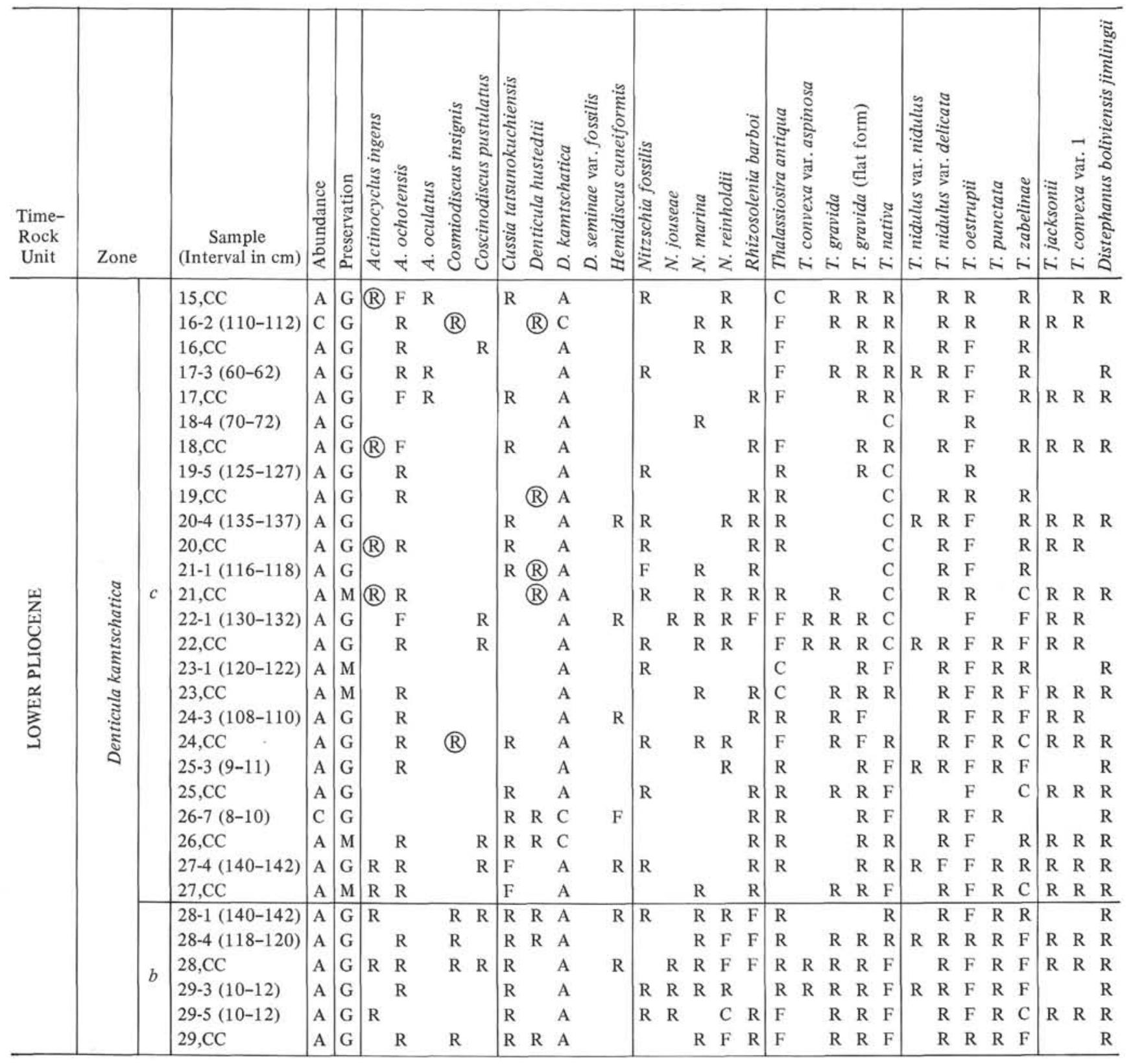

hustedtii without $D$. kamtschatica s. str. but containing $D$. sp. cf. D. kamtschatica, which appears in Sample 438A-45, CC (487.5 m). Denticula sp. cf. D. kamtschatica also ranges into Subzone $b$ in the Bering Sea (Barron, unpublished data).

Other significant events within Subzone $b$ of the $D$. hustedtii Zone include the first occurrences of $N$. miocenica and N. marina in Sample 438A-43-3, 123-125 $\mathrm{cm}(462.2 \mathrm{~m})$; the last occurrence of Thalassionema hirosakiensis in Sample 438A-43-5, 135-137 cm (465.4 $\mathrm{m})$; the last occurrence of Thalassiosira burckliana in Sample 438A-44-3, 120-122 cm (473.7 m); the first occurrence of Cosmiodiscus insignis and the last occurrence of the silicoflagellate Distephanus pseudofibula in Sample 438A-44-5, 71-73 cm (476.2 m); the first occur- rence of $T$. zabelinae s. ampl. in Sample 438A-45, CC $(487.4 \mathrm{~m})$; and the first occurrence of $N$. pliocena in Sample 438A-46-3, 91-93 cm (492.4 m). According to Burckle $(1972,1978)$, the last occurrence of $N$. porteri and the first occurrence of $N$. miocenica correlate with the middle part of Paleomagnetic Epoch 7; the last occurrence of $T$. burckliana correlates with the lower part of Epoch 7; and the last occurrence of Coscinodiscus yabei corrrelates with the middle part of Epoch 8. Burckle (written communication, 1979), however, suggests that the last occurrence of $C$. yabei may be younger in higher latitudes. The sediment accumulation rate curve for Hole 438A (Figure 5) shows that when referenced against other datum levels these tropical datum levels occur at the expected levels in Hole 438A. 
TABLE 4

Stratigraphic Occurrence of Selected Diatoms and the Silicoflagellate Distephanus boliviensis jimlingii, Cores 438A-30-438A-40

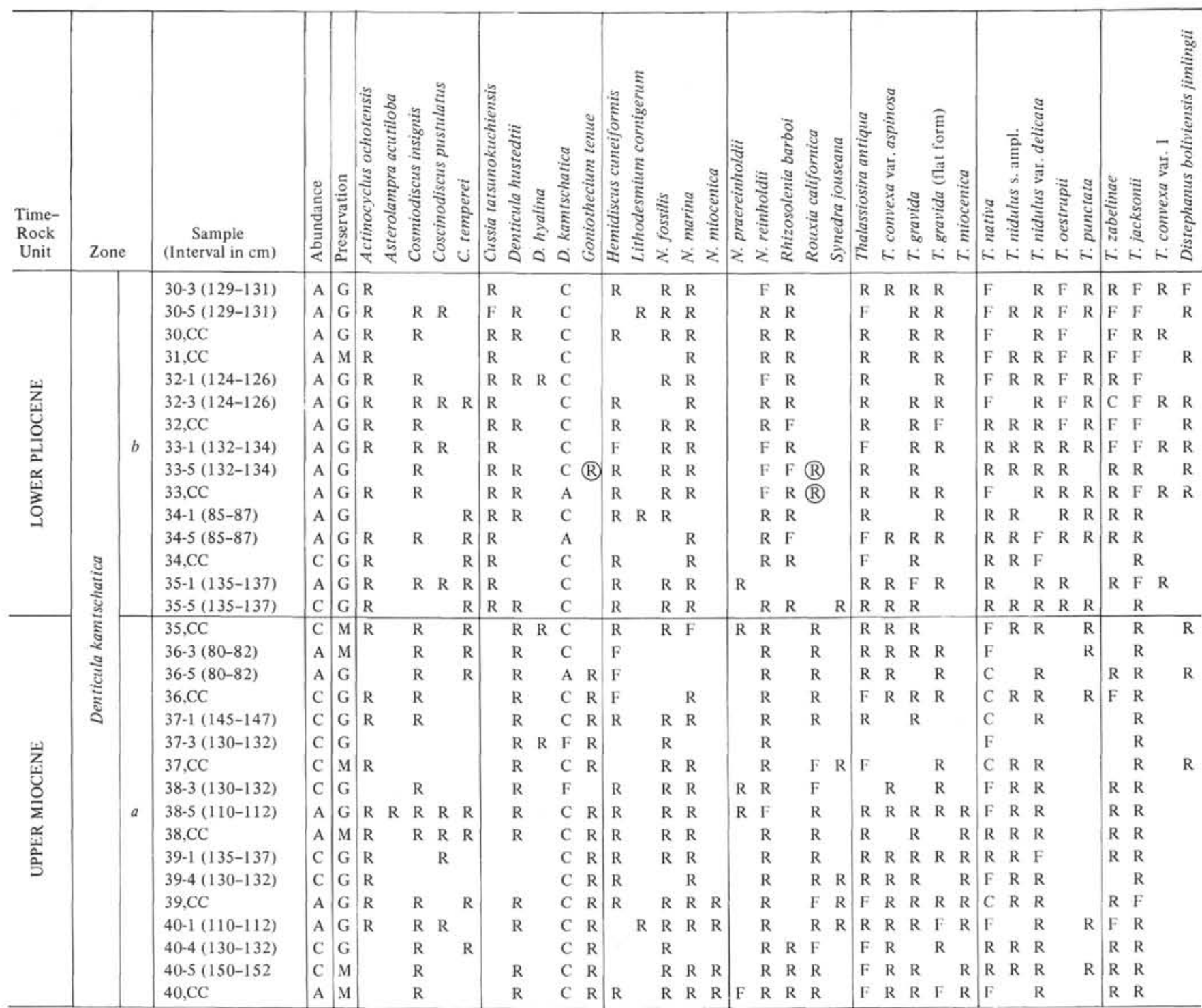

The last occurrences of Thalassionema hirosakiensis and $D$. pseudofibula are useful for correlations with California and the Bering Sea (Barron, 1976; unpublished data). Cosmiodiscus insignis also ranges into Subzone $b$ of the Denticula hustedtii Zone in the Bering Sea (Barron, unpublished data), well below the range reported by Koizumi (1977).

Subzone $a$ of the $D$. hustedtii Zone is characterized by common $D$. hustedtii in its lower part and few to rare $D$. hustedtii in its upper part. The first occurrence of Thalassiosira antiqua in Sample 438A-47-1, 70-72 cm $(498.7 \mathrm{~m})$, lies immediately below the top of this subzone and may be used in California to approximate the boundary. Other significant events within Subzone $a$ of the $D$. hustedtii Zone include the first occurrence of $N$. fossilis in Sample 438A-48,CC (516.6 m); the first consistent occurrence of $T$. burckliana in Sample 438A$49, \mathrm{CC}(525.9 \mathrm{~m})$; the first occurrence of $T$. nidulus $\mathrm{s}$. ampl. in Sample 438A-49-3, 140-142 cm (521.4 m); and the first occurrence of $N$. porteri in Sample 438A-51-1, $105-107 \mathrm{~cm}(537 \mathrm{~m})$. All of these first occurrences fall above the last common occurrence of $D$. hustedtii (in Sample 438A-51,CC [544.8 m]) and may be related to a period of climatic warming reported in the middle part of the upper Miocene in California by Barron (1973). The last occurrences of Coscinodiscus endoi in Sample 438A-52-5, 128-130 cm (552.8 m), and Rhizosolenia miocenica in Sample 438A-53-1, 128-130 cm (556.3 m), lie near the base of the $D$. hustedtii Zone. These diatom events occur in the same sequence at Site 173 (Schrader, 1973) and in the Upper Newport Bay section of southern California (Barron, 1976).

The top of the $D$. hustedtii-D. lauta Zone is marked by the last occurrence of $D$. dimorpha in Sample $438 \mathrm{~A}-55-1,30-32 \mathrm{~cm}(574.3 \mathrm{~m})$. D. lauta apparently has its last occurrence slightly higher in Sample 438A-54-3, $65-67 \mathrm{~cm}(578.2 \mathrm{~m})$; however, D. lauta is commonly reworked into younger sediment in all of the Leg 57 
TABLE 5

Stratigraphic Occurrence of Selected Diatoms and the Silicoflagellate Distephanus pseudofibula, Cores 438A-41-438A-50

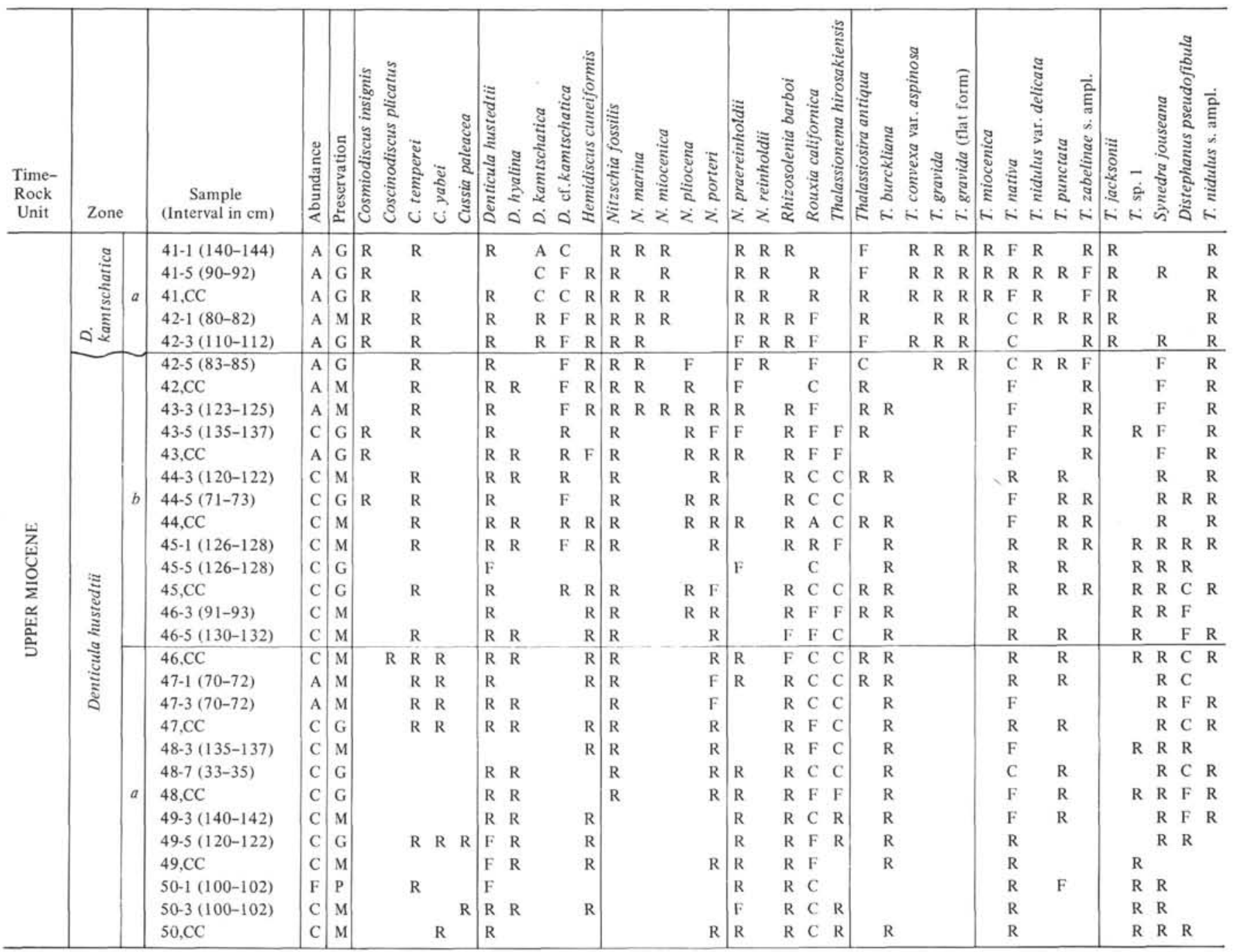

holes and may be confused with $D$. hyalina in a poorly preserved assemblage. For these reasons and the close stratigraphic association of the extinctions of $D$. lauta and $D$. dimorpha noted by Schrader (1973) and Barron (1976), the last occurrence of $D$. dimorpha rather than the last $D$. lauta is used to mark the top of the $D$. hustedtii-D. lauta Zone.

Subzone $d$ of the $D$. hustedtii- $D$. lauta Zone represents the stratigraphic range of $D$. dimorpha s. str. and occurs from Sample 438A-55-1, 30-32 cm $(574.3 \mathrm{~m})$, through Sample 438A-59,CC $(618.4 \mathrm{~m})$. The last occurrence of D. punctata (Sample 438A-56-5, 60-62 cm [590.1 m]), the first occurrence of $T$. nativa (Sample $438 \mathrm{~A}-57-3,115-117 \mathrm{~cm}[597.2 \mathrm{~m}])$, and the first occurrence of Lithodesmium reynoldsii (Sample 438A-58,CC [604.5 m]) lie within Subzone $d$ in Hole 438A. These taxa have similar ranges at Site 173 (Schrader, 1973; Barron, unpublished data), but only the first occurrence of $L$. reynoldsii is within Subzone $d$ in the Upper Newport Bay section in southern California (Barron, 1976).
The interval below Subzone $d$ down to the first occurrence of $R$. barboi in Sample 438A-64-1, 126-128 cm $(660.8 \mathrm{~m})$, is assigned to Subzone $c$ of the D. hustedtii-D. lauta Zone. The sediment accumulation rate curve (Figure 5) for Hole 438A suggests that the middle Miocene/upper Miocene boundary of Ryan and others (1974) lies just below the top of Subzone $c$. Notable datum levels within Subzone $c$ in Hole 438A include the last occurrence of $N$. heteropolica (Sample 438A-60-1, $134-136 \mathrm{~cm}$ [622.8 m]), the last occurrence of $R$. praebarboi (Sample 438A-60,CC [625.2 m]), the first occurrence of the silicoflagellate Distephanus pseudofibula (Sample 438A-61,CC [631.1 m]), and the restricted range of the silicoflagellate Mesocena hexagona (Sample 438A-60,CC [625.2 m]) through Sample 438A$63, \mathrm{CC}[651.2 \mathrm{~m}])$. All of these datums are useful within Subzone $c$ in the Bering Sea (Barron, unpublished data); but the first occurrence of $D$. pseudofibula is within overlying Subzone $d$ at Site 173 (Bukry, 1973b) and in southern California (Barron, 1976), and the last occurrence of $N$. heteropolica is within underlying Subzone $b$ 


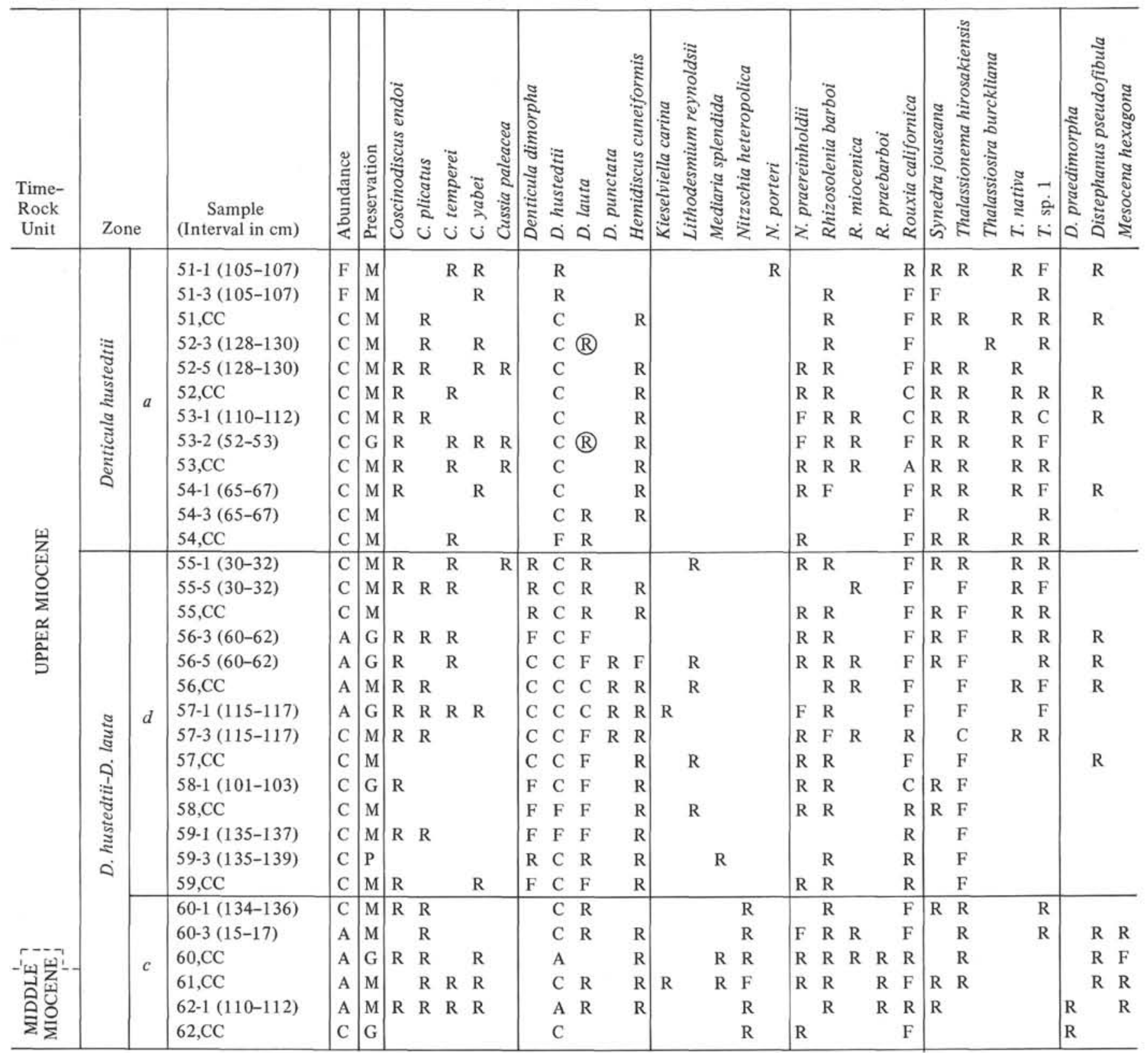

at Site 173 (Schrader, 1973). Hemidiscus cuneiformis s. ampl. first occurs in Sample 438A-63,CC $(651.2 \mathrm{~m})$ slightly above the first occurrence of $R$. barboi, a relationship which occurs at Site 173 off northern California and in the Upper Newport Bay Section in southern California (Figure 1).

Cores 64 and 65 are assigned to Subzone $b$ of the $D$. hustedtii-D. lauta Zone on the basis of the presence of $D$. praedimorpha without $R$. barboi. The last consistent occurrence of Mediaria splendida in Sample 438A-64-3, $36-38 \mathrm{~cm}(662.8 \mathrm{~m})$, coincides closely with the top of this subzone here, at Site 173 (Schrader, 1973), and in southern California (Barron, 1976). Also notable are the first occurrences of $N$. heteropolica (Sample 438A64,CC [668.4 m]), Coscinodiscus temperei (Sample 438A-65-1, 136-137 cm [670.4 m]), and Coscinodiscus yabei (Sample 438A-65,CC [676.1 m]). Nitzschia heteropolica is associated with Subzone $b$ in the Bering Sea (Barron, unpublished data) and at Site 173 (Schrader, 1973), as is the first occurrence of Coscinodiscus temperei.

A hiatus separates Subzones $a$ and $b$ of the $D$. hustedtii-D. lauta Zone between the core catcher of Core 65 and the top of Core 66 (Figure 5). Akiba (written communication, 1977) recognizes a hiatus in the same stratigraphic position in the Ninohe area in nearby northeast Honshu. Elsewhere in the North Pacific, the first occurrence of $C$. yabei is below the first occurrence of $D$. praedimorpha.

Subzone $a$ of the $D$. hustedtii-D. lauta Zones occurs down through Sample 438A-68-1, 101-103 cm (698.5 $\mathrm{m})$, the first occurrence of $D$. hustedtii. The last consis- 
TABLE 7

Stratigraphic Occurrence of Selected Diatoms and the Silicoflagellates Mesocena apiculata curvata and M. hexagona, Cores 438A-63-438A-76

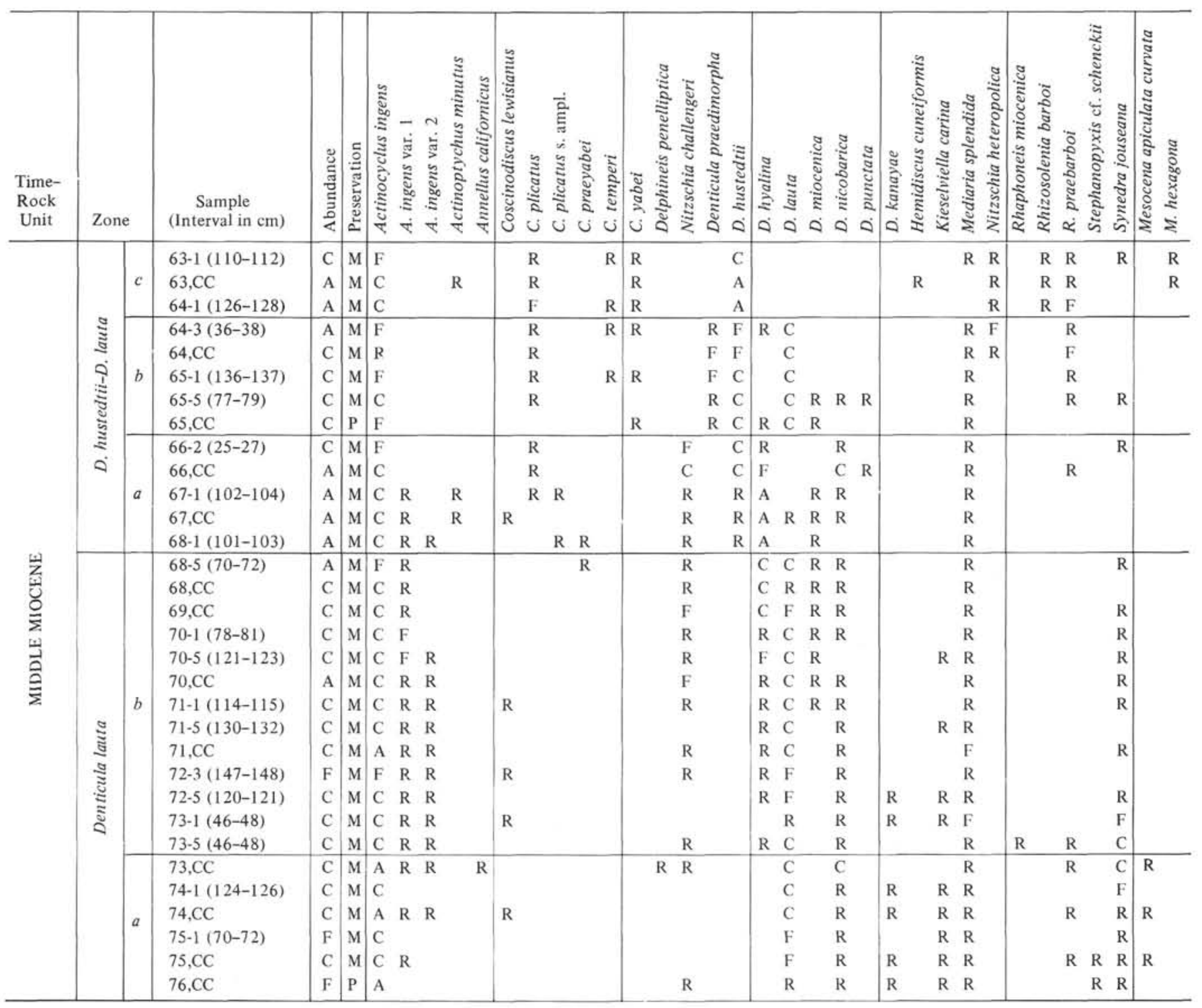

tent occurrences of $D$. nicobarica and $N$. challengeri in Sample 438A-66-2, 25-27 cm (680.3 m), coincide with the truncated top of Subzone $a$ at the hiatus. Within subzone $a, D$. hustedtii becomes dominant uphole over D. hyalina in Sample 438A-66,CC $(681 \mathrm{~m})$. The first occurrence of $C$. plicatus and the last occurrence of $A C$ tinocyclus ingens var. 1 are immediately below in Sample 438A-67-1, 102-104 cm (689 m).

The first dominant appearance of $D$. hustedtii over $D$. lauta and $D$. hyalina is a recognizable diatom event throughout the North Pacific (Koizumi, 1973; Schrader, 1973; Barron, 1976; Koizumi, 1977) and probably corresponds with the first occurrence of $D$. hustedtii in the tropical Pacific. The last occurrence of $A$. ingens var. 1 is immediately below this diatom datum in the Upper Newport Bay section in southern California and in sediments off southern California (Barron, unpublished data).

The interval below the first occurrence of $D$. hustedtii in Sample 438A-68-1, 101-103 cm (698.5 m), down through the first occurrence of D. lauta s. str. in Sample $438 \mathrm{~A}-83, \mathrm{CC}(840.2 \mathrm{~m})$ is assigned to the lower middle Miocene D. lauta Zone. Assemblages are characterized by common to abundant $A$. ingens displaying many different variations in morphology and by common to few $D$. lauta. The first occurrence of $D$. hyalina divides the $D$. lauta Zone into two subzones, Subzone $a$ and Subzone $b$. Relationships in southern California suggest that the last occurrence of Annellus californicus and the last occurrence of the silicoflagellate Mesocena apiculata curvata approximate the first occurrence of $D$. hyalina (Barron, unpublished data). An isolated occurrence of A. californicus in Sample 438A-73,CC (754.5 m) coincides with the last $M$. apiculata curvata and is immediately below the first occurrence of $D$. hyalina in Sample 438A-73-5, 46-48 cm (751.5 m) (Table 7).

Delphineis penelliptica, Kieselviella carina, Rhaphoneis miocenica, Cymatogonia amblyoceras, and Denticula norwegica occur sporadically within Subzone $a$ of 
TABLE 8

Stratigraphic Occurrence of Selected Diatoms and the Silicoflagellate Mesocena apiculata curvata, Cores 438A-77-438A-86

\begin{tabular}{|c|c|c|c|c|c|c|c|c|c|c|c|c|c|c|c|c|c|c|c|c|c|c|c|c|c|}
\hline $\begin{array}{l}\text { Time- } \\
\text { Rock } \\
\text { Unit }\end{array}$ & \multicolumn{2}{|l|}{ Zone } & $\begin{array}{c}\text { Sample } \\
\text { (Interval in cm) }\end{array}$ & 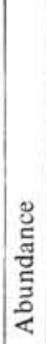 & 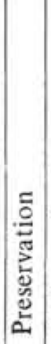 & 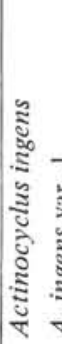 & 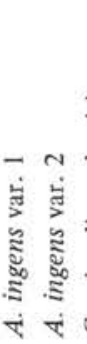 & 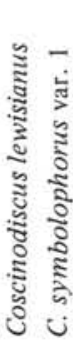 & 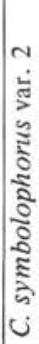 & 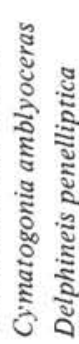 & 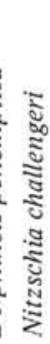 & 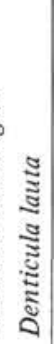 & 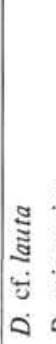 & 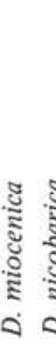 & 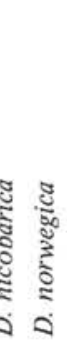 & $\begin{array}{l}0 \\
\frac{3}{3} \\
\overline{3} \\
\frac{3}{3} \\
0\end{array}$ & 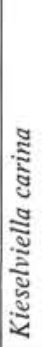 & 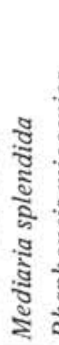 & 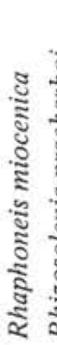 & 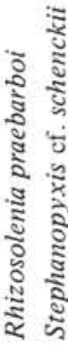 & 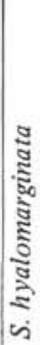 & के & 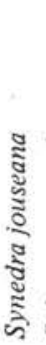 & 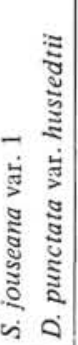 & 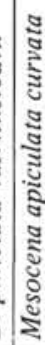 \\
\hline 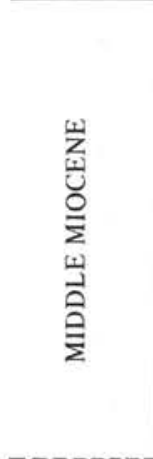 & 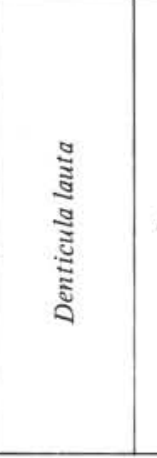 & $a$ & $\begin{array}{l}77-1(81-83) \\
77, \mathrm{CC} \\
78-3(92-94) \\
78, \mathrm{CC} \\
79-1(55-57) \\
79-3(55-57) \\
79-5(56-57) \\
79, \mathrm{CC} \\
80, \mathrm{CC} \\
81, \mathrm{CC} \\
82, \mathrm{CC} \\
83, \mathrm{CC}\end{array}$ & $\begin{array}{l}\text { C } \\
C \\
C \\
C \\
C \\
F \\
C \\
C \\
C \\
C \\
C \\
C\end{array}$ & $\begin{array}{l}\mathrm{M} \\
\mathrm{M} \\
\mathrm{P} \\
\mathrm{M} \\
\mathrm{M} \\
\mathrm{P} \\
\mathrm{P} \\
\mathrm{P} \\
\mathrm{M} \\
\mathrm{M} \\
\mathrm{M} \\
\mathrm{P}\end{array}$ & $\begin{array}{ll}C & F \\
C & R \\
C & \\
C & R \\
C & F \\
F & R \\
C & \\
C & \\
C & R \\
C & \\
F & \\
F & \end{array}$ & $\begin{array}{ll}\mathrm{F} & \mathrm{R} \\
\mathrm{R} & \\
& \mathrm{R} \\
\mathrm{R} & \\
\mathrm{F} & \mathrm{R} \\
\mathrm{R} & \\
\mathrm{R} & \\
\mathrm{R} & \\
& \end{array}$ & $\begin{array}{ll}\mathrm{R} & \\
\mathrm{R} & \\
& \\
\mathrm{R} & \\
\mathrm{F} & \\
\mathrm{R} & \mathrm{R} \\
& \mathrm{R} \\
\mathrm{R} & \mathrm{R} \\
\mathrm{R} & \end{array}$ & & $\begin{array}{l}\mathrm{R} \\
\mathrm{R}\end{array}$ & $\begin{array}{l}\mathrm{R} \\
\mathrm{R} \\
\mathrm{R} \\
\mathrm{R} \\
\mathrm{R} \\
\mathrm{R} \\
\mathrm{R} \\
\mathrm{R} \\
\mathrm{R} \\
\mathrm{R} \\
\mathrm{R}\end{array}$ & $\begin{array}{l}F \\
C \\
F \\
C \\
F \\
R \\
F \\
R \\
C \\
F \\
R \\
R\end{array}$ & $\begin{array}{l}\mathrm{C} \\
\mathrm{R}\end{array}$ & $\begin{array}{rl} & \mathrm{R} \\
& \mathrm{R} \\
& \mathrm{R} \\
\mathrm{R} & \mathrm{R} \\
\mathrm{R}\end{array}$ & $\begin{array}{ll}\mathrm{R} & \mathrm{R} \\
\mathrm{R} & \\
\mathrm{R} & \\
\mathrm{R} & \\
\mathrm{R} & \end{array}$ & $\mathbf{R}$ & $\begin{array}{l}\mathrm{R} \\
\mathrm{R} \\
\mathrm{R} \\
\mathrm{R} \\
\mathrm{R} \\
\mathrm{R} \\
\mathrm{R} \\
\mathrm{R}\end{array}$ & $\begin{array}{l}\mathrm{R} \\
\mathrm{R} \\
\mathrm{R} \\
\mathrm{R} \\
\mathrm{R} \\
\mathrm{R} \\
\mathrm{R} \\
\mathrm{R} \\
\mathrm{R} \\
\mathrm{R} \\
\mathrm{R} \\
\mathrm{R}\end{array}$ & $\begin{array}{lll} & 1 \\
R & 1 \\
& 1 \\
R & 1 \\
& 1 \\
& 1 \\
& 1 \\
R & 1 \\
R & 1 \\
R\end{array}$ & $\begin{array}{ll}\mathrm{R} & \mathrm{R} \\
\mathrm{R} & \mathrm{R} \\
\mathrm{R} & \mathrm{R} \\
\mathrm{R} & \\
\mathrm{F} & \mathrm{R} \\
\mathrm{R} & \mathrm{R} \\
\mathrm{R} & \mathrm{R} \\
\mathrm{R} & \\
\mathrm{R} & \mathrm{R} \\
\mathrm{R} & \mathrm{R} \\
\mathrm{R} & \mathrm{R}\end{array}$ & $\begin{array}{l}\mathrm{R} \\
\mathrm{R}\end{array}$ & $\begin{array}{l}\mathrm{R} \\
\mathrm{R}\end{array}$ & $\begin{array}{l}R \\
R \\
R \\
R \\
R \\
R \\
R \\
R \\
C \\
F \\
F \\
R\end{array}$ & $\mathrm{R}$ & \\
\hline $\begin{array}{l}\text { LOWER } \\
\text { MIOCENE }\end{array}$ & \multicolumn{2}{|c|}{$\begin{array}{l}\text { Actinocyclus } \\
\text { ingens }\end{array}$} & $\begin{array}{l}84, \mathrm{CC} \\
85, \mathrm{CC} \\
86, \mathrm{CC}\end{array}$ & $\begin{array}{l}\text { F } \\
\text { C } \\
\text { F }\end{array}$ & $\begin{array}{l}\mathrm{P} \\
\mathrm{M} \\
\mathrm{P}\end{array}$ & $\begin{array}{l}\text { F } \\
F \\
F\end{array}$ & 1 & $\begin{array}{ll}\mathrm{R} & \\
& \mathrm{R} \\
& \mathrm{R}\end{array}$ & $\begin{array}{l}\mathrm{R} \\
\mathrm{R}\end{array}$ & $\mathrm{R}$ & & & $\begin{array}{l}\mathrm{F} \\
\mathrm{C} \\
\mathrm{R}\end{array}$ & . & R & \begin{tabular}{l|}
$R$ \\
$R$ \\
$R$
\end{tabular} & $\begin{array}{l}\mathrm{R} \\
\mathrm{R} \\
\mathrm{R}\end{array}$ & $\begin{array}{l}\mathrm{R} \\
\mathrm{R} \\
\mathrm{R}\end{array}$ & $\begin{array}{l}\mathrm{R} \\
\mathrm{R}\end{array}$ & $\begin{array}{ll} & \mathrm{R} \\
& \mathrm{R} \\
\mathrm{R} & \mathrm{R}\end{array}$ & $\begin{array}{l}\mathrm{R} \\
\mathrm{R} \\
\mathrm{R}\end{array}$ & $R$ & $\begin{array}{l}\mathrm{R} \\
\mathrm{R} \\
\mathrm{R}\end{array}$ & & \\
\hline
\end{tabular}

the $D$. lauta Zone. With the exception of $K$. carina, all of these species are present in Subzone $a$ in southern California (Barron, unpublished data). D. kanayae of Akiba (1977) has its last occurrence in Sample 438A-72-5, $120-121 \mathrm{~cm}(742.7 \mathrm{~m})$, in the lowermost part of Subzone $b$ and occurs rarely and sporadically down through Subzone $a$. The lower part of Subzone $a$ contains the apparent first occurrence of $A$. ingens var. 1 in Sample 438A$80, \mathrm{CC}(817.5 \mathrm{~m})$ and is characterized by varied forms of Coscinodiscus symbolophorus and of the genus Stephanopyxis (S. sp. cf. S. schenckii, $S$. hyalomarginata, and $S$. spp.) (Table 8). N. challengeri first occurs in Sample 438A-84,CC $(857.3 \mathrm{~m})$ near the first occurrence of $D$. lauta s. str. (Sample 438A-83,CC).

The upper lower Miocene $A$. ingens Zone is present from Sample 438A-84, CC through Sample 438A-86,CC $(868.6 \mathrm{~m})$, the base of the hole. Diatom assemblages are similar to those of the lower part of Subzone $a$ of the $D$. lauta Zone and are better characterized in Hole 438B, where more of the zone is represented.

\section{Hole 438B}

Hole $438 \mathrm{~B}\left(40^{\circ} 37.80^{\prime} \mathrm{N}, 143^{\circ} 14.80^{\prime} \mathrm{E} ; 1564.5 \mathrm{~m}\right.$ water depth) extends the stratigraphic record at Site 438 to 1040.7 meters, where lower Miocene sediment of the Actinocyclus ingens Zone was recovered. Diatoms are generally common, and preservation is moderate to poor above Core $9(900.3 \mathrm{~m})$. Below that level, diatoms become few to rare and preservation is usually poor.

Spot coring above 853.3 meters (Cores 1 through 3 ) provides correlation with the section cored in Hole 438A. Sample 438B-1,CC (567.5 m) contains Coscino- discus endoi without Denticula lauta and correlates with the lower part of Subzone $a$ of the D. hustedtii Zone in Hole 438A in the interval from Sample 438A-52-5, 128$130 \mathrm{~cm}(552.7 \mathrm{~m})$, through Sample 438A-54-1, 65-67 cm $(565 \mathrm{~m})$. The silicoflagellates Distephanus pseudofibula and Mesocena hexagona in Sample 438B-2,CC (667 m) occur together in the lower part of Subzone $c$ of the Denticula hustedtii-D. lauta Zone within an interval from Sample 438A-60-3, 15-17 cm (626.1 m), through Sample $438 \mathrm{~A}-61, \mathrm{CC}(631 \mathrm{~m})$. The presence of $D$. lauta, $D$. kanayae, and Kieselviella carina in Sample 438B-3-3, 28-30 cm (789.3 m), argues for correlation with Subzone $a$ of the $D$. lauta Zone within the interval of Cores 73 through 79 of Hole $438 \mathrm{~A}$. These data suggest that stratigraphic levels within the Miocene of Hole 438B are about 25 to 30 meters lower than they are in Hole 438A.

The occurrences of stratigraphically diagnostic diatoms and the silicoflagellate $M$. apiculata curvata in the continuously cored interval (Cores 4 through 23) of Hole 438B are given in Table 9. Cores 17 through 21 and Core 24, at the base of the hole, are barren of diatoms.

Cores 4 and 5 of Hole 438B correlate with Subzone $a$ of the D. lauta Zone in Hole 438A. As in Hole 438A, the first occurrence of $D$. lauta s. str. in Sample 438B-5, CC $(864.2 \mathrm{~m})$ corresponds closely with the first occurrence of Nitzschia challengeri in Sample 438B-6-1, 16$19 \mathrm{~cm}(872.3 \mathrm{~m})$.

The upper lower Miocene $A$. ingens Zone is present from Sample 438B-6-1, 16-19 cm, through Sample 438B23, CC $(1,036.1 \mathrm{~m})$. C. lewisianus and $C$. endoi first occur in Sample 438B-9-1, 85-87 cm (901.2 m). D. kanayae becomes a consistent mernber of the assemblage 


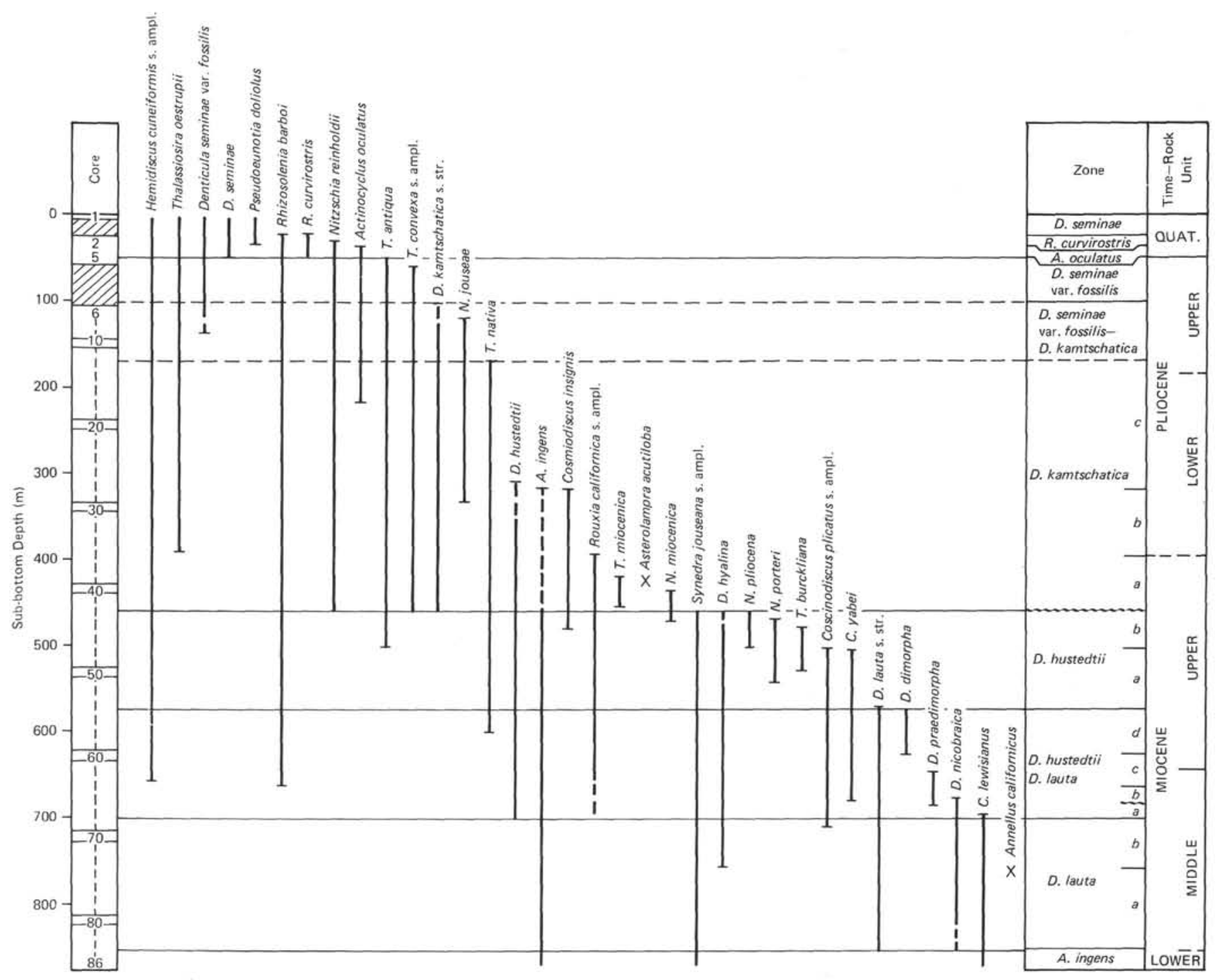

Figure 4. Stratigraphic ranges of selected diatoms in Hole 438A. (Cross-hatched interval was not recovered.)

immediately below in Sample 438B-9,CC (903.8 m). Specimens referred to as $D$. sp. cf. D. lauta in Tables 9 and 10 (Plate 1, Figures 13, 14) are present down through Core 10 but are more common in Core 5 near the first occurrence of $D$. lauta s. str. D. ikebei of Akiba (1977) last occurs in Sample 438B-11,CC (921.4 m), and C. sp. aff. C. marginatus of Schrader (1976) and Thalassiosira sp. 2 have last occurrences in Core 12. Other diatoms characteristic of the $A$. ingens Zone in Hole 438B include varieties of $C$. symbolophorus, $K$. carina, Mediaria splendida, Rhaphoneis miocenica, Stephanopyxis spp., and Synedra jouseana (Table 9). This upper lower Miocene interval is poorly known in the North Pacific, but sediments assignable to the $A$. ingens Zone have been dredged by the U.S. Geological Survey in the Bering Sea and off southern California (Barron, unpublished data). Hole 438B was abandoned owing to poor hole conditions.

\section{Site 439}

Site $439\left(40^{\circ} 37.61^{\prime} \mathrm{N}, 143^{\circ} 18.63^{\prime} \mathrm{E} ; 1656 \mathrm{~m}\right.$ water depth) was drilled to complete the study objectives not met at Site 438 . The probable acoustic basement, a wellindurated, silicified claystone of Late Cretaceous age, was reached in Core $37(1145.5 \mathrm{~m})$, and drilling was terminated soon thereafter in Core $39(1157.5 \mathrm{~m})$. This claystone unit is unconformably overlain by a lowermost Miocene dacite conglomerate (Core 32, Section 2, through Core 37, Section 1), and this in turn is overlain by lower Miocene sandstone and siltstone (Core 22, Section 2, through Core 32, Section 1). Diatoms are restricted to the overlying lower Miocene and younger section (Cores 1 through 20); however, they are rare and poorly preserved below Core $9(897.0 \mathrm{~m})$.

Spot coring (Cores 1 through 4) allows correlation with nearby Hole 438A. Sample 439-1, CC (499 m) con- 


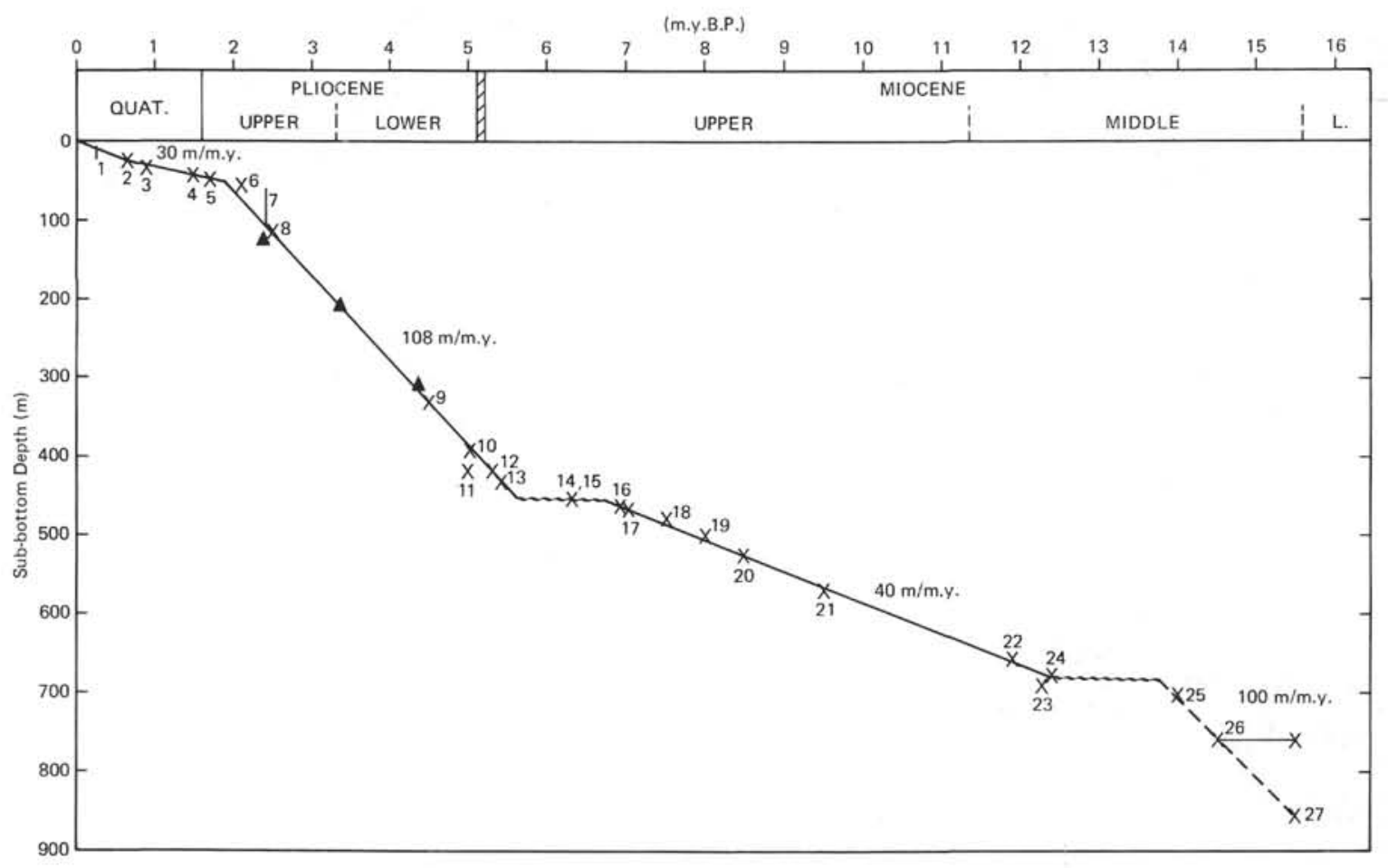

Figure 5. Sediment accumulation rate curve calculated for Hole $438 \mathrm{~A}$ using diatom datum levels listed below. (PM = Paleomagnetic boundaries in Hole 438A (Hall et al., this volume): Gauss/ Matuyama $=120 \mathrm{~m}$; Gauss $/$ Gilbert $=210 \mathrm{~m}$; top of upper " $\mathrm{c}$ " Event of Gilbert $=310 \mathrm{~m}$. Diatom datums: 1 = last Rhizosolenia curvirostris, 2 = last Nitzschia reinholdii, 3 = last Actinocyclus oculatus, $4=$ first $\mathrm{R}$. curvirostris, $5=$ last Thalassiosira antiqua, $6=$ last $\mathrm{T}$. convexa, $7=$ last common Denticula kamtschatica, $8=$ last $\mathrm{N}$. jouseae, $9=$ first $\mathrm{N}$. jouseae, $10=$ first $\mathrm{T}$. oestrupii, 11 $=$ last $\mathrm{T}$. miocenica, $12=$ last Asterolampra acutiloba, $13=$ last $\mathrm{N}$. miocenica, $14=$ first $\mathrm{N}$. reinholdii, $15=$ first $\mathrm{D}$. kamtschatica, $16=$ last $\mathrm{N}$. porteri, $17=$ first $\mathrm{N}$. miocenica, $18=$ last $\mathrm{T}$. burckliana, $19=$ last Coscinodiscus yabei, $20=$ first $\mathrm{T}$. burckliana, $21=$ last $\mathrm{D}$. lauta, $22=$ first Hemidiscus cuneiformis, $23=$ last $\mathrm{C}$. lewisianus, $24=$ last $\mathrm{D}$. nicobarica, $25=$ first $\mathrm{D}$. hustedtii, 26 = range Annellus californicus, $27=$ first D. lauta s. str. See Table 14 for absolute ages of datum levels. Arrow indicates that the last T. nativa, at 166 meters in Hole 438A, has an estimated age of 2.95 m.y.B.P.)

tains the diatom Thalassiosira antiqua and the silicoflagellate Distephanus pseudofibula, an overlap that is restricted to the interval from Sample 438A-44-5, 71-73 $\mathrm{cm}(476.2 \mathrm{~m})$, through Sample 438A-47-1, 70-72 cm (498.7 m) (Subzone $b$ of the Denticula hustedtii Zone). Sample 439-2,CC (556.6 m), which was cored over 50 meters below Core 1, contains the same diatom assemblage as Sample 439-1,CC, and downhole contamination is a possibility. The presence of Rhizosolenia barboi, $R$. praebarboi, and the silicoflagellate Distephanus pseudofibula in Sample 439-3,CC (649 m) argues for correlation with Cores 60 or 61 of Hole 438A (621.5$640.5 \mathrm{~m}$ ) (Subzone $c$ of the Denticula hustedtii-D. lauta Zone). Denticula lauta, D. kanayae, and Delphineis penelliptica in Sample 439-4,CC (749.3 m) occur within Subzone $a$ of the $D$. lauta Zone within the interval from Cores 72 through 79 in Hole 438A. These data suggest that stratigraphic levels in the Miocene of Hole 439 are about 10 to 20 meters lower than they are in Hole 438A.

Continuous coring in Hole 439 began with Core 5 at $849.5 \mathrm{~m}$. Diatoms were present, although they were generally rare and poorly preserved through Core 20 . Below
Core 20 , no more than one or two specimens were observed on a microscope slide. These were usually specimens of the long-ranging, robust species, Coscinodiscus marginatus, and may represent contamination.

Sample $439-5, C C(852.1 \mathrm{~m})$ is assigned to Subzone $a$ of the D. lauta Zone; and although Sample 439-6,CC $(859.1 \mathrm{~m})$ is barren, Samples 439-7,CC (874.5 m) through 439-11,CC $(910.8 \mathrm{~m})$ correlate with the upper part of the Actinocyclus ingens Zone in Hole 438B. The presence of C. endoi and C. lewisianus in Sample 439-11,CC suggests correlation with the interval including Cores 6 through 8 and Sample 438B-9-1, 85-87 $\mathrm{cm} \mathrm{(872.1} \mathrm{to}$ $901.2 \mathrm{~m}$ ), in Hole 438B.

Below this interval in Hole 439, Cores 12 through 20 contain lower Miocene diatoms that are older than the $A$. ingens Zone. It is probable that a hiatus between Cores 11 and 12 of Hole 439 removes the lower part of the $A$. ingens Zone represented in Hole 438B.

The poorly preserved diatom assemblage of Cores 12 through 20 resembles the lower Miocene diatom assemblage reported at Site 348 in the Norwegian Sea by Schrader and Fenner (1976). Species observed include 
TABLE 9

Stratigraphic Occurrence of Selected Diatoms and the Silicoflagellate Mesocena apiculata curvata, Cores 438B-4-438B-23

\begin{tabular}{|c|c|c|c|c|c|c|c|c|c|c|c|c|c|c|c|c|c|c|c|c|c|c|}
\hline $\begin{array}{l}\text { Time- } \\
\text { Rock } \\
\text { Unit }\end{array}$ & Zone & & $\begin{array}{c}\text { Sample } \\
\text { (Interval in } \mathrm{cm} \text { ) }\end{array}$ & 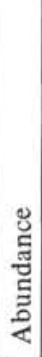 & 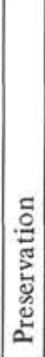 & 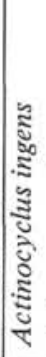 & 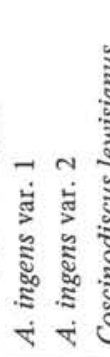 & 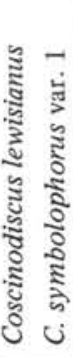 & 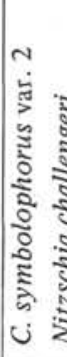 & 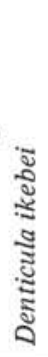 & 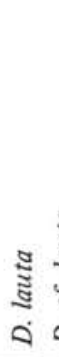 & 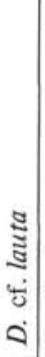 & 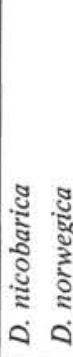 & 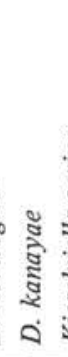 & 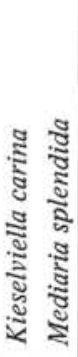 & 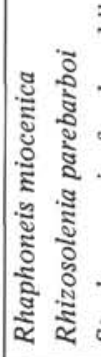 & 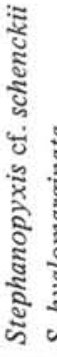 & 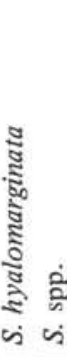 & 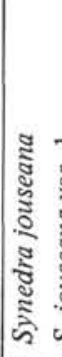 & 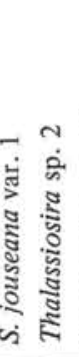 & 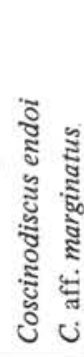 & 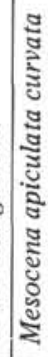 \\
\hline 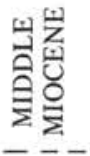 & $\frac{\Xi}{3}$ & $a$ & $\begin{array}{l}4-1(92-94) \\
4, \mathrm{CC} \\
5-1(87-89) \\
5, \mathrm{CC}\end{array}$ & $\begin{array}{l}\mathrm{C} \\
\mathrm{C} \\
\mathrm{C} \\
\mathrm{C}\end{array}$ & $\begin{array}{l}\mathrm{M} \\
\mathrm{M} \\
\mathrm{M} \\
\mathrm{M}\end{array}$ & $\begin{array}{l}\mathrm{C} \\
\mathrm{F} \\
\mathrm{F} \\
\mathrm{C}\end{array}$ & R R F & $\mathrm{R}$ & $\begin{array}{l}\mathrm{P} \\
\mathrm{R} \\
\mathrm{R} \\
\mathrm{R}\end{array}$ & & $\begin{array}{l}\mathrm{C} \\
\mathrm{F} \\
\mathrm{R} \\
\mathrm{R}\end{array}$ & $\begin{array}{l}\mathrm{R} \\
\mathrm{C} \\
\mathrm{C}\end{array}$ & $\begin{array}{l}\mathrm{R} \\
\mathrm{R}\end{array}$ & $\begin{array}{l}\mathrm{R} \\
\mathrm{R}\end{array}$ & $\begin{array}{ll}R & R \\
R & R \\
R & R \\
R & R\end{array}$ & $\begin{array}{l}\mathrm{R} \\
\mathrm{R} \\
\mathrm{R} \\
\mathrm{R}\end{array}$ & $\begin{array}{l}\mathrm{R} \\
\mathrm{R} \\
\mathrm{R} \\
\mathrm{R}\end{array}$ & $\begin{array}{ll}\mathrm{R} & \mathrm{R} \\
& \mathrm{R} \\
\end{array}$ & $\begin{array}{l}\mathrm{R} \\
\mathrm{R} \\
\mathrm{R} \\
\mathrm{R} \\
\end{array}$ & & $\begin{array}{l}\mathrm{R} \\
\mathrm{R} \\
\mathrm{R} \\
\mathrm{R}\end{array}$ & $\mathrm{R}$ \\
\hline 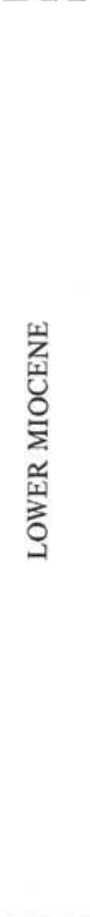 & 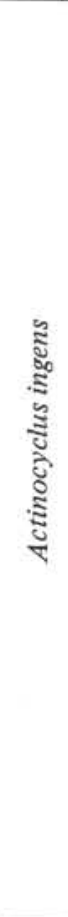 & & $\begin{array}{l}6-1(16-19) \\
6, \mathrm{CC} \\
7-1(128-130) \\
7, \mathrm{CC} \\
8-1(90-92) \\
8, \mathrm{CC} \\
9-1(85-87) \\
9, \mathrm{CC} \\
10-1(9-10) \\
11-1(60-61) \\
11, \mathrm{CC} \\
12-1(81-82) \\
12, \mathrm{CC} \\
13-1(68-70) \\
13, \mathrm{CC} \\
14, \mathrm{CC} \\
15-2(61-62) \\
15, \mathrm{CC} \\
16-2(82-84) \\
16, \mathrm{CC} \\
\text { barren } \\
22-1(108-110) \\
22, \mathrm{CC} \\
23, \mathrm{CC}\end{array}$ & $\begin{array}{l}R \\
C \\
C \\
C \\
C \\
F \\
F \\
R \\
R \\
R \\
F \\
F \\
F \\
F \\
F \\
C \\
R \\
R \\
R \\
F\end{array}$ & $\begin{array}{l}\mathrm{P} \\
\mathrm{P} \\
\mathrm{P} \\
\mathrm{M} \\
\mathrm{M} \\
\mathrm{P} \\
\mathrm{P} \\
\mathrm{P} \\
\mathrm{P} \\
\mathrm{P} \\
\mathrm{M} \\
\mathrm{P} \\
\mathrm{P} \\
\mathrm{P} \\
\mathrm{P} \\
\mathrm{P} \\
\mathrm{P} \\
\mathrm{P} \\
\mathrm{P} \\
\mathrm{P}\end{array}$ & $\begin{array}{l}F \\
F \\
F \\
F \\
F \\
F \\
F \\
R \\
R \\
R \\
R \\
R \\
R \\
R \\
R \\
R \\
R \\
R \\
R \\
R \\
R\end{array}$ & R & $\begin{array}{ll}\mathrm{R} & \mathrm{R} \\
\mathrm{R} & \\
& \mathrm{R} \\
& \mathrm{F} \\
& \mathrm{R} \\
& \\
\mathrm{R} & \\
& \mathrm{R} \\
& \mathrm{R} \\
& \mathrm{R} \\
\mathrm{R} & \mathrm{R} \\
\mathrm{R} & \mathrm{R} \\
\mathrm{R} \\
\mathrm{R} \\
\mathrm{R} \\
\mathrm{R} \\
\\
\mathrm{R}\end{array}$ & $\begin{array}{l}\mathrm{R} \\
\mathrm{R}\end{array}$ & $\begin{array}{l}\mathrm{R} \\
\mathrm{R} \\
\mathrm{R} \\
\mathrm{R} \\
\mathrm{R} \\
\mathrm{R} \\
\mathrm{R}\end{array}$ & , & \begin{tabular}{l|}
$F$ \\
$R$ \\
$R$ \\
$R$ \\
$R$ \\
$R$ \\
$R$ \\
$R$ \\
$R$
\end{tabular} & $\begin{array}{ll} & \mathrm{R} \\
& \mathrm{R} \\
& \mathrm{R} \\
& \\
\mathrm{R} & \end{array}$ & $\begin{array}{l}\text { R } \\
\mathrm{R} \\
\mathrm{R} \\
\mathrm{R} \\
\mathrm{R} \\
\mathrm{R} \\
\mathrm{F} \\
\mathrm{F} \\
\mathrm{R} \\
\mathrm{R} \\
\mathrm{R} \\
\mathrm{R}\end{array}$ & $\begin{array}{lr}R & R \\
& R \\
R & \\
R & \\
F & R \\
R & \\
R & \\
& \\
& \\
R & \\
R & \\
R & \\
R & \\
R & \\
R & R\end{array}$ & $\begin{array}{ll}\mathrm{R} & \\
\mathrm{R} & \\
\mathrm{R} & \\
\mathrm{R} & \mathrm{R} \\
& \\
\mathrm{R} & \mathrm{R} \\
\mathrm{R} & \\
& \\
\mathrm{R} & \end{array}$ & $\begin{array}{ll}\mathrm{R} & \mathrm{l} \\
\mathrm{R} & \mathrm{P} \\
\mathrm{R} \\
\mathrm{R} \\
\mathrm{R} \\
\mathrm{R} \\
\mathrm{R} \\
\mathrm{R} \\
\mathrm{R} & \mathrm{F} \\
\mathrm{R} \\
\mathrm{R} & \mathrm{I} \\
\mathrm{R} \\
\mathrm{R} \\
\mathrm{R} \\
\mathrm{F} \\
\mathrm{F} \\
\mathrm{R} \\
\mathrm{R} \\
\mathrm{R} \\
\mathrm{F} \\
\\
\mathrm{R}\end{array}$ & $\begin{array}{ll}\mathrm{R} & \\
\mathrm{R} & \\
& \\
& \mathrm{R}\end{array}$ & $\begin{array}{l}\mathrm{R} \\
\mathrm{R} \\
\mathrm{R} \\
\mathrm{R} \\
\mathrm{R} \\
\mathrm{F} \\
\mathrm{R} \\
\mathrm{R} \\
\mathrm{R} \\
\mathrm{R} \\
\mathrm{R} \\
\mathrm{R}\end{array}$ & $\begin{array}{l}\mathrm{R} \\
\mathrm{R} \\
\mathrm{R} \\
\mathrm{R}\end{array}$ & $\begin{array}{l}\mathrm{R} \\
\mathrm{R} \\
\mathrm{R} \\
\mathrm{R} \\
\mathrm{R} \\
\mathrm{R} \\
\mathrm{R} \\
\mathrm{R} \\
\mathrm{R}\end{array}$ & $R$ \\
\hline
\end{tabular}

Note: Cores 17 through 21 are barren of diatoms.

C. symbolophorus varieties, Synedra jouseana var. 1 (large form), Cestodiscus spp., T. fraga, $T$. spinosa, $T$. spinosa var. aspinosa, and $T$. spumellaroides. These taxa and the lack of Oligocene diatoms argue strongly for an early Miocene age.

\section{Site 440}

Site $440\left(39^{\circ} 44.13^{\prime} \mathrm{N}, 143^{\circ} 55.74^{\prime} \mathrm{E}\right.$; $4509 \mathrm{~m}$ water depth) was drilled on a midslope terrace of the Japan Trench landward wall to help determine the point of transition from continental to oceanic crust. A thick, nonfolded section of upper Miocene to Quaternary continental slope sediment showing no evidence of accretion was recovered from the composite of the three holes (Holes 440, 440A, and 440B) cored at this site.

Preservation of diatoms is good to moderate down through Core $38(497.0 \mathrm{~m})$ of Hole $440 \mathrm{~B}$, poor to moderate between Cores $39(500.5 \mathrm{~m})$ and $60(705 \mathrm{~m})$ of
Hole 440B, and poor to the base of Hole 440B in Core $71(814 \mathrm{~m})$. Diatoms are common to abundant down to a depth of 497 meters, few to common between 500 and 733 meters, and generally rare below that level.

The occurrences of selected diatoms and silicoflagellates in the section cored at Site 440 are given in Tables 10 through 12 . The stratigraphic ranges of diagnostic diatoms and silicoflagellates in this section are shown in Figure 6.

Cores 1 through 5 of Hole 440 are placed in the uppermost Quaternary Denticula seminae Zone. Reworked earlier Pleistocene diatoms such as Nitzschia fossilis, $N$. reinholdii, Rhizosolenia barboi, $R$. curvirostris, and Thalassiosira nidulus var. nidulus occur in Cores 1 and 2 of Hole 440 within a pebble-rich sediment. As at Site 438 , the apparent last occurrences of $R$. curvirostris, $R$. barboi, and Thalassiosira nidulus var. nidulus in Sample 440-6,CC (52 m) mark the top of the $R$. curvirostris 
TABLE 10

Stratigraphic Occurrence of Selected Diatoms and the Silicoflagellate Mesocena quadrangula, Holes 440, 440A, and Cores 440B-1-440B-18

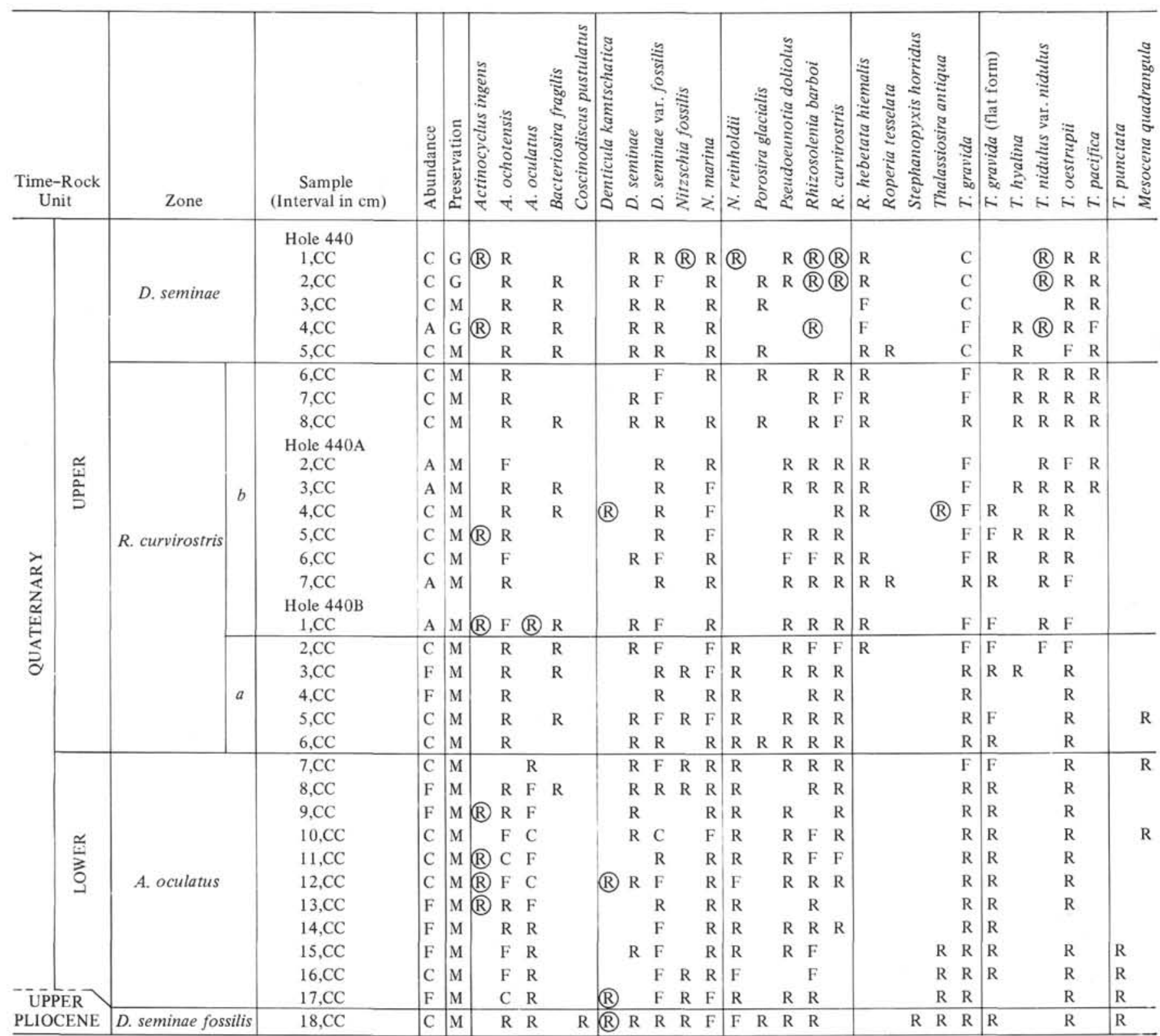

Note: Holes $440,440 \mathrm{~A}$, and $440 \mathrm{~B}$ comprise a composite section with no overlap.

Zone. The $R$. curvirostris Zone is divided into two subzones, Subzone $a$ and Subzone $b$, by the last occurrence of $N$. reinholdii in Sample 440B-2,CC (149.3 m). The younger subzone, Subzone $b$, contains the first occurrence of $T$. pacifica (Coscinodiscus excentricus var. leasareolatus of Koizumi, 1973) in Sample 440A-3,CC ( $96 \mathrm{~m})$, and the last occurrence of $T$. gravida (flat form) in Sample 440A-4,CC (104 m). The first occurrence of $R$. hebetata f. hiemalis in Sample 440B-2,CC (149.3 m) and the last occurrence of $N$. fossilis in Sample 440B-3,CC $(168 \mathrm{~m})$ lie near the top of Subzone $a$. Also notable is the probable last occurrence of the silicoflagellate Mesocena quadrangula in Sample 440B-5,CC (187 m).
The $T$. pacifica, $T$. gravida (flat form), and $R$. hebetata f. hiemalis datums occur in the same sequence within the $R$. curvirostris Zone at Site 438, a relationship that suggests their value for local correlation. The last occurrences of $N$. fossilis and $M$. quadrangula appear to approximate closely their last occurrences in the tropical Pacific (Burckle, 1977; Barron, in press).

The top of the lower Quaternary Actinocyclus oculatus Zone is placed in Core $7(204 \mathrm{~m})$ of Hole $440 \mathrm{~B}$ at the last occurrence of the nominate species. Rhizosolenia curvirostris has its first occurrence near the base of the A. oculatus Zone in Sample 440B-14,CC $(272.5 \mathrm{~m})$. The base of the $A$. oculatus Zone apparently corresponds 
TABLE 11

Stratigraphic Occurrence of Selected Diatoms, Cores 440B-18-440B-48

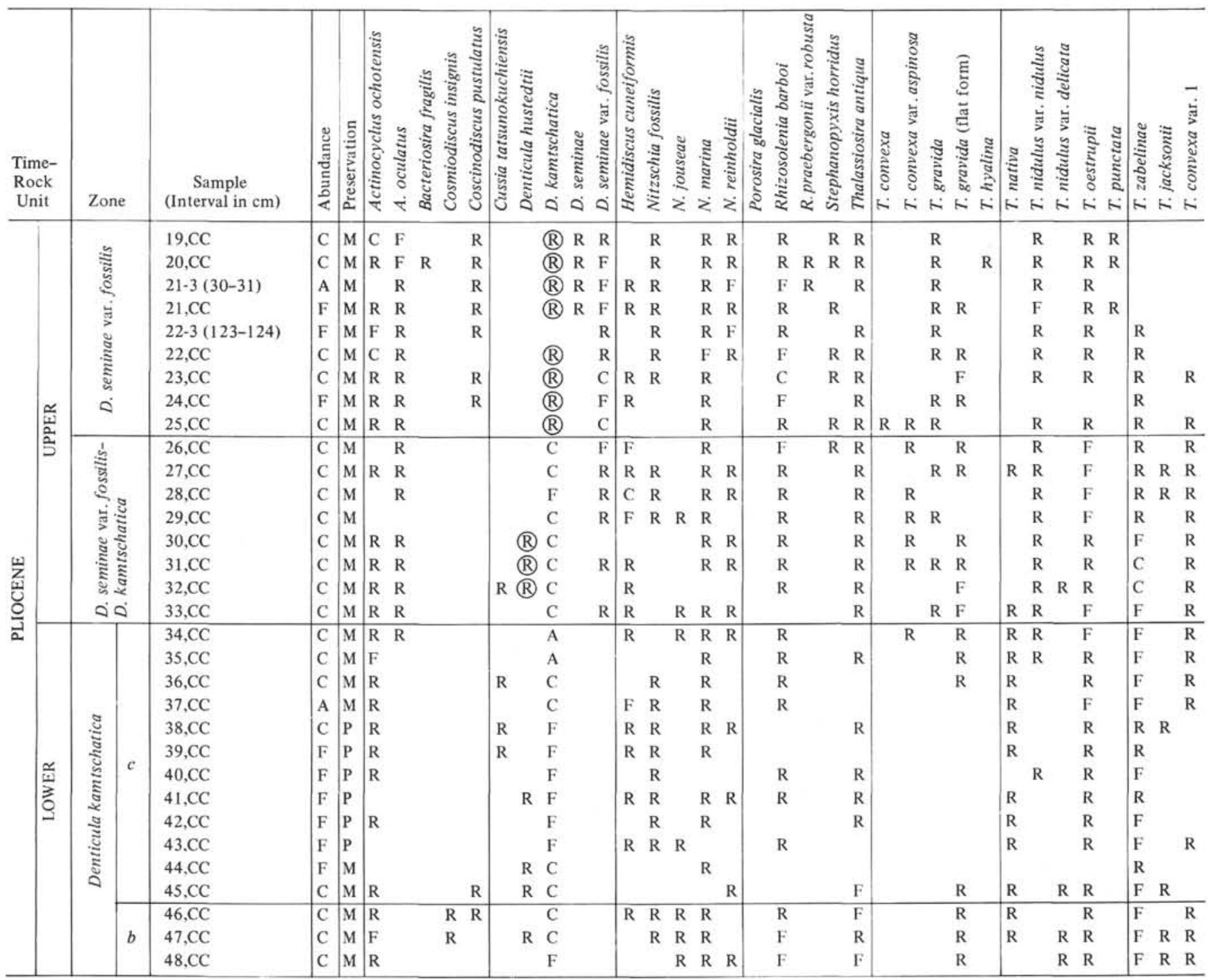

with the last occurrences of Stephanopyxis horridus and C. pustulatus in Sample 440B-18,CC (307.6 m). Very rare $T$. antiqua and $T$. punctata in Cores 15 through 17 may represent reworking, because nannofossils (Shaffer, this volume) and radiolarians (Reynolds, this volume) assign these cores to the Quaternary.

Pseudoeunotia doliolus has its first occurrence in the uppermost part of the Denticula seminae var. fossilis Zone in Sample 440B-18,CC (307.6 m). The D. seminae var. fossilis Zone occurs downhole through Core 25 and contains the first occurrence of $D$. seminae in Sample 440B-21, CC $(337 \mathrm{~m})$ and the last occurrences of $T$. $z a$ belinae (Sample 440B-22-3, 121-123 cm [341 m]) and $T$. convexa s. ampl. (Sample 440B-23,CC [355 m]), as reported by Koizumi (1977) for middle latitudes of the North Pacific.

The last common occurrence of $D$. kamtschatica in Sample 440B-26,CC (378.5 m) marks the top of the $D$. seminae var. fossilis-D. kamtschatica Zone. As in Hole $438, D$. seminae var. fossilis is rare below the top of this zone, and the last occurrence of $N$. jouseae is in the upper part of the zone (Sample 440B-29,CC [410 m]).

The base of the $D$. seminae var. fossilis-D. kamtschatica Zone is placed at the first occurrence of $D$. seminae var. fossilis in Sample 440B-33, CC (450 m) and coincides with the last occurrence of $T$. nativa. The first occurrence of A. oculatus is immediately below in Sample $440 \mathrm{~B}-34, \mathrm{CC}(458.2 \mathrm{~m})$.

Cores 34 through 45 of Hole $440 \mathrm{~B}$ are assigned to Subzone $c$ of the D. kamtschatica Zone, and the last occurrence of Cosmiodiscus insignis in Sample 440B-46, CC $(572 \mathrm{~m})$ marks the top of Subzone $b$. As at Site 438, the first occurrence of $N$. jouseae is immediately below the top of Subzone $b$ in Sample 440B-48,CC (594 m).

The last occurrence of Rouxia californica and the first occurrence of $T$. oestrupii in Sample 440B-56,CC 
TABLE 12

Stratigraphic Occurrence of Selected Diatoms and the Silicoflagellate Distephanus pseudofibula, Cores 440B-49-440B-71

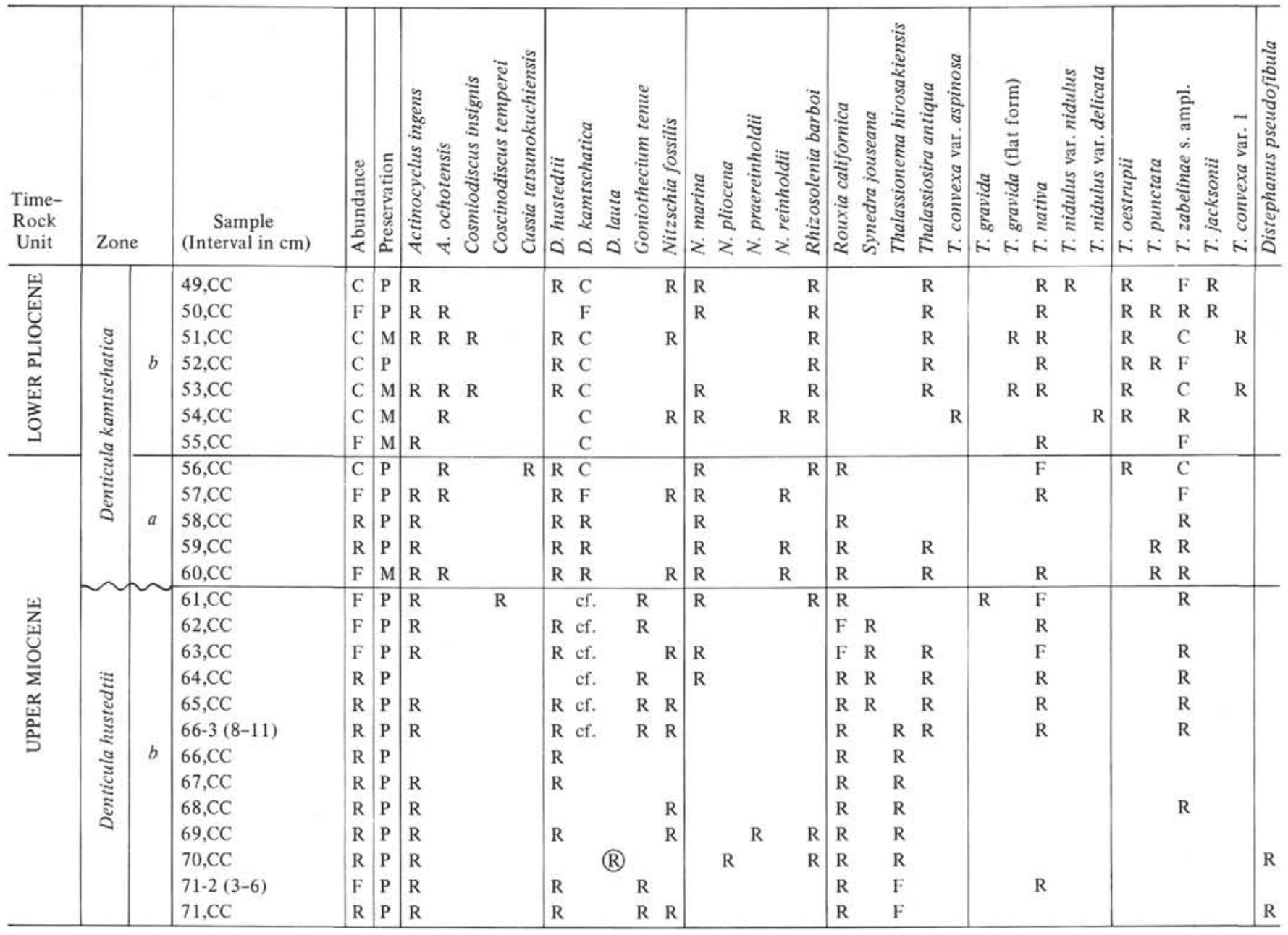

$(667 \mathrm{~m})$ define the base of Subzone $b$ and the top of Subzone $a$ of the D. kamtschatica Zone and approximate the Miocene/Pliocene boundary.

The base of the $D$. kamtschatica Zone is marked by the first occurrence of $D$. kamtschatica s. str. in Sample 440B-60,CC (705 m). The first occurrence of $N$. reinholdii is also at the base of the zone.

Assemblages in Cores 61 through 71 are correlated with Subzone $b$ of the D. hustedtii Zone. The last occurrence of Synedra jouseana in Sample 440B-62,CC (721 $\mathrm{m})$, the last occurrence of Thalassionema hirosakiensis in Sample 440B-66-3, 8-11 cm (761.5 m), the first occurrence of Thalassiosira zabelinae s. ampl. in Sample $440 \mathrm{~B}-68, \mathrm{CC}(780.6 \mathrm{~m})$, and the last occurrence of the silicoflagellate Distephanus pseudofibula in Sample $440 \mathrm{~B}-70, \mathrm{CC}(795 \mathrm{~m})$ suggest that this interval is correlative with Cores 43 through 45 of Hole $438 \mathrm{~A}$, so that the upper Miocene hiatus that was recognized in Core 42 of Hole 438A probably occurs between Cores 60 and 62 in Hole 440B (Figure 7).

\section{Site 441}

Site $441\left(39^{\circ} 45.05^{\prime} \mathrm{N}, 144^{\circ} 04.59^{\prime} \mathrm{E}\right.$; $5655 \mathrm{~m}$ water depth) was drilled on the lower continental slope with the objective of penetrating the accretionary prism. Unfortunately the results were rather disappointing. Core recovery was small, and a third attempt at sampling at this site had to be terminated when the drill string became stuck.

Upper Miocene through Quaternary sediment was recovered from the three holes $(441,441 \mathrm{~A}$, and 441B) drilled at Site 441 . The stratigraphic occurrences of selected diatoms in a composite of these three holes are shown in Table 13. At Site 441 a thin (about $3 \mathrm{~m}$ ) cover of upper Quaternary (Denticula seminae Zone) unconformably overlies a thicker section of Pliocene and upper Miocene sediment. Although recovery was small and discontinuous, no repetition of section was observed; a normal sequence from the $D$. seminae var. fossilis through the $D$. seminae var. fossilis- $D$. kamtschatica Zone and into the $D$. kamtschatica Zone is present (Table 13). Cores 10 and 11 of Hole 441A (577-587 m), however, contain very poorly preserved middle Miocene diatoms such as Coscinodiscus endoi, $C$. lewisianus, $D$. lauta, and Mediaria splendida without younger diatoms. It is possible that the highly brecciated sediment of these cores represents a slump of material that is exposed upslope. 


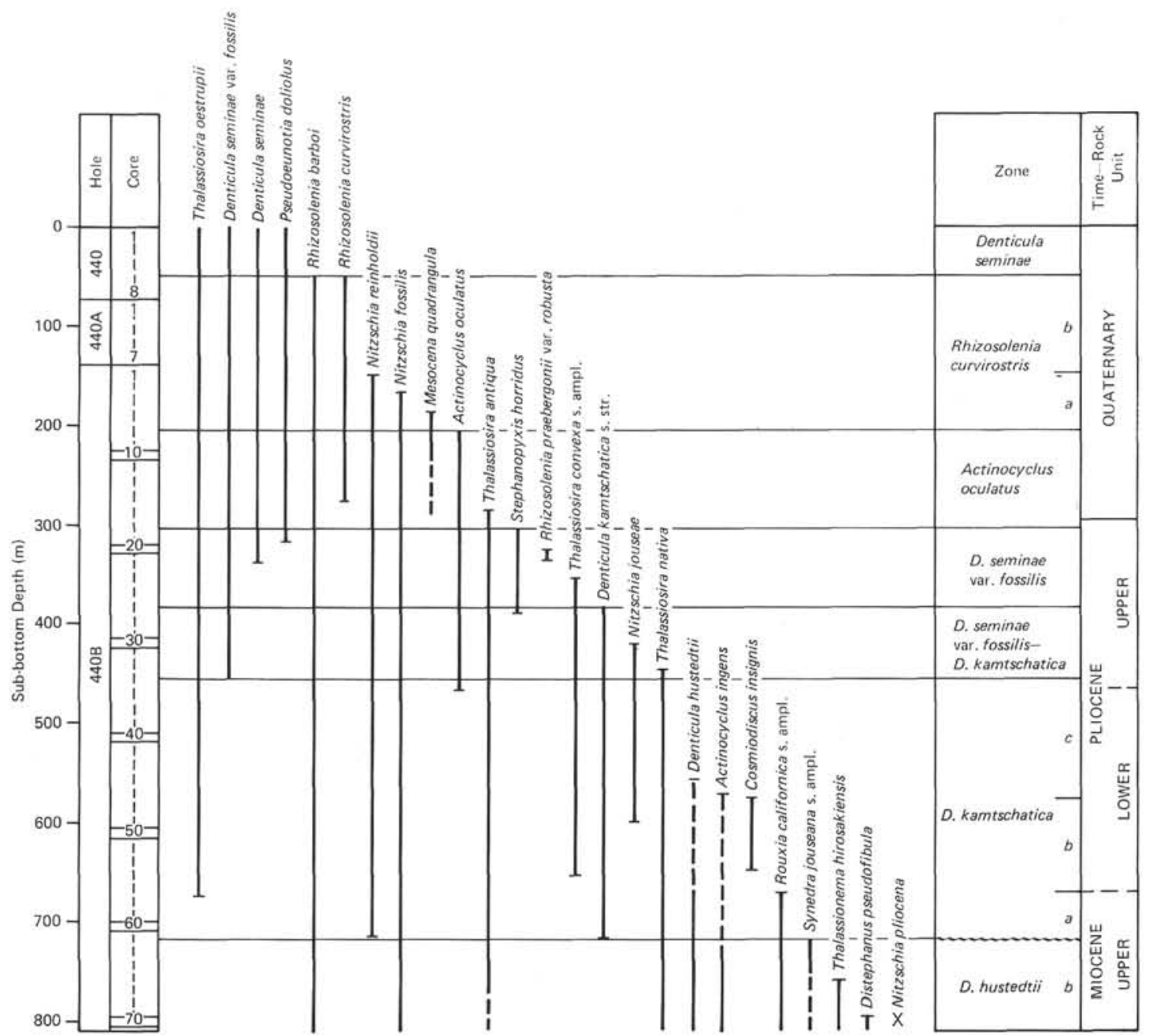

Figure 6. Stratigraphic ranges of selected diatoms and the silicoflagellates Mesocena quadrangula and Distephanus pseudofibula in the section cored at Site 440. (Note the near correspondence between the first occurrence of Denticula seminae var. fossilis and the last occurrence of Thalassiosira nativa.)

Preservation is good to moderate down to Sample $441-4, \mathrm{CC}(26.0 \mathrm{~m})$; generally moderate in the interval below through Sample 441-9, CC (267.2 m); moderate to poor from Sample 441B-1-2, 62-64 cm (337.6 m), through Sample 441A-8,CC $(511.6 \mathrm{~m})$; and poor below that level. Diatoms are common to abundant down to Core 9 of Hole 441 (264 m); few in the interval from Sample 441B$1-2,62-64 \mathrm{~cm}(337.6 \mathrm{~m})$, through Sample 441A-8,CC $(511.6 \mathrm{~m})$; and rare below that level.

Sample 441-2-1, 30-32 cm (7.3 m), lies just below the Pliocene-Quaternary boundary, as evidenced by the joint occurrences of Rhizosolenia praebergonii var. robusta, Pseudoeunotia doliolus, and Thalassiosira anti$q u a$. The base of the D. seminae var. fossilis Zone is approximated by the last common occurrence of $D$. kamtschatica in Sample 441-7-1, 65-67 cm (150.1 m). Nitzschia jouseae has its last occurrence in the same sample. Important datum levels within the $D$. seminae var. fossilis Zone include the first occurrence of $P$. doliolus in Sample 441-2-3, 90-92 cm (10.9 cm), and the apparent last occurrence of $T$. convexa var. aspinosa in Sample 441-3,CC (16.7 m).
The D. seminae var. fossilis-D. kamtschatica Zone occurs from Sample 441-7-1, 65-67 cm (150.1 m), through approximately Sample 441-9,CC (267.2 m), where $A c$ tinocyclus oculatus has its first occurrence. D. seminae var. fossilis is rare or absent within this interval, as it was at Sites 438 and 440.

The interval from Sample 441B-1-2, 62-64 cm (337.6 m) through Sample 441A-8,CC (511.6 m) is assigned to Subzone $c$ of the D. kamtschatica Zone. Cosmiodiscus insignis was not recorded in these fairly poorly preserved assemblages, and the base of the subzone is approximated by the first occurrence of $N$. jouseae.

The last occurrence of Rouxia californica in Sample 441A-11-1, 50-52 cm (568.5 m), marks the top of Subzone $a$ of the D. kamtschatica Zone and the Miocene/Pliocene boundary. The poorly preserved assemblages down through Sample 441B-2-2, 78-80 cm (670.3 m), near the base of the section sampled at Site 441 , are assigned to the upper Miocene Subzone $a$ of the D. kamtschatica Zone, based on the co-occurrences of D. kamtschatica s. str., $N$. reinholdii, and $R$. californica. Wash core Sample 441B-H-2-4, 130-150 cm (402.0-668.0 m), 


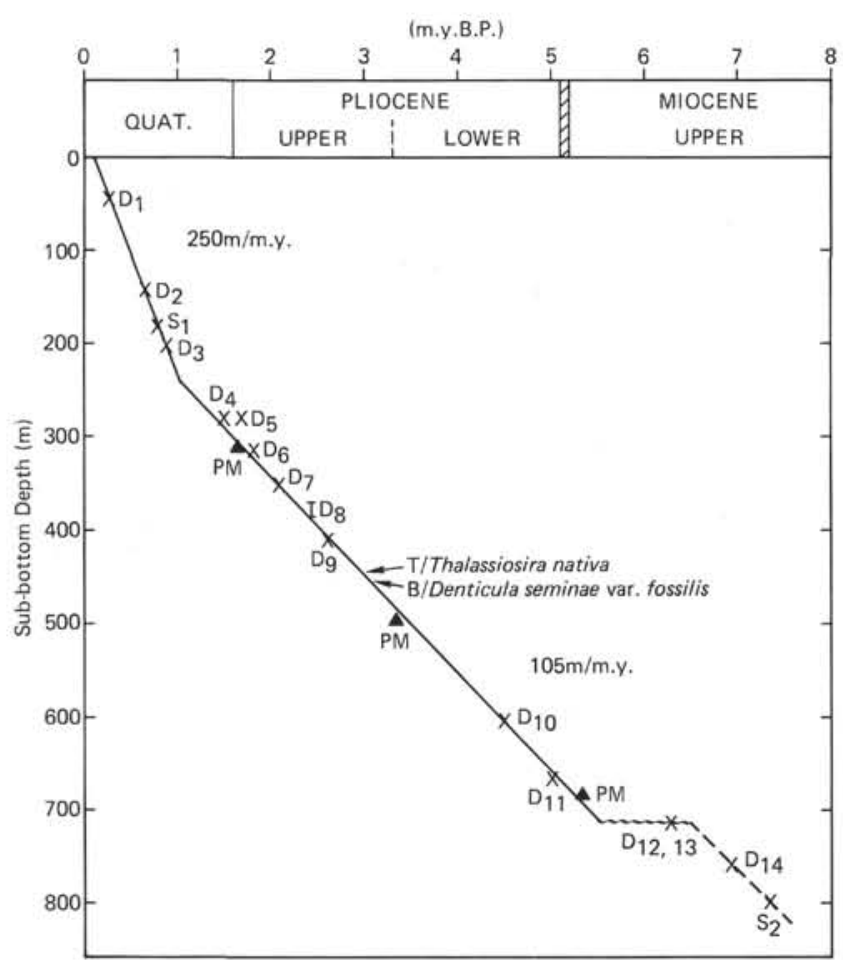

Figure 7. Sediment accumulation rate curve for Site 440 plotted from diatom and silicoflagellate datum levels listed below. (PM = Paleomagnetic boundaries determined in Hole 440B [Hall et al., this volume]: top of Olduvai Event $=310 \mathrm{~m}$; Gauss $/$ Gilbert $=495 \mathrm{~m}$; and Gilbert/Epoch $5=680 \mathrm{~m}$. Datum levels: $\mathrm{D}_{1}=$ last Rhizosolenia curvirostris, $\mathrm{D}_{2}=$ last Nitzschia reinholdii, $\mathrm{S}_{1}=$ last Mesocena quadrangula [silicoflagellate], $\mathrm{D}_{3}=$ last Actinocyclus oculatus, $\mathrm{D}_{4}=$ first $\mathrm{R}$. curvirostris, $\mathrm{D}_{5}=$ last Thalassiosira antiqua, $\mathrm{D}_{6}=$ first Pseudoeunotia doliolus, $\mathrm{D}_{7}=$ last $\mathrm{T}$. convexa, $\mathrm{D}_{8}=$ last Denticula kamtschatica, $\mathrm{D}_{9}=$ last $\mathrm{N}$. jouseae, $\mathrm{D}_{10}=$ first $\mathrm{N}$. jouseae, $\mathrm{D}_{11}=$ first $\mathrm{T}$. oestrupii, $\mathrm{D}_{12}=$ first $\mathrm{D}$. kamtschatica, $\mathrm{D}_{13}=$ first N. reinholdii. Other datum levels extrapolated from the sediment accumulation rate curve for Hole 438A: $\mathrm{D}_{14}=$ last Thalassionema hirosakiensis, $\mathrm{S}_{2}=$ last Distephanus pseudofibula [silicoflagellate]. See Table 14 for absolute ages of datum levels. The last Thalassiosira nativa, at about 145 meters, has an absolute age estimated at 2.95 m.y.B.P. by the curve. The first $\mathrm{D}$. seminae var. fossilis, at about 155 meters, has an absolute age estimated at about 3.1 m.y.B.P. by the curve.)

contains $N$. miocenica, $T$. miocenica, and D. kamtschatica s. str. and is very similar to the uppermost Miocene assemblage recovered from Hole 438A.

\section{DISCUSSION}

In Figure 8 the holes drilled during Leg 57 are correlated by diatoms and silicoflagellates. Thin Quaternary sections in Holes 438 and $438 \mathrm{~A}$ and at Site 441 are contrasted with a thick (about $300 \mathrm{~m}$ ) Quaternary section at Site 440 . The good biostratigraphic control suggests similar Pliocene and uppermost Miocene sections at Sites 438 and 440 . Poor recovery at Site 441 results in relatively few correlations with the other sites, but an expanded Pliocene section at Site 441 is indicated. Whether this thickened section is due to imbrication or greater sediment accumulation rates at Site 441 cannot be determined from the available diatom data.

Figure 8 also shows that the uppermost Miocene hiatuses in Core 42 of Hole 438A and between Cores 60 and 62 of Hole 440B are correlative.

Miocene stratigraphic levels in Holes 438B and 439 appear to be about 10 to 30 meters lower than they are in Hole 438A. Figure 8 reveals that the composite section drilled at Sites 438,439 , and 440 represents a nearly complete upper lower Miocene through Quaternary reference section for diatoms.

A number of diatom and silicoflagellate datum levels in the equatorial and North Pacific have been correlated to paleomagnetic stratigraphy by Burckle $(1972,1977$, 1978), Burckle and Opdyke (1977), Koizumi (1975d), and Donahue (1970) (Table 14). In addition, Koizumi (1977) provides estimates of the absolute age of the first occurrence of Denticula hustedtii and the last occurrence of $D$. lauta from potassium-argon dates in Japan.

In Figures 5 and 7 these datum levels and the results of paleomagnetic studies on Leg 57 sediments (Hall and others, this volume) are used to construct sediment accumulation rate curves for Hole 438A and Site 440. In both cases, all of the points corresponding to the datum levels lie on or very near the plotted curve and attest to the good biostratigraphic control available in both sections. Upper Miocene and middle Miocene datum levels, tied to paleomagnetic stratigraphy in the equatorial Pacific by Burckle (1978), appear to show little or no diachroneity at the $40^{\circ} \mathrm{N}$ latitude of Site 438 .

Figure 5 suggests sediment accumulation rates at Site 438 of about $30 \mathrm{~m} / \mathrm{m}$.y. for the Quaternary and uppermost Pliocene, about $108 \mathrm{~m} / \mathrm{m}$.y. for the remainder of the Pliocene and the uppermost Miocene, about $40 \mathrm{~m} / \mathrm{m}$.y. for the bulk of the upper Miocene and upper middle Miocene, and about $100 \mathrm{~m} / \mathrm{m} . \mathrm{y}$. for the lower middle Miocene and upper lower Miocene. The uppermost Miocene hiatus in Core 42 of Hole 438A and a middle Miocene hiatus between Cores 65 and 66 of Hole 438A are also revealed by the plot.

Control on the bottom portion of the curve in Figure 5 is poor. The single occurrence of Annellus californicus in Sample 438A-73,CC (754.5 m), however, appears to approximate its correlative last occurrence in the southern California Continental Borderland based on its position just below the first occurrence of $D$. hyalina in Sample 438A-73-5, 46-48 cm (751.5 m) (Barron, unpublished data). Studies in the southern California Continental Borderland also suggest that the first occurrence of D. lauta s. str. is close to the lower Miocene/ middle Miocene boundary, or about 15.5 m.y.B.P.

At Site 440, Figure 7 predicts sediment accumulation rates of about $250 \mathrm{~m} / \mathrm{m}$.y. for the upper and middle parts of the Quaternary and about $105 \mathrm{~m} / \mathrm{m}$.y. for the lower Quaternary through upper Miocene. The lower rate is very similar to the rate plotted for the Pliocene of Hole 
TABLE 13

Stratigraphic Occurrence of Selected Diatoms in Holes 441, 441A, and 441B

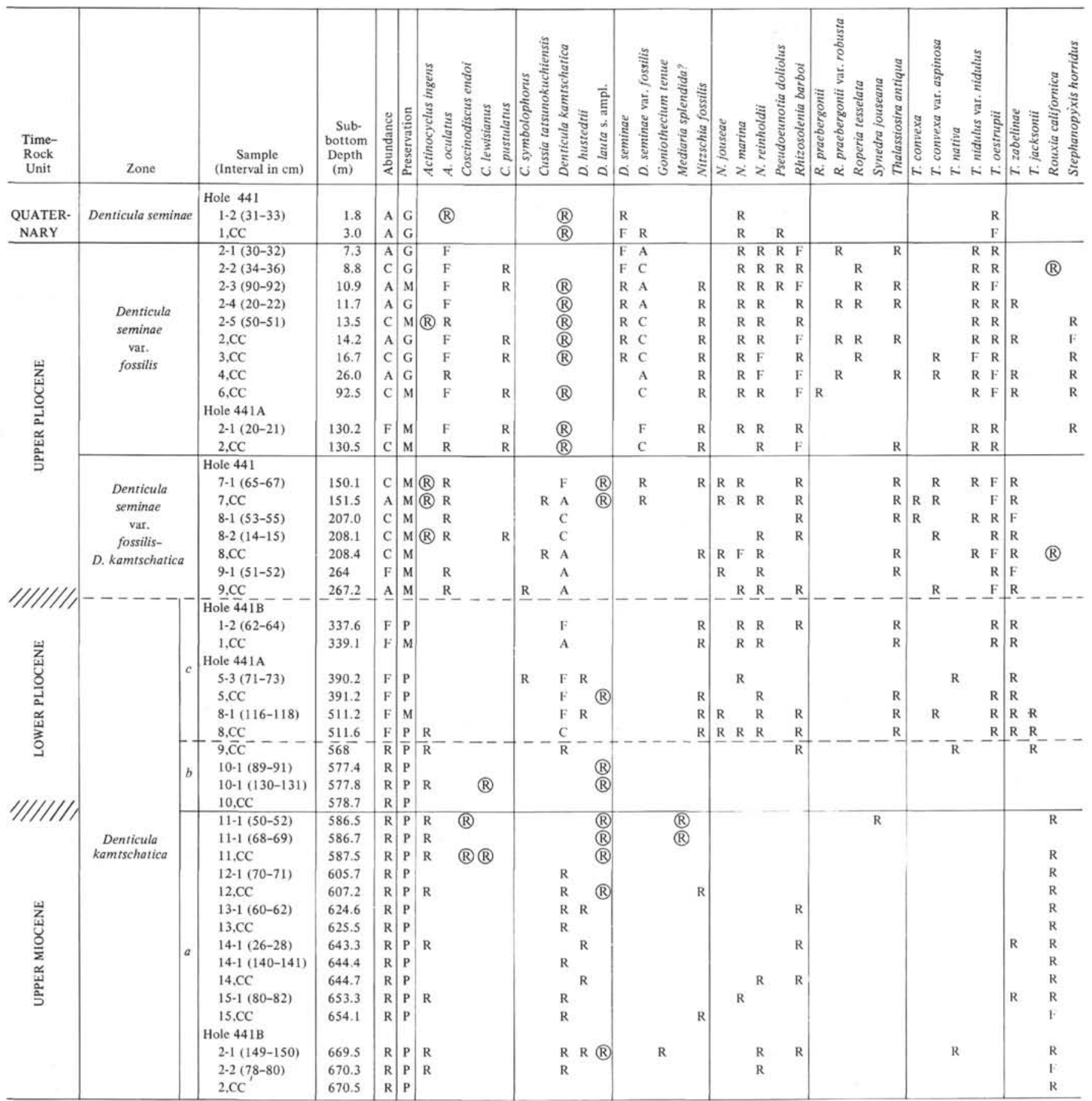

438A (about $108 \mathrm{~m} / \mathrm{m} . \mathrm{y}$.). An upper Miocene hiatus spanning the interval from about 6.5 to 5.5 m.y.B.P. is shown at about 710 meters, or between Cores 60 and 62 of Hole 440B. This hiatus corresponds closely in time and duration to an upper Miocene hiatus in Core 42 of Hole 438A (Figure 5).

The sediment accumulation rate curves (Figures 5 and 7) and the occurrence charts for Sites 438 and 440 provide the means of estimating the absolute ages of secondary diatom datum levels in the Leg 57 area. Fig- ure 9 shows the diatom zonation for Leg 57, with primary and secondary datum levels plotted against a paleomagnetic time scale derived from LaBrecque and others (1977) and MacDougall and others (1977). Symbols indicate whether an individual datum level is correlated directly to the paleomagnetic scale or is extrapolated from the sediment accumulation rate curves. These secondary datum levels provide additional control and permit easy correlation with diatom zonations in use in other parts of the North Pacific. 


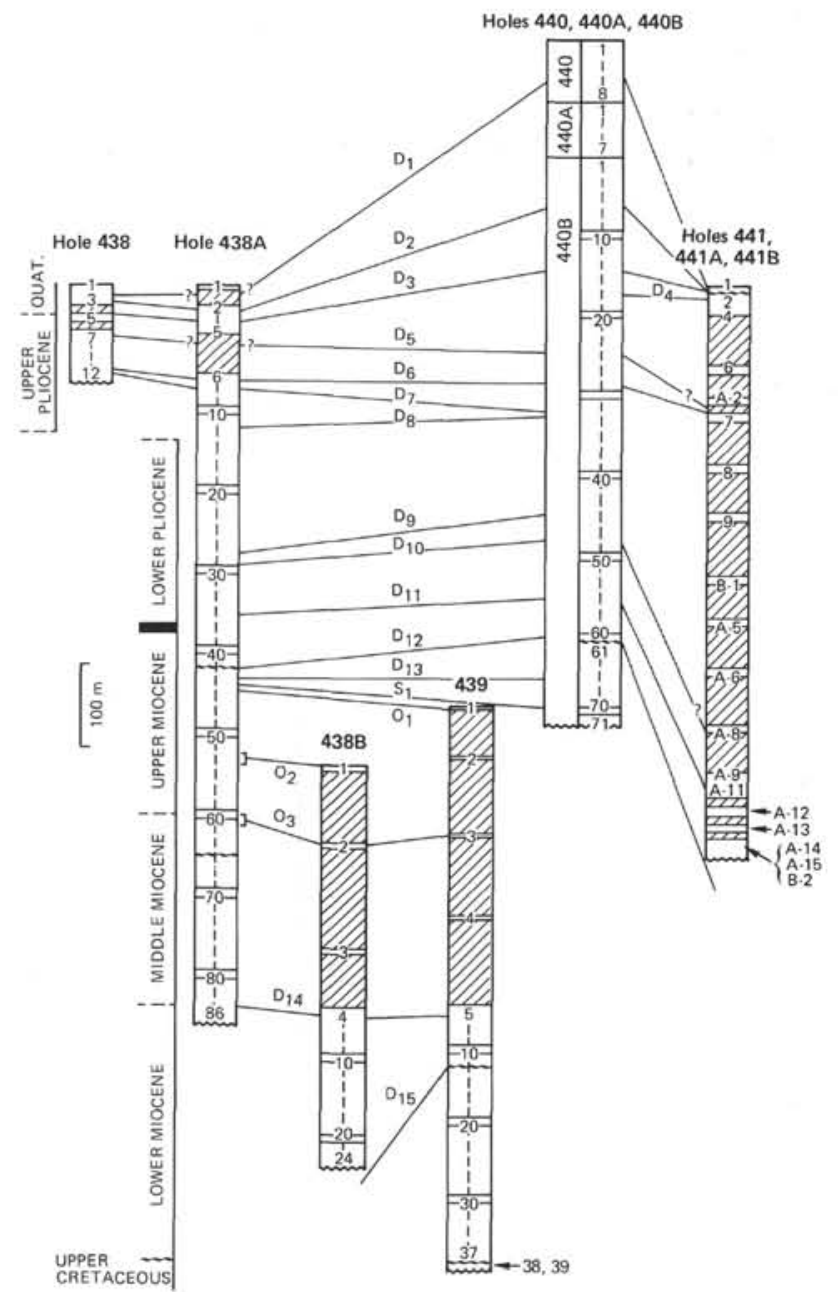

Figure 8. Correlation of Leg 57 holes as determined by diatom and silicoflagellate datum levels. $\left(\mathrm{D}_{1}=\right.$ last Rhizosolenia curvirostris, $\mathrm{D}_{2}=$ last Actinocyclus oculatus, $\mathrm{D}_{3}=$ last Thalassiosira antiqua, $\mathrm{D}_{4}=$ first Pseudoeunotia doliolus, $\mathrm{D}_{5}=$ last Denticula kamtschatica, $\mathrm{D}_{6}=$ last Nitzschia jouseae, $\mathrm{D}_{7}=$ last Cussia tatsunokuchiensis, $\mathrm{D}_{8}=$ last Thalassiosira nativa, $\mathrm{D}_{9}=$ last Cosmiodiscus insignis, $\mathrm{D}_{10}=$ first $\mathrm{N}$. jouseae, $\mathrm{D}_{11}=$ last Rouxia californica, $\mathrm{D}_{12}=$ first D. kamtschatica and first $\mathrm{N}$. reinholdii, $\mathrm{D}_{13}=$ last Thalassionema hirosakiensis, $\mathrm{S}_{1}=$ last Distephanus pseudofibula [silicoflagellate], $\mathrm{O}_{1}=$ overlap of $\mathrm{D}$. pseudofibula [silicoflagellate] and Thalassiosira antiqua, $\mathrm{O}_{2}=$ occurrence of Coscinodiscus endoi above the last Denticula lauta, $\mathrm{O}_{3}=$ overlap of Distephanus pseudofibula and Mesocena hexagona [silicoflagellates], $\mathrm{D}_{14}=$ first Denticula lauta, $\mathrm{D}_{5}=$ first Coscinodiscus endoi and first Coscinodiscus lewisianus. Cross-hatched areas represent intervals not recovered.)

In Figure 10 the middle Miocene and upper Miocene of Hole $438 \mathrm{~A}$ are correlated by diatoms with the section cored at DSDP Site 173 (Figure 1) off northern California. Several datum levels result in a detailed correlation. The last occurrence of Coscinodiscus yabei, however, is diachronous; it occurs in the upper Miocene at Site 438
TABLE 14

Correlation of Diatom and Silicoflagellate Datum Levels to Paleomagnetic Stratigraphy and Estimate of Absolute Age

\begin{tabular}{|c|c|c|c|}
\hline & Datum & Paleomagnetic Tie & $\begin{array}{l}\text { Estimated Age } \\
\text { (m.y.B.P.) }\end{array}$ \\
\hline $\mathrm{T}$ & Rhizosolenia curvirostris & upper Brunhes $(5,6,8)$ & 0.26 \\
\hline $\mathrm{T}$ & Nitzschia reinholdii & lower Brunhes $(5,6,7)$ & 0.63 \\
\hline $\mathbf{T}$ & $\begin{array}{l}\text { Mesocena quadrangula } \\
\quad \text { (silicoflagellate) }\end{array}$ & between Jaramillo and Brunhes ( 7$)$ & 0.79 \\
\hline $\mathrm{T}$ & Actinocyclus oculatus & in Jaramillo $(5,8)$ & 0.9 \\
\hline B & R. curvirostris & between Olduvai and Jaramillo $(3,6)$ & 1.5 \\
\hline $\mathrm{T}$ & $\begin{array}{l}R \text {. praebergonii } \\
\text { var. robusta }\end{array}$ & just above top of Olduvai (7) & 1.55 \\
\hline B & Thalassiosira antiqua & middle Olduvai (5) & 1.7 \\
\hline B & Pseudocunotia doliolus & lower Olduvai $(3,5,6,7)$ & 1.8 \\
\hline $\mathrm{T}$ & T. convexa & $\begin{array}{l}\text { midway between Olduvai and top of } \\
\text { Gauss }(6,7)\end{array}$ & 2.1 \\
\hline $\mathrm{T}$ & Denticula kamtschatica & top of Gauss (6) & 2.4 \\
\hline $\mathrm{T}$ & N. jouseae & near top of Gauss $(1,5)$ & 2.6 \\
\hline B & D. seminae var. fossilis & $\begin{array}{l}\text { between " } b \text { " and " } c \text { " events of the } \\
\text { Gilbert (5) }\end{array}$ & 4.2 \\
\hline B & N. jouseae & between "c" events of Gilbert (4) & 4.5 \\
\hline B & T. oestrupii & lowermost Gilbert (5) & 5.0 \\
\hline & T. miocenica & $\begin{array}{l}\text { midway between "c" event of Gilbert } \\
\text { and top of Epoch } 5(1)\end{array}$ & 5.0 \\
\hline $\mathbf{T}$ & Asterolampra acutiloba & top of Epoch 5 (1) & 5.3 \\
\hline & N. miocenica & top of "a" event, Epoch $5(1,3)$ & 5.4 \\
\hline B & T. convexa & upper Epoch $6(1,3)$ & 6.0 \\
\hline B & T. miocenica & upper Epoch 6 (1) & 6.0 \\
\hline B & D. kamtschatica & lower Epoch 6 (4) & 6.4 \\
\hline B & N. reinholdii & lower Epoch 6 (1) & 6.4 \\
\hline $\mathrm{T}$ & N. porteri & middle Epoch $7(1,3)$ & 6.9 \\
\hline B & N. miocenica & middle Epoch $7(1,3)$ & 7.0 \\
\hline & T. burckliana & lower Epoch $7(1,3)$ & 7.5 \\
\hline & Coscinodiscus yabei & middle Epoch $8(1,3)$ & 8.0 \\
\hline B & T. burckliana & upper Epoch 9 (1) & 8.5 \\
\hline $\mathrm{T}$ & D. lauta & $\mathrm{K}-\mathrm{Ar}$ date (2) & 9.5 \\
\hline B & Hemidiscus cuneiformis & middle Epoch 12 (1) & 11.9 \\
\hline $\mathrm{T}$ & C. lewisianus & upper Epoch 13 (1) & 12.3 \\
\hline $\mathrm{T}$ & D. nicobarica & upper Epoch 14 (1) & 12.5 \\
\hline B & D. hustedtii & K-Ar date (2) & 14.0 \\
\hline$T$ & Annellus californicus & lower Epoch 15 (1) & 14.5 \\
\hline B & A. californicus & upper Epoch $16(1)$ & 15.5 \\
\hline
\end{tabular}

and in the middle Miocene at Site 173. This relationship probably reflects warmer paleotemperatures at Site 438 than at Site 173 during the early late Miocene.

The uppermost Miocene hiatus in Core 42 of Hole 438A correlates with a hiatus of similar duration in Core 15 of Site 173. The middle Miocene hiatus between Cores 65 and 66 of Hole 438A apparently removes the interval equivalent to about Cores 23 through 25 of Site 173. Figure 10 also suggests that the single occurrence of Annellus californicus in Sample 438A-73,CC correlates with its last occurrence at Site 173.

\section{Diatom Zonal Correlations}

In Figure 11 the modified diatom zonation of Koizumi $(1973,1975 b)$ that was used for Leg 57 is correlated with the low-latitude diatom zonation of Burckle $(1972,1977)$, the North Pacific diatom zonation of the California area of Schrader (1973) and Barron (1976), and the diatom zonation used onshore in Japan by Akiba (1979; written communication, 1977). The occurrence charts for Sites 438 and 440 and Figures 9 and 10 provide background for these correlations.

Most of the subzones proposed for Koizumi's (1973, 1975 b) diatom zonation were chosen so that their boundaries correspond with zonal boundaries of the other zonations. It is suggested that many of these subzones will 


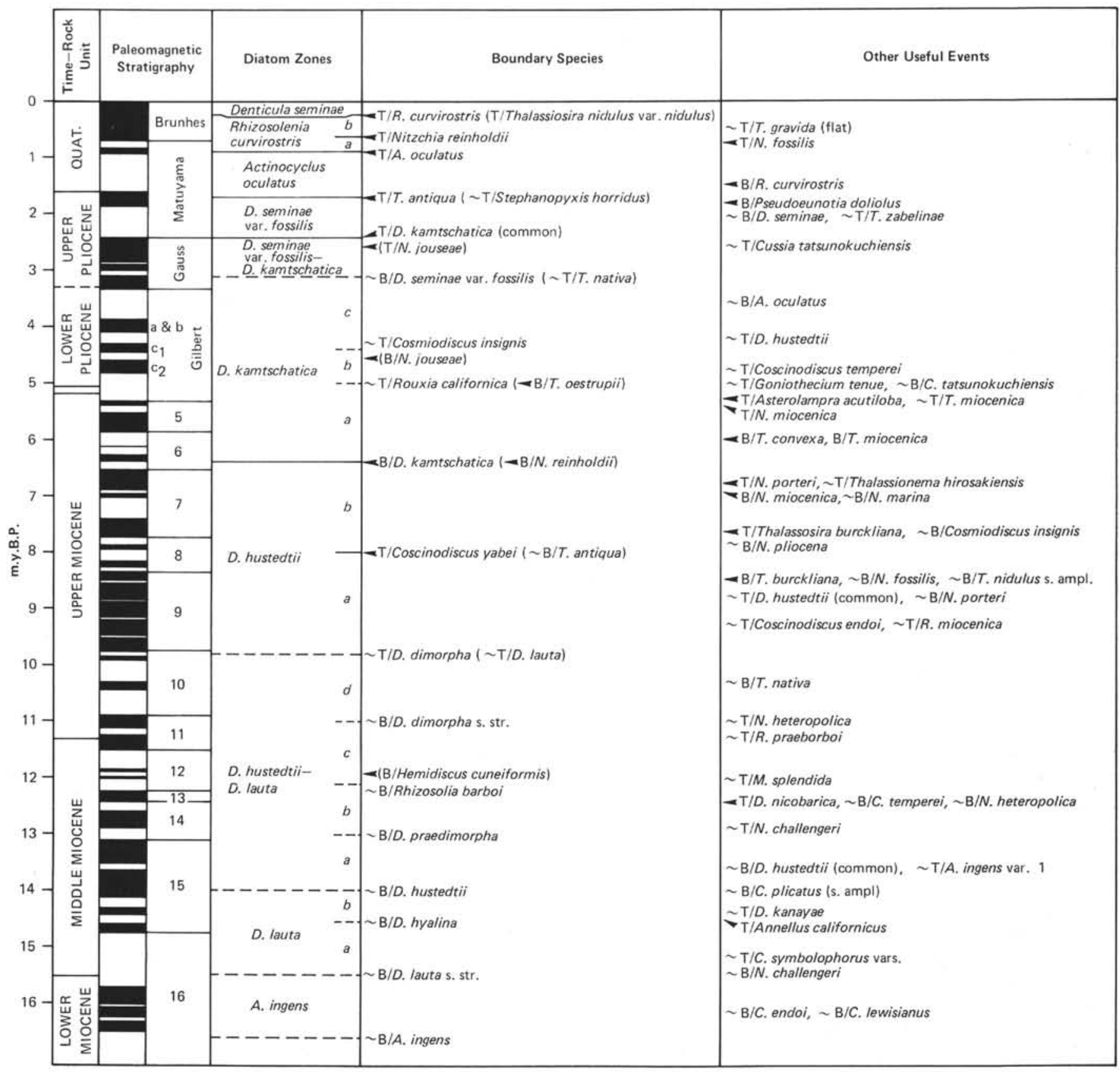

Figure 9. Estimated absolute ages for the Leg 57 diatom zones and selected datum levels. (The paleomagnetic time scale is that of MacDougall and others [1977] for the Gilbert Paleomagnetic Epoch and Epochs 5 and 6 and LaBrecque and others [1977] for the remainder of the period covered. Datum levels established directly from paleomagnetically dated cores are indicated by arrows [-]. Other datum levels are extrapolated from sediment accumulation rate curves and are indicated by a wavy line.)

have broad application throughout the North Pacific. On Leg 63, the subzones of the Denticula hustedtii Zone, the $D$. hustedtii- $D$. lauta Zone, and the $D$. lauta Zone were consistently recognized in sediments off southern California and Baja California, Mexico (Barron, unpublished data).

\section{Uppermost Miocene Hiatus}

The uppermost Miocene hiatus that was recognized in Core 42 of Hole 438A and between Cores 60 and 62 of Hole 440B appears to be widespread in the mid- to high-latitude North Pacific. It is present in the lower part of Core $15(135 \mathrm{~m})$ at DSDP Site 173 off northern California (Figure 1), where it is of approximately the same duration (about 1 m.y.) as it is at Site 438 (Figure 10). Onshore in California, it seems to correspond with the lithologic break between the laminated diatomaceous shales of the Monterey Formation and the overlying more terrigenous, massive diatomaceous mudstones represented by the Capistrano, the Sisquoc, the Pancho 


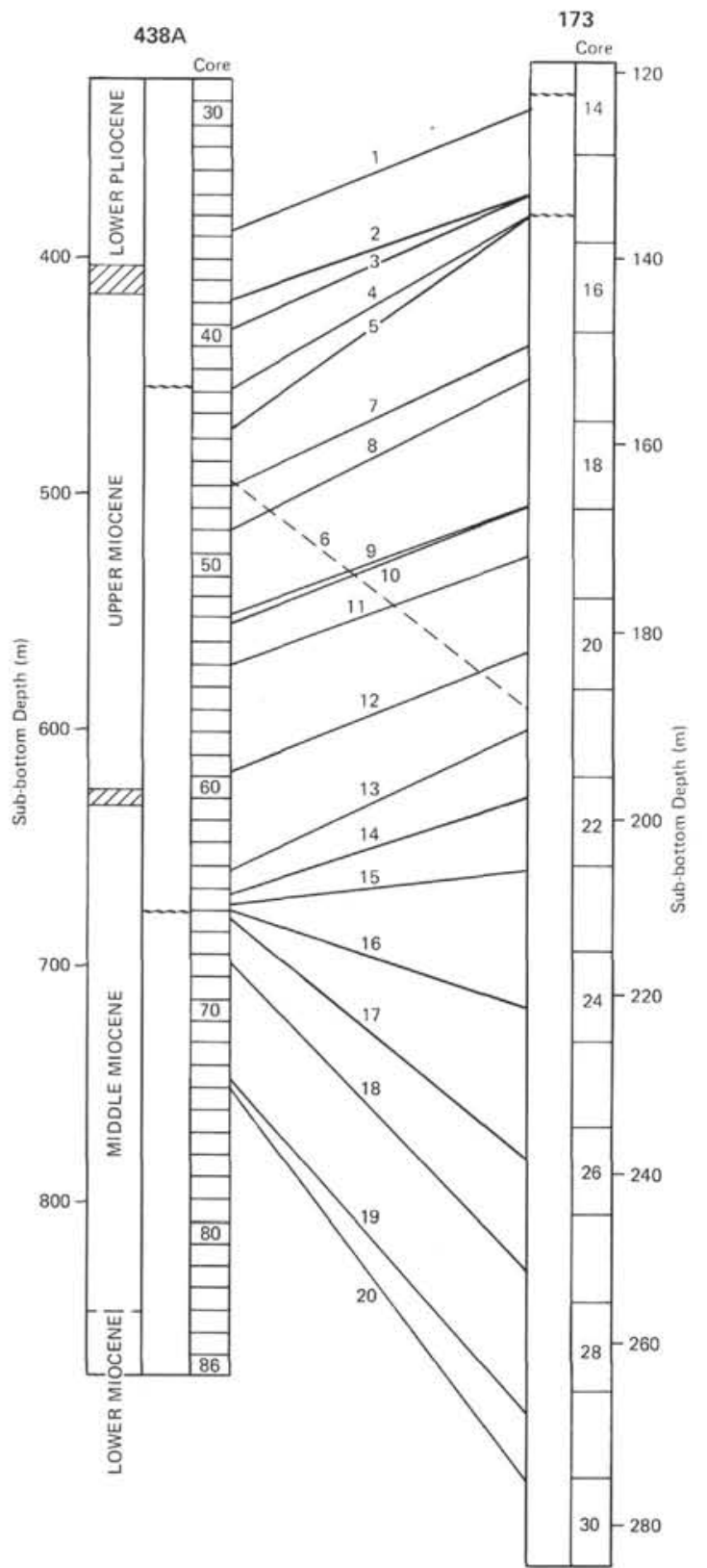

Figure 10. Correlation of the upper and middle Miocene in Hole 438A with the upper and middle Miocene at Site 173 off northern California by diatom datums. $(1=$ first Thalassiosira eostrupii, $2=$ last $\mathrm{T}$. miocenica, $3=$ last Nitzschia miocenica, $4=$ first $\mathrm{N}$. reinholdii, $5=$ last $\mathrm{T}$. burckliana, $6=$ last Coscinodiscus yabei, $7=$ first $\mathrm{T}$. antiqua, $8=$ first $\mathrm{N}$. fossilis, $9=$ last $\mathrm{C}$. endoi, $10=$ last Rhizosolenia miocenica, 11 = last Denticula dimorpha, $12=$ first D. dimorpha, $13=$ first $\mathrm{R}$. barboi, $14=$ first $\mathrm{C}$. temperei, $15=$ last $\mathrm{D}$. nicobarica, $16=$ first $\mathrm{D}$. praedimorpha, $17=$ first common $\mathrm{D}$. hustedtii, 18 $=$ first $\mathrm{D}$. hustedtii, $19=$ first $\mathrm{D}$. hyalina, $20=$ last Annellus californicus. Note the correlation of the hiatus in Core 42 of Hole $438 \mathrm{~A}$ with a hiatus in Core 15 of Site 173. Note also the time-transgressive nature of the last occurrence of C. yabei [6] between Japan and California.)
Rico, and the Purisima formations. On Leg 63, uppermost Miocene hiatuses were identified at Site 469 off southern California and at Site 470 , which was drilled near Guadalupe Island off northern Mexico, very near the site of the Experimental Mohole Drilling (Figure 1) (Barron, unpublished data).

In the western North Pacific, Koizumi (in press) reports a hiatus between uppermost Miocene and middle Miocene sediments in the lower part of Core $6(52 \mathrm{~m})$ of DSDP Site 433 in the Emperor Seamount Chain, and Harper (this volume) records a possible break between uppermost Miocene and lower upper Miocene sediments between Cores 29 and 30 (about $280 \mathrm{~m}$ ) at Site 436, just east of the Japan Trench (Figure 1). These relations support the presence of a widespread sedimentologic event in the North Pacific which may be related to the Messinian Event of the Mediterranean Sea.

At Site 183 in the Gulf of Alaska, an assemblage including Denticula kamtschatica s. str., Thalassiosira miocenica, $T$. convexa var. aspinosa, and $T$. jacksonii is present in Sample 183-17-5, 100-101 cm (171 m). Immediately below in Sample 183-18-1, 130-131 cm (174.3 m), T. hirosakiensis occurs with Nitzschia pliocena and Synedra jouseana and without the younger diatoms present in Core 17. The younger assemblage is no older than 6 m.y.B.P. (Table 14), whereas occurrences in Hole 438A suggest that the older assemblage is not younger than 7 m.y.B.P. Gravel-sized pebbles in the upper $20 \mathrm{~cm}$ of Core 18 are further evidence of an uppermost Miocene hiatus at this horizon at Site 183.

Site 192 in the extreme northwest Pacific was discontinuously cored; however, Koizumi's (1973) and Harper's (1977a) data together suggest that the sediment accumulation rate increases significantly upsection between Core $23(569-578 \mathrm{~m})$ and Core $22(522-531 \mathrm{~m})$, corresponding with the first occurrence of $D$. kamtschatica s. str. in Core 22. Harper (1977a) records the last occurrence of S. jouseana, and Koizumi (1973) reports N. pliocena in Core 23 at Site 192, so it is possible that a hiatus is present between Cores 22 and 23 in the upper upper Miocene of Site 192.

These DSDP sites include three located on the continental slope (173, 438, and 440), two in the Emperor Seamount Chain (192 and 433), and four on the ocean floor $(183,436,469$, and 470). They range in depth from 1558 meters (Hole 438A) to 5240 meters (Site 436). During the latest Miocene, Sites 183 and 436 were located well away from land in the ocean basins. Subsequent movement of the Pacific Plate has brought them near the Aleutian and Japan Trenches, respectively. The widespread geographic distribution and varied tectonic settings of these sites argue against local tectonic events as the primary causes of these latest Miocene hiatuses.

Kennett (1977) presents evidence for global cooling in the latest Miocene, including a latest Miocene to earliest Pliocene development of the Antarctic ice sheet thicker than present; conspicuous global sea level regression, including isolation of the Mediterranean Basin ("the Messinian Event'); and increases in ice rafting and siliceous biogenic sedimentation rates in the Antarctic Southern Ocean. Planktonic foraminiferal faunas record a latest 


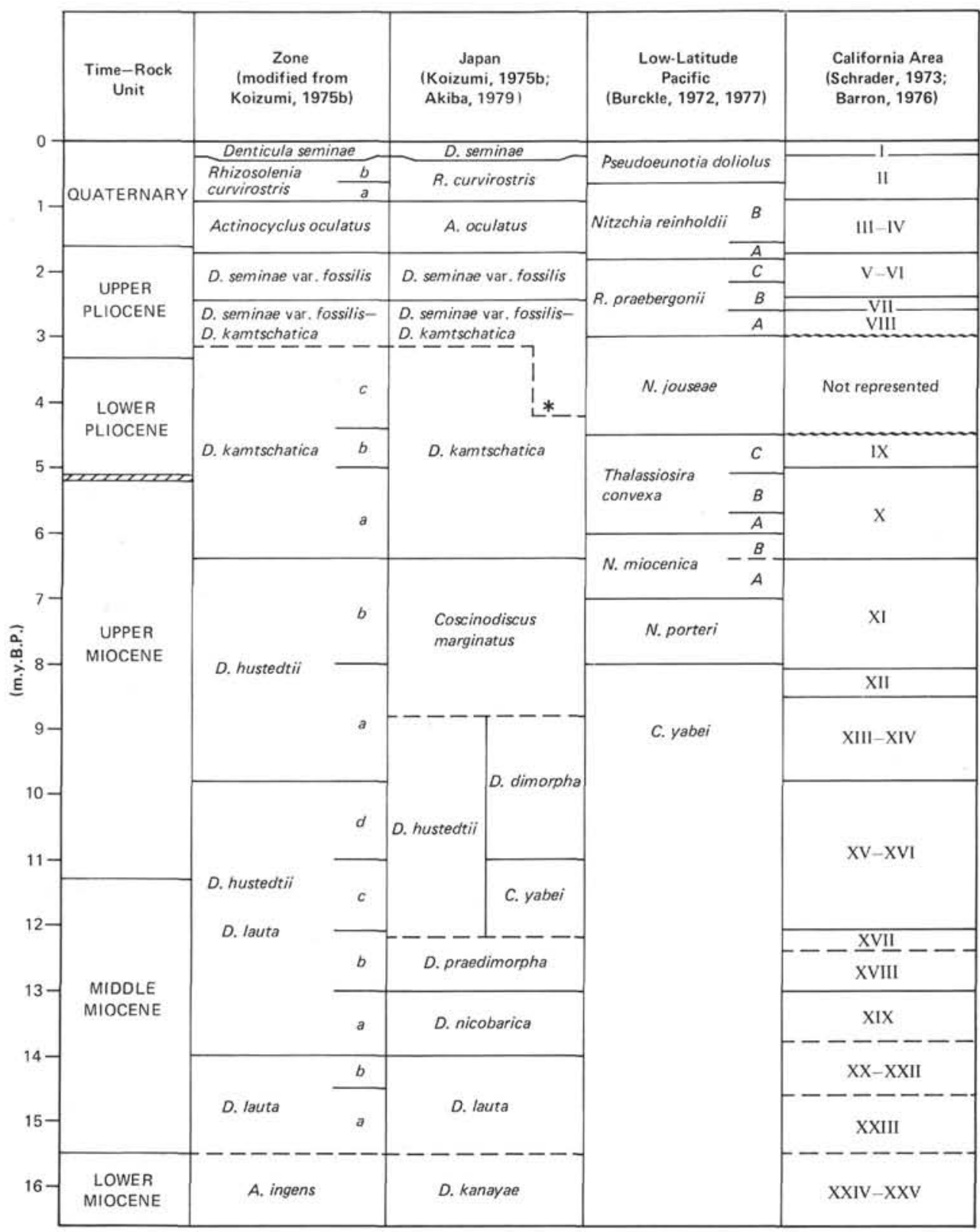

Figure 11. Correlation of the Leg 57 diatom zones modified from Koizumi (1973, 1975 b) with the low-latitude diatom zonation of Burckle (1972, 1977), the North Pacific Diatom Zonation of the California area of Schrader $(1973,1977)$, and with the diatom zonation used onshore in Japan by Akiba (in press, written communication, 1977). (*indicates that the base of the Denticula seminae var. fossilis-D. kamtschatica Zone appears to be somewhat older in more northern areas of the North Pacific [Burckle and Opdyke, 1977].)

Miocene cooling in the South Pacific and in New Zealand (Kennett, 1978), in Morocco (Cita and Ryan, 1978), and in the North Pacific (Ingle, 1978). In the Gulf of Alaska area, Armentrout and others (1978) report uppermost Miocene glacial marine sediments in the Yakataga Formation. Increased production of Antarctic ice results in increased activity of Antarctic bottom water (Gordon, 1971); and Kennett (1977) relates increased Antarctic bottom water production, which is associated with climatic deterioration near the beginning of the Oligocene, with extensive deep sea erosion throughout the ocean basins. Ciesielski and others (1978) report major erosion during the late late Miocene (from about 7.4 to 6.2 m.y.B.P.) on the Maurice Ewing Bank in the southwest Atlantic and relate it to an increase in velocity of the Antarctic Circumpolar Current. It is possible that the widespread latest Miocene hiatuses in the North $\mathrm{Pa}$ cific are the result of erosion owing to increased bottom water activity associated with a climatic cooling in the latest Miocene. The correspondence of the first occurrences of such high-latitude diatom species as $T$. gravida (two forms), $T$. jacksonii, $T$. zabelinae s. ampl., and $T$. 
nidulus var. delicata with the hiatus in Core 42 of Hole $438 \mathrm{~A}$ is support for this latest Miocene cooling at Site 438.

\section{Observations on Paleoclimatology}

Biostratigraphy is the primary aim of this study, and the assemblages are treated by qualitative rather than quantitative methods. Nevertheless, some observations on the response of the diatom assemblages to late Cenozoic climatic trends and events are offered.

\section{Quaternary}

In equatorial Pacific cores Burckle (1977) notes a shift in dominance from tropical diatoms to cosmopolitan forms at about 0.8 m.y.B.P., corresponding with the last occurrence of the silicoflagellate Mesocena elliptica (M. quadrangula). Burckle (1977) points out that this change is correlative with the onset of Isotopic Stage 22, which Shackleton and Opdyke (1976) call the first major Northern Hemisphere glaciation in the midPleistocene. In the western North Pacific, Koizumi (1975d) also identifies a general decrease in diatom temperature values (Td) during the same interval of time.

At Site 440 certain cold-water diatoms, including Bacteriosira fragilis, Porosira glacialis, Rhizosolenia hebetata f. hiemalis, Thalassiosira hyalina, and $T$. pacif$i c a$, are restricted to or occur more consistently above the middle part of Subzone $a$ of the Rhizosolenia curvirostris Zone (about 0.8 m.y.B.P.). In addition, the cold-water diatom Thalassiosira gravida increases in abundance upsection during this interval at Sites 438 and 440 . These occurrences and trends suggest that the late Quaternary (younger than about 0.8 m.y.B.P.) off northwestern Japan was, in general, cooler than the early Quaternary.

\section{Pliocene}

Oxygen isotope and paleomagnetic analysis by Shackleton and Opdyke (1977) on a piston core in the equatorial Pacific shows that " glacial-interglacial fluctuations have characterized the Earth's climate for the last 3.2 m.y." and that the intensity of glaciation increased at about 2.5 m.y.B.P. In the middle latitudes of the North Pacific, planktonic foraminifers also record cold periods at about 3.2 m.y.B.P. and 2.4 m.y.B.P. (Keller, 1978).

At Sites 438 and 440 , the first common occurrence of the cold-water diatom Denticula seminae var. fossilis is at about 2.5 m.y.B.P. and follows the last occurrence of the warm-water diatoms Nitzschia jouseae and Cussia tatsunokuchiensis. The last common occurrence of $D$. kamtschatica is also closely associated with the first common occurrence of $D$. seminae var. fossilis at Sites 438 and 440 and in many areas of the high-latitude North Pacific (Koizumi, 1973). These diatom events apparently are related to a widespread cooling at about 2.5 m.y.B.P.

The first occurrence of $D$. seminae var. fossilis in Leg 57 sediments off northeastern Japan is at about 3.1 m.y.B.P., much later than the datum reported by Burckle and Opdyke (1977) - about 4.2 m.y.B.P. - in a more central area of the North Pacific $\left(42^{\circ} 05^{\prime} \mathrm{N}, 160^{\circ}\right.$ $\left.36^{\prime} \mathrm{E}\right)$. Presumably, influence of the warm-water Kuroshio Current delayed the appearance of this cold-water diatom in Leg 57 sediments until after the initiation of global cooling at about 3.2 m.y.B.P.

\section{Late Miocene}

In the South Pacific, Kennett (1978) reports a severe cooling episode in the early late Miocene, followed by a middle late Miocene warming, and then a latest Miocene cooling. Ingle (1973) and Barron (1973) also give evidence of an early late Miocene cooling and a warming trend in the middle late Miocene in the eastern North Pacific. A latest Miocene to early Pliocene cooling is recorded by Keller (1978) in middle latitudes across the North Pacific.

At Site 438 lower upper Miocene diatom assemblages are dominated by species of the cold-water genus Denticula (D. hustedtii, D. lauta, and D. dimorpha). Specimens of Denticula are sparse in the middle upper Miocene (the upper part of the D. hustedtii Zone) but increase in numbers in the upper upper Miocene (lower part of the D. kamtschatica Zone). In the middle upper Miocene the first occurrences of such low-latitude diatoms as Nitzschia porteri, N. fossilis, and Thalassiosira burckliana are just above the last common occurrence of $D$. hustedtii. Consistent presence of key tropical diatoms in the middle upper Miocene of Site 438 allows recognition of all of the low-latitude diatom zones and subzones of Burckle (1972).

At Site 438 and 440 an uppermost Miocene hiatus corresponds with the base of the D. kamtschatica Zone. Correlative hiatuses throughout the middle- and highlatitude North Pacific suggest the possibility of widespread erosion during the late late Miocene owing to intensification of bottom water activity associated with climatic cooling. The first occurrences of such cold-water diatoms as $T$. gravida (two forms), $T$. jacksonii, $T$. nidulus var. delicata, and $T$. zabelinae s. str. coincide with the hiatus at Site 438 and Site 440 and support a cooling episode in the late late Miocene.

\section{Future Studies}

Studies of the middle Miocene to Quaternary paleoclimatology of the North Pacific will benefit from the refined interregional correlations that are now possible with diatoms. Quantitative comparisons of "time slices" should identify fossil diatom complexes that are associated with different paleoceanographic regions of the North Pacific. The Leg 57 sites, near the present-day confluence of the warm-water Kuroshio Current and cold-water Oyashio Current, offer a record that is characterized by fluctuations in abundance of numerous diatom taxa. These sites undoubtedly will be of great value in reconstructing the late Cenozoic climatic history of the entire North Pacific.

\section{ACKNOWLEDGMENTS}

I wish to thank Fumio Akiba, Itaru Koizumi, and Howard Harper for valuable discussion. Fumio Akiba was especially helpful and provided microscope slides of material from Ja- 
pan. Dave Bukry, U. S. Geological Survey, La Jolla, California, and Lloyd Burckle, Lamont-Doherty Geological Observatory, Palisades, New York, reviewed the manuscript and offered helpful suggestions. I wish also to thank Roland von Huene and Noriyuki Nasu, the co-chiefs of Leg 57, for making the samples available for study and contributing productive and enjoyable atmosphere aboard the D/V Glomar Challenger. Jack G. Baldauf provided assistance with the photography, and Rose M. Trombley typed the manuscript.

\section{REFERENCES}

Abbot, W. H., 1978. Correlation and zonation of Miocene strata along the Atlantic margin of North America using diatoms and silicoflagellates. Mar. Micropaleont., 3, 1534.

Akiba, F., 1977. Denticula kanayae n. sp. in the Denticula kanayae Zone, a biostratigraphically significant diatom. Japan Petroleum Exploration Company, Technical Research Institute Report, 20 (Nos. 3-4), 126-146.

, 1979. The morphologies of Denticula dimorpha and its allied species, and the Neogene diatom biostratigraphy of Japan. Japan Petroleum Exploration Company, Technical Research Institute Report, 22, 148-189.

Armentrout, J. M., Echols, R. J., and Nash, K. W., 1978. Late Miocene climatic cycles of the Yakataga Formation, Robinson Mountains, Gulf of Alaska area. Correlation of Tropical through High Latitude Marine Neogene Deposits of the Pacific Basin (Vol. XIV): Stanford (Stanford University Press), 3-4.

Barron, J. A., 1973. Late Miocene early Pliocene paleotemperatures for California from marine diatom evidence. Palaeogeog., Palaeoclimatol., Palaeoecol., 14, 277-291.

1976. Revised Miocene and Pliocene diatom biostratigraphy of Upper Newport Bay, Newport Beach, California. Mar. Micropaleont., 1, 27-63.

, in press. Upper Pliocene and Quaternary diatom biostratigraphy of DSDP Leg 54, eastern tropical Pacific. In Hekinian, R., Rosendahl, B. R., et al., Init. Repts. DSDP, 54: Washington (U.S. Govt. Printing Office).

Bukry, D., 1973a. Low-latitude coccolith biostratigraphic zonation. In Edgar, N. T., Saunders, J. B., et al., Init. Repts. DSDP, 15: Washington (U.S. Govt. Printing Office), 685-703. 1973b. Coccolith and silicoflagellate stratigraphy, Deep Sea Drilling Project Leg 18, eastern North Pacific. In Kulm, L. D., von Huene, R., et al., Init. Repts. DSDP, 18: Washington (U.S. Govt. Printing Office), 817-831. 1976. Silicoflagellate and coccolith stratigraphy of the Norwegian-Greenland Sea, Deep Sea Drilling Project Leg 38. In Talwani, M., Udintsev, G., et al.. Init. Repts. DSDP, 38: Washington (U.S. Govt. Printing Office), 843855.

Burckle, L. H., 1972. Late Cenozoic planktonic diatom zones from the eastern equatorial Pacific. Nova Hedwigia Beih, $39,217-246$.

1977. Pliocene and Pleistocene diatom datum levels from the equatorial Pacific. Quat. Geol., 7, 330-340.

, 1978. Early Miocene to Pliocene diatom datum levels for the equatorial Pacific. Geol. Soc. Indonesia Proc., IGCP Project 114 Meetings, Indonesia, 1977. Geol. Res. Devel. Cent., Spec. Publ., 1, 25-44.

Burckle, L. H., and Opdyke, N., 1977. Late Neogene diatom correlations in the circum-Pacific. Proceedings of the First International Congress on Pacific Neogene Stratigraphy: Tokyo (Kaiyo Shuppan), 255-284.

Burckle, L. H., and Trainer, J., in press. Middle and late Pliocene diatom datum levels from the central Pacific. Micropaleontology.
Ciesielski, P. F., Dinkelman, M. G., Ledbetter, M. T., and Ellwood, B. B., 1978. New evidence on the timing of late Miocene-middle Pliocene glacial fluctuations from the southwest Atlantic sector of the Southern Ocean. Geol. Soc. Am. Abstracts with Programs, 10 (No. 7), 380. (Abstract)

Cita, M. B., 1975. The Miocene/Pliocene boundary: History and definition. In Saito, T., and Burckle, L. H. (Eds.), Late Neogene Epoch Boundaries: New York (Micropaleontology Press), pp. 1-30.

Cita, M. B., and Ryan, W. B. F., 1978. The Bou Regreg Section of Morocco: Evidence of a late-Miocene regression. Geol. Soc. Am. Abstracts with Programs, 10 (No. 7), 380. (Abstract)

Donahue, J. G., 1970. Pleistocene diatoms as climatic indicators in North Pacific sediments. Geol. Soc. Am. Mem., $126,121-138$.

Gordon, A. L., 1971. Oceanography of Antarctic waters. In Reid, J. L. (Ed.), Antarctic Oceanology I, Vol. 15: Washington (American Geophysical Union, Antarctic Research Series), 169.

Hanna, G. D., 1932. The diatoms of Sharktooth Hill, Kern County, California. Calif. Acad. Sci. Proc., 4th ser., 20 (No. 6), 161-263.

Haq, B. U., Berggren, W. A., and Van Couvering, J. A., 1977. Corrected age of the Pliocene-Pleistocene boundary. $\mathrm{Na}$ ture, 269, 483-488.

Harper, H. E., Jr., 1977a. Diatom biostratigraphy of the Miocene-Pliocene boundary in marine strata of the CircumNorth Pacific [Ph.D. dissert.]. Harvard University. 1977b. Diatom biostratigraphy. In Ujiie, H., Saito, T., Kent, D. V., Thompson, P. R., Okada, H., Klein, G. deVries, Koizumi, I., Harper, H. E., Jr., and Sato, T., Biostratigraphy, paleomagnetism and sedimentology of late Cenozoic sediments in northwestern Hokkaido, Japan. Natl. Sci. Mus. Bull. Ser. C Geol., 3 (No. 2), 49-102.

Ingle, J. C., Jr., 1973. Summary comments on Neogene biostratigraphy, physical stratigraphy and paleo-oceanography in the marginal northeastern Pacific Ocean. In Kulm, L. D., von Huene, R., et al., Init. Repts. DSDP, 18: Washington (U.S. Govt. Printing Office), 949-960.

1978. Evidence of latest Miocene refrigeration and associated eustatic events in California and the North Pacific. Geol. Soc. Am. Abstracts with Programs, 10 (No. 7), 427. (Abstract)

Jousé, A. P. (Ed.), 1977. Atlas of Microorganisms in Bottom Sediments of the Oceans: Moscow (Nauka).

Keller, G., 1978. Late Neogene climatic oscillations across the mid latitudes of the North Pacific. Geol. Soc. Am. Abstracts with Programs, 10 (No. 7), 433. (Abstract)

Kennett, J. P., 1977. Cenozoic evolution of Antarctic glaciation, the circum-Antarctic Ocean, and their impact on global paleoceanography. J. Geophys. Res., 82 (No. 27), 3843-3860.

1978. The Kapitean (latest Miocene) paleoclimatic event in the South Pacific. Geol. Soc. Am. Abstracts with Programs, 10 (No. 7), 433-434. (Abstract)

Koizumi, I., 1973. The late Cenozoic diatoms of Sites 183-193, Leg 19, Deep Sea Drilling Project. In Creager, J. S., Scholl, D. W., et al., Init. Repts. DSDP, 19: Washington (U.S. Govt. Printing Office), 805-855.

1975a. Neogene diatoms from the western margin of the Pacific Ocean, Leg 31, Deep Sea Drilling Project. In Karig, D. E., Ingle, J. C., Jr., et al., Init. Repts. DSDP, 31: Washington (U.S. Govt. Printing Office), 779-819.

1975b. Late Cenozoic diatom biostratigraphy in the circum-North Pacific region. Geol. Soc. Japan J., 81 (No. $10), 611-627$. 
1975c. Neogene diatoms from the northwestern $\mathrm{Pa}$ cific Ocean, Deep Sea Drilling Project. In Larson, R. L., Moberly, R., et al., Init. Repts. DSDP, 32: Washington (U.S. Govt. Printing Office), 865-889.

1975d. Diatom events in late Cenozoic deep sea sequences in the North Pacific. Geol. Soc. Japan J., 81 (No. 9), 567-578.

1977. Diatom biostratigraphy in the North Pacific region. Proceedings of the First International Congress on Pacific Neogene Stratigraphy: Tokyo (Kaiyo Shuppan), pp. 235-253.

in press. Neogene diatoms from the Emperor Seamount Chain, Leg 55, Deep Sea Drilling Project. In Koizumi, I., Jackson, E. D., et al., Init. Repts. DSDP, 55: Washington (U.S. Govt. Printing Office).

LaBrecque, J. L., Kent, D. V., and Cande, S. C., 1977. Revised magnetic polarity time scale for Late Cretaceous and Cenozoic time. Geology, 5, 330-335.

Ling, H. Y., 1977. Late Cenozoic silicoflagellates and ebridians from the eastern North Pacific. Proceedings of the First International Congress on Pacific Neogene Stratigraphy: Tokyo (Kaiyo Shuppan), 205-233.

MacDougall, I., Saemundsson, K., Johannesson, H., Watkins, N. D., and Kristjansson, I., 1977. Extension of the geomagnetic polarity time scale to $6.5 \mathrm{~m} . \mathrm{y} . \mathrm{K}-\mathrm{Ar}$ dating, geological and paleomagnetic study of a 3,500-m lava succession in western Iceland. Geol. Soc. Am. Bull., 88, 1-15.

Martini, E., 1971. Standard Tertiary and Quaternary calcareous nannoplankton zonation. In Farinacci, A. (Ed.), Proceedings of the Second Planktonic Conference, Roma, 1970 (Vol. 2): Rome (Ediziomi Tecnoscienza), 739-777.

Ryan, W. B. F., Cita, M. B., Rawson, M., Burckle, L. H., and Saito, T., 1974. A paleomagnetic assignment of Neogene stage boundaries and the development of isochronous datum planes between the Mediterranean, the Pacific and Indian Oceans in order to investigate the response of the world ocean to the Mediterranean "salinity crisis." Riv. Ital. Paleontol., 80, 631-688.

Schrader, H.-J., 1973. Cenozoic diatoms from the northeast Pacific, Leg 18. In Kulm, L. D., von Huene, R., et al., Init. Repts. DSDP, 18: Washington (U.S. Govt. Printing Office), 673-797.

1974. Cenozoic marine planktonic diatom stratigraphy of the tropical Indian Ocean. In Fisher, R. L., Bunce, E. T., et al., Init. Repts. DSDP, 24: Washington (U.S. Govt. Printing Office), 887-967.

Schrader, H.-J., 1976. Cenozoic planktonic diatom biostratigraphy of the southern Pacific Ocean. In Hollister, C. D., Craddock, C., et al., Init. Repts. DSDP, 35: Washington (U.S. Govt. Printing Office), 605-671.

Schrader, H.-J., and Fenner, J., 1976. Norwegian diatom biostratigraphy and taxonomy. In Talwani, M., Udintsev, G., et al., Init. Repts. DSDP, 38: Washington (U.S. Govt. Printing Office), 921-1098.

Shackleton, N. J., and Opdyke, N. D., 1976. Oxygen-isotope and paleomagnetic stratigraphy of Pacific core V28-239, late Pliocene to latest Pliocene. Geol. Soc. Am. Mem., 145, 449-464.

1977. Oxygen isotope and paleomagnetic evidence for early Northern Hemisphere glaciation. Nature, 20 (No. 5634), 216-219.

Sheshukova-Poretzkaya, V. S., 1967. Neogene marine diatoms of Sakhalin and Kamtschatka: Leningrad (University of Leningrad Press), pp. 1-327, pls. 1-50. (in Russian)

Van Couvering, J. A., Berggren, W. A., Drake, R. F., Aguirre, F., and Curtis, G. H., 1976. The terminal Miocene event. Mar. Micropaleont., 1, 263-286.
Wornardt, W. W., Jr., 1967. Miocene and Pliocene marine diatoms from California. Calif. Acad. Sci. Occas. Pap., 63, $1-108$.

\section{APPENDIX \\ Description of a New Diatom Taxon}

\section{Genus THALASSIOSIRA Cleve (1873) emend. Hasle (1973)}

Thalassiosira nidulus var. delicata Barron, $\mathrm{n}$. var.

Description: Valves circular, 14 to $40 \mu \mathrm{m}$ in diameter, flat across the center with depressed margins. Margins distinctive (about $2 \mu \mathrm{m}$ wide), with prominent marginal spines (about $1.5 \mu \mathrm{m}$ long) which bifurcate at their end to a $1.5-\mu \mathrm{m}$ width. Spines distributed about 3.5 in $10 \mu \mathrm{m}$. Subrounded areolae arranged in radial, linear rows which terminate toward the center of the valve with a small pore. Areolae increase in size toward the margin and range from about 9 to 13 in 10 $\mu \mathrm{m}$.

Discussion: This variety is generally more delicate in appearance than T. nidulus var. nidulus (Tempère and Brun) Jousé. The margin is not as prominent, the areolae are smaller, and the radial, linear pattern of the areolae is better developed. Compare Figures 4 and 5 of Plate 6.

Holotype: Plate 6, Figure 1, 32- $\mu \mathrm{m}$ diameter, DSDP 438A-20-4, $135-137 \mathrm{~cm}(245.4 \mathrm{~m})$, USNM 689960.

Isotope: Plate 6 , Figure $4,33-\mu \mathrm{m}$ diameter, DSDP 438A-34-5, $85-87 \mathrm{~cm}(379.4 \mathrm{~m})$, USNM 689961.

Occurrences: Thalassiosira nidulus var. delicata occurs in the lower Pliocene and upper Miocene Denticula kamtschatica Zone at DSDP Sites 438 and 440 off northeast Japan.

\section{Taxonomic Notes and Illustration References}

Actinocyclus ingens Rattray: Schrader, 1973, pl. 18, figs. 2-4, 7. (Plate 5, Figure 2)

Actinocyclus ingens var. 1: Synonym: Actinocyclus ingens, Jousé, 1977, pl. 53, fig. 1. Remarks: This variety is characterized by an undulating valve surface; the central area and a submarginal ring rise to an equal elevation. (Plate 5, Figures 8, 12)

Actinocyclus ingens var. 2: Synonym: Actinocyclus ingens, Sheshukova-Poretzkaya, 1967, pl. 30, fig. 1a. Remarks: This form is also characterized by an undulating valve surface, but the central area is depressed relative to the raised submarginal ring.

Actinocyclus ochotensis Jousé: Koizumi, 1973, pl. 2, figs. 3-7.

Actinocyclus oculatus Jousé: Koizumi, 1973, pl. 2, figs. 8, 9. Remarks: Small specimens with a large hyaline central area closely resemble Cosmiodiscus insignis Jousé. (Plate 5, Figures 1,3)

Actinoptychus minutus Greville: Barron, 1976, pl. 1, fig. 2.

Annellus californicus Tempère in Tempère and Peragallo: Hanna, 1932, pl. 4, figs. 5-9.

Asterolampra acutiloba Forti in Tempère and Peragallo: Schrader, 1974, pl. 9, figs. 7, 8. (Plate 3, Figure 9).

Bacteriosira fragilis Gran: Schrader, 1973, pl. 16, fig. 7.

Coscinodiscus endoi Kanaya: Schrader, 1973, pl. 7, figs. 14, 21; pl. 20, figs. 1, 2. (Plate 4, Figure 6)

Coscinodiscus lewisianus Greville: Schrader, 1973, pl. 8, figs. 1-6, 10, 15. (Plate 3, Figure 10)

Coscinodiscus sp. aff. C. marginatus Ehrenberg, of Schrader, 1976, pl. 10, fig. 3 .

Coscinodiscus plicatus Grunow s. ampl.: Schrader and Fenner, 1976, pl. 15, figs. 5, 8, 9, 11-13. Remarks: A broad concept of this species that includes several varieties of plicate Coscinodiscus, not otherwise separated, is used in this chapter. (Plate 3, Figure 12)

Coscinodiscus praeyabei Schrader, 1973, pl. 6, fig. 16; pl. 7, figs. $17-20,22,23$

Coscinodiscus pustulatus Mann: Koizumi, 1973, pl. 4, figs. 1-4. (Plate 5, Figure 10)

Coscinodiscus ruboides Schrader, 1976, pl. 6, figs. 4, 8.

Coscinodiscus symbolophorus Grunow: Remarks: Only the distinctive varieties found in lower middle Miocene and lower Miocene sediments have been recorded.

C. symbolophorus var. 1. Synonym: $C$. symbolophorus group 5 of Schrader, 1976, pl. 4, fig. 4 .

C. symbolophorus var. 2. Synonym:C. symbolophorus group 2 of Schrader, 1976, pl. 7, fig. 2. 
Coscinodiscus temperei Brun in Brun and Tempère: Schrader, 1973, pl. 6, figs. 18, 19; pl. 7, figs. 1-5, 8, 9. Remarks: Larger specimens are more typical of the later forms of this species. (Plate 4, Figure 5)

Coscinodiscus yabei Kanaya: Schrader, 1973, pl. 6, figs. 1-6, 15. (Plate 3, Figure 11)

Cosmiodiscus insignis Jousé: Koizumi, 1973, pl. 4, figs 7-11. (Plate 4, Figure 1)

Cussia paleacea (Grunow) Schrader: Synonym: Coscinodiscus paleaceus Grunow: Burckle, 1972, pl. 1, figs. 7, 8.

Cussia tatsunokuchiensis (Koizumi) Schrader: Koizumi, 1975b, pl. 1, fig. 23; Koizumi, 1975c, pl. 4, figs. 33-35. Remarks: Earlier forms of this species tend to be longer and thinner (Plate 1, Figure 31) than later forms (Plate 1, Figure 31; Plate 4, Figure 3)

Cymatogonia amblyoceras Hanna: Schrader, 1973, pl. 26, fig. 8 .

Delphineis penelliptica Andrews: Abbott, 1978, pl. 1, fig. 6. (Plate 1, Figure 25)

Denticula dimorpha Schrader, 1973, pl. 1, figs. 37-46. (Plate 1, Figure 21)

Denticula hustedtii Simonsen and Kanaya: Schrader, 1973, pl 2, figs, 28-34, 36-47. (Plate 1, Figures 9-11)

Denticula hyalina Schrader, 1973, pl. 1, figs. 12-22. (Plate 1, Figure 12)

Denticula ikebei Akiba, 1977, pl. 1, fig. 15, pl. 2, figs. 1-3. Remarks: Akiba (1977) notes a length of 41 to $63 \mu \mathrm{m}$ and a width of 6.5 to 7 $\mu \mathrm{m}$ for this species. There are 3 pseudosepta in $10 \mu \mathrm{m}$ and 10 to 12 puncta in $10 \mu \mathrm{m}$. The quincunx arrangement is not clear and the apices are rounded. (Plate 1, Figure 30)

Denticula kamtschatica Zabelina: Schrader, 1973, pl. 2, figs. 1-3, 6-13 (4, 5?); Harper, 1977b, pl. 3, figs. 1-4, pl. 5, figs. 1-4, 8. Remarks: According to the type description of Zabelina (1934), $D$. kamtschatica has 5 to 6 pseudosepta per $10 \mu \mathrm{m}$. Harper (1977b) refers specimens resembling $D$. kamtschatica, but having 7 to 11 transapical costae or pseudosepta, to Nitzschia rolandii Schrader emend. Harper (see Harper, 1977b, pl. 3, figs. 9-11; pl. 5, figs 5-7). For purposes of this report, these latter forms are referred to $D$. sp. cf. D. kamtschatica in the occurrence charts (Plate 1, Figures 15-17). Whether they should be referred to Denticula or Nitzschia is presently unclear. (Plate 1, Figures 5-8)

Denticula kanayae Akiba, 1977, pl. 1, figs. 1-10, pl. 2, fig. 13. Remarks: Akiba (1977) states this species is 14 to $43 \mu \mathrm{m}$ in length and 4 to $8 \mu \mathrm{m}$ in width. There are 2 pseudosepta in $10 \mu \mathrm{m}$ and 6 puncta in $10 \mu \mathrm{m}$. The apex is rounded and the quincunx arrangement is unclear. (Plate 1, Figures 26-28)

Denticula lauta Bailey: Schrader, 1973, pl. 2, figs. 14-25, 35. Remarks: Specimens stratigraphically below D. lauta s. str. (Plate 1, Figures 13,14 ) are listed as $D$. sp. cf. $D$. lauta. A synonym of this latter form is D. sp. aff. D. kamtschatica, Schrader, 1976, pl. 4, fig. 18. (Plate 1, Figure 24).

Denticula miocenica Schrader, 1973, pl. 2, figs. 26-28.

Denticula nicobarica Grunow: Schrader, 1976, pl. 4, figs. 19-21. Remarks: Denticula paranicobarica of Akiba, 1977, pl. 1, figs. $11-14$, is included here for the purposes of this report. (Plate 1, Figures 22, 23)

Denticula norwegica Schrader: Schrader and Fenner, 1976, pl. 1, fig. 38.

Denticula praedimorpha Akiba, 1979. Remarks: Akiba (in press) separates this species from D. dimorpha Schrader (1973) on the basis of the presence of secondary pseudosepta near the apex and cross-bars that are not united to a septum. (Plate 1, Figures 18-20)

Denticula punctata Schrader, 1973, pl. 1, figs. 25-30.

Denticula punctata var. hustedtii Schrader, 1973, pl. 1, figs. 23, 24. (Plate 1, Figure 29)

Denticula seminae Simonsen and Kanaya: Koizumi, 1975b, pl. 1, figs. 1, 2. (Plate 1, Figure 1)

Denticula seminae var. fossilis Schrader: Koizumi, 1975b, pl. 1, figs. 3, 4. (Plate 1, Figures 2-4)

Goniothecium tenue Brun: Koizumi, 1973, pl. 7, figs. 7-9. (Plate 4, Figure 2)

Hemidiscus cuneiformis Wallich: Schrader, 1973, pl. 24, fig. 14. Remarks: Also included here is $H$. simplicissimus of Schrader, 1973, pl. 24, figs. 12, 13. (Plate 3, Figure 13)

Kisselviella carina Sheshukova-Poretzkaya: Koizumi, 1973, pl. 7. figs. 3, 4. Remarks: Compare Cymatospira spp. of Schrader and Fenner, 1976. (Plate 1, Figure 32).
Lithodesmium cornigerum Brun: Wornardt, 1967, fig. 131.

Lithodesmium reynoldsii Barron, 1976, pl. 1, figs. 17, 18. (Plate 4, Figure 10)

Mediaria splendida Sheshukova-Poretzkaya: Schrader, 1973, pl. 3, figs. 14, 15. Remarks: Generally observed as fragments.

Nitzschia challengeri Schrader, 1973, pl. 5, figs. 10-14, 34. (Plate 2, Figure 10)

Nitzschia fossilis (Frenguelli) Kanaya: Schrader, 1973, pl. 4, figs. $4,5,9-11,24,25$. (Plate 2, Figures 3, 4)

Nitzschia heteropolica Schrader, 1973, pl. 26, figs. 1, 2. (Plate 2, Figure 7; Plate 4, Figure 9)

Nitzschia jouseae Burckle: Schrader, 1974, pl. 7, figs. 14-23. (Plate 3, Figure 2)

Nitzschia marina Grunow in Cleve and Grunow: Schrader, 1973, pl. 4 , figs. 17-19.

Nitzschia miocenica Burckle: Schrader, 1974, pl. 5, figs. 10-11. Remarks: In his type description, Burckle (1972) states that the number of costae of $N$. miocenica is quite "regular, generally within the range of ten to eleven per ten microns." Younger forms of this taxon, however, seem to be somewhat finer in structure than older forms. (Plate 2, Figure 8; Plate 3, Figures 3, 4)

Nitzschia pliocena (Brun) Kanaya and Koizumi: Harper, 1977b, pl. 3, figs. 16, 17. Synonym: Fragilariopsis pliocena, SheshukovaPoretzkaya, 1967, pl. 47, fig. 13. (Plate 2, Figures 1, 2)

Nitzschia porteri Frenguelli, sensu Burckle, 1972, pl. 2, fig. 16. (Plate 2, Figure 9; Plate 3, Figure 5)

Nitzschia praereinholdii Schrader, 1973, pl. 5, figs. 20, 23-26. Remarks: Younger forms of this taxon tend to be more finely silicified and finer in structure than earlier forms.

Nitzschia reinholdii Kanaya and Koizumi: Schrader, 1973, pl. 4, figs. 12-16, pl. 5, figs. 1-9. (Plate 2, Figure 11; Plate 3, Figure 1)

Porosira glacialis (Grunow) Joergensen: Koizumi, 1973, pl. 4, figs. 15-18. (Plate 6, Figure 13)

Pseudoeunotia doliolus (Wallich) Grunow in Van Heurck: Schrader, 1973 , pl. 4, figs. 1, 3, 6-8. (Plate 2, Figure 5)

Rhaphoneis miocenica Schrader, 1973, pl. 25, figs. 1, 11.

Rhizosolenia barboi Brun: Schrader, 1973, pl. 24, figs. 4, 7. Synonym: $R$. curvirostris var. inermis, Koizumi, 1973, pl. 5, figs. 32, 33. (Plate 2, Figure 17)

Rhizosolenia curvirostris Jousé: Koizumi, 1973, pl. 5, figs. 29-31. (Plate 2, Figure 12)

Rhizosolenia hebeata f. hiemalis Gran: Koizumi, 1973, pl. 5, figs. 34, 35; Schrader, 1973, pl. 9, figs. 14-17. (Plate 2, Figure 15)

Rhizosolenia miocenica Schrader, 1973, pl. 10, figs. 2-6, 9-11. (Plate 4, Figure 8)

Rhizosolenia praebarboi Schrader, 1973, pl. 24, figs. 1-3. (Plate 2, Figure 18)

Rhizosolenia praebergonii Mukhina: Burckle, 1972, pl. 1, fig. 1. (Plate 2, Figure 16)

Rhizosolenia praebergonii var. robusta Burckle and Trainer, in press: Synonym: $R$. praebergonii, Schrader, 1974, pl. 9, figs. 1-3; Burckle, 1972, pl. 1, figs. 2, 3 .

Roperia tesselata (Roper) Grunow in Van Heurck: Schrader, 1973, pl. 19 , figs. 8,9 .

Rouxia californica Peragallo in Tempère and Peragallo: Schrader, 1973, pl. 3, figs. 18-20, 22, 26. Remarks: A broad concept of this species is followed here. (Plate 4, Figure 4)

Stephanopyxis horridus Koizumi: Koizumi, 1973, pl. 6, figs. 1-4. (Plate 5, Figure 13)

Stephanopyxis hyalomarginata Hajos: Schrader and Fenner, 1976, pl. 19, figs. 6,9 .

Stephanopyxis schenckii Kanaya: Schrader and Fenner, 1976, pl. 19, figs. 7,8 .

Synedra jouseana Sheshukova-Poretzkaya: Schrader, 1973, pl. 23, figs. 21-23, 25, 38. (Plate 2, Figures 13, 14)

Synedra jouseana var. 1: Synonym: Thalassionema hirosakiensis, Schrader and Fenner, 1976, pl. 5, figs. 3, 4, 6, 7; Schrader, 1976, pl. 1, figs. 14-16. Remarks: Generally more robust than other forms referred to the species in Leg 57 samples. (Plate 1, Figure 33)

Thalassionema hirosakiensis (Kanaya) Schrader, 1973, pl. 23, figs. 31-33. (Not T. hirosakiensis, Schrader, 1976, pl. 1, figs 15-16; Schrader and Fenner, 1976, pl. 5, figs. 3, 4, 6, 7. (Plate 2, Figure 6)

Thalassiosira antiqua (Grunow) Cleve-Euler: Schrader, 1973, pl. 11, fig. 25 , pl. 25, fig. 19. (Plate 5, Figure 5) 
Thalassiosira burckliana Schrader, 1974, pl. 1, figs. 21-26. Synonym: T. nativa, Schrader, 1973, pl. 11, figs. 24, 25. (Plate 3, Figure 7) Thalassiosira convexa Mukhina: Schrader, 1974, pl. 2, figs. 1-5, 1013.

Thalassiosira convexa var. aspinosa Schrader, 1974, pl. 2, figs. 8, 9, 13a-21. Synonym: T. convexa, Koizumi, 1975a, pl. 4, figs. 15-18. (Plate 3, Figure 8)

Thalassiosira convexa? var. 1. Remarks: This form has the size and general morphology of $T$. zabelinae Jousé but has a pattern of areolation that closely resembles $T$. convexa. This form probably should be placed under $T$. zabelinae; however, it is placed here because of its similarity to $T$. convexa. Koizumi (1975a) figures this form as T. convexa (pl. 4, figs. 19, 20). (Plate 5, Figure 14; Plate 6, Figure 16)

Thalassiosira fraga Schrader, in Schrader and Fenner, 1976, pl. 16, figs. 9-12.

Thalassiosira gravida Cleve: Koizumi, 1973, pl. 7, figs. 19-21. Remarks: Included for this chapter is $T$. gravida f. fossilis of Koizumi, 1973, pl. 7, figs. 22-24. (Plate 6, Figures 11, 14)

Thalassiosira gravida Cleve (flat form): Synonyms: $T$. gravida, Koizumi, 1972, pl. 43, fig. 11; $T$. aff. margaritae, Sheshukova-Poretzkaya, 1967, pl. 4, fig. 6, pl. 14, fig. 5. Remarks: Specimens of $T$. gravida with flattened valves are tabulated here. (Plate 5, Figure 11; Plate 6, Figure 15)

Thalassiosira hyalina (Grunow) Grunow: Koizumi, 1973, pl. 8, figs. $1,2$.

Thalassiosira jacksonii Koizumi and Barron, in Koizumi, in press, pl. 1, figs. 11-14. (Plate 6, Figures 2, 6, 10?)

Thalassiosira miocenica Schrader, 1974 , pl. 22, figs. 1-5, 11-13. (Plate 3, Figure 6)

Thalassiosira nativa Sheshukova-Poretzkaya, sensu Koizumi, 1975b, pl. 2, fig. 9; Koizumi, 1975a, pl. 4, figs. 21, 22. Synonym: T. decipiens (?), Schrader, 1973, pl. 16, fig. 12. Remarks: Included here are specimens with marginal spines that have recently been separated into a new species, $T$. borealis, by Koizumi, in press. (Plate 6 , Figures $8,9,12$ )
Thalassiosira nidulus (Tempère and Brun) Jousé, var. nidulus: Schrader, 1973, pl. 11, figs. 1-7. Remarks: Miocene specimens are more heavily silicified than younger specimens. (Plate 6, Figure 5)

Thalassiosira oestrupii (Ostenfeld) Proshkina-Lavrenko: Schrader, 1973 , pl. 11, figs. 16-22, 26-33, 36, 39-45. (Plate 5, Figure 4)

Thalassiosira pacifica Gran and Angst: Schrader, 1973, pl. 25, figs. 18, 20, 21. Synonym: Coscinodiscus excentricus var. leasareolatus Koizumi, 1973, pl. 3, figs. 7-11.

Thalassiosira punctata Jousé: Koizumi, 1973, pl. 8, figs. 7-9. (Plate 6, Figure 3)

Thalassiosira spinosa Schrader, 1976, pl. 6, figs 5-7.

Thalassiosira spinosa var. aspinosa Schrader, 1976, pl. 6, fig. 3

Thalassiosira spumellaroides Schrader, 1976, pl. 6, figs. 1, 2.

Thalassiosira zabelinae Jousé: Koizumi, 1973, pl. 8, figs. 10-12. Remarks: Included here is T. usatchevii of Koizumi, 1973, pl. 8, figs. 13-15. (Plate 6, Figure 7)

Thalassiosira sp. 1. Synonym: T. praeconvexa of Schrader, 1973, pl. 11, figs. 10-15. (Plate 5, Figures 6, 7)

Thalassiosira sp. 2. (Plate 5, Figure 9)

\section{Silicoflagellates}

Distephanus boliviensis jimlingii Bukry: Barron, 1976, pl. 3, fig. 31.

Distephanus pseudofibula (Schulz) Bukry: Barron, 1976, pl. 3, fig. 29. Synonym: Dictyocha pseudofibula, Bukry, 1973b, pl. 1, figs. 7-9. (Plate 4, Figure 7)

Mesocena apiculata curvata Bukry, 1976, pl. 2, figs. 15, 16. (Plate 5, Figure 16)

Mesocena hexagona Haeckel: Barron, 1976, pl. 3, figs. 28, 33. (Plate 5, Figure 15)

Mesocena quadrangula Ehrenberg ex Haeckel: Bukry, 1973b, pl. 7, figs. 1-5; Ling, 1977, pl. 3, fig. 5. 


\section{PLATE 1}

Diatoms from DSDP Leg 57 and Japan

(Scale bar represents $20 \mu \mathrm{m}$.)

Figure 1 Denticula seminae Simonsen and Kanaya. Sample 438A-2-1, 96-98 cm.

Figures 2-4 Denticula seminae var. fossilis Schrader.

2. Sample 438A-2-1, 96-98 cm.

3, 4. Sample 438A-5,CC.

Figures 5-8 Denticula kamtschatica Zabelina.

5. Sample 438A-7,CC.

6. Sample 438A-41-5, $90-92 \mathrm{~cm}$.

7. Sample 438A-6,CC.

8. Sample 438A-28-4, $118-120 \mathrm{~cm}$.

Figures 9-11 Denticula hustedtii Simonsen and Kanaya.

9. Sample 438A-33-5, 132-134 cm.

10. Sample 438A-66-2, 25-27 cm.

11. Sample 438A-54-1, 65-67 cm.

Figure 12 Denticula hyalina Schrader. Sample 438A-68-1, 101-103 cm.

Figures 13, 14 Denticula sp. cf. D. lauta Bailey. Sample 438A-85,CC.

Figures 15-17 Denticula sp. cf. D. kamtschatica Zabelina (Nitzschia rolandii of Harper, 1977b).

15. Sample 438A-40,CC.

16. Sample $438 \mathrm{~A}-41-5,90-92 \mathrm{~cm}$.

17. Sample $438 \mathrm{~A}-43-3,123-125 \mathrm{~cm}$.

Figures 18-20 Denticula praedimorpha Akiba.

18, 20. Sample 438A-65-1, 136-137 cm.

19. Sample JDS-3663, Biratori Formation, Umaoi area, Hokkaido, Japan.

Figure 21 Denticula dimorpha Schrader. Sample 438A-57-1, 115-117 cm.

Figures 22, 23 Denticula nicobarica Grunow. Sample 438A-66,CC.

Figure 24 Denticula lauta Bailey. Sample 438A-56-5, 60-62 cm.

Figure 25 Dephineis penelliptica Andrews. Sample 438A-82,CC.

Figures 26-28 Denticula kanayae Akiba.

26, 27. Sample 438B-14,CC.

28. Sample JDS-5675, Tsurikake Formation, Okushiri Island, Hokkaido, Japan.

Figure 29 Denticula punctata var. hustedtii Schrader. Sample 438A-79-1, 55-57 cm.

Figure 30 Denticula ikebei Akiba. Sample 438B-14,CC.

Figure 31 Cussia tatsunokuchiensis (Koizumi) Schrader. Sample 438A-33-5, 132-135 cm.

Figure 32 Kieselviella carina Sheshukova-Poretzkaya. Sample 438A-77-1, 81-83 cm.

Figure 33 Synedra jouseana Sheshukova-Poretzkaya var. 1. Sample 438A-79,CC. 
PLATE 1
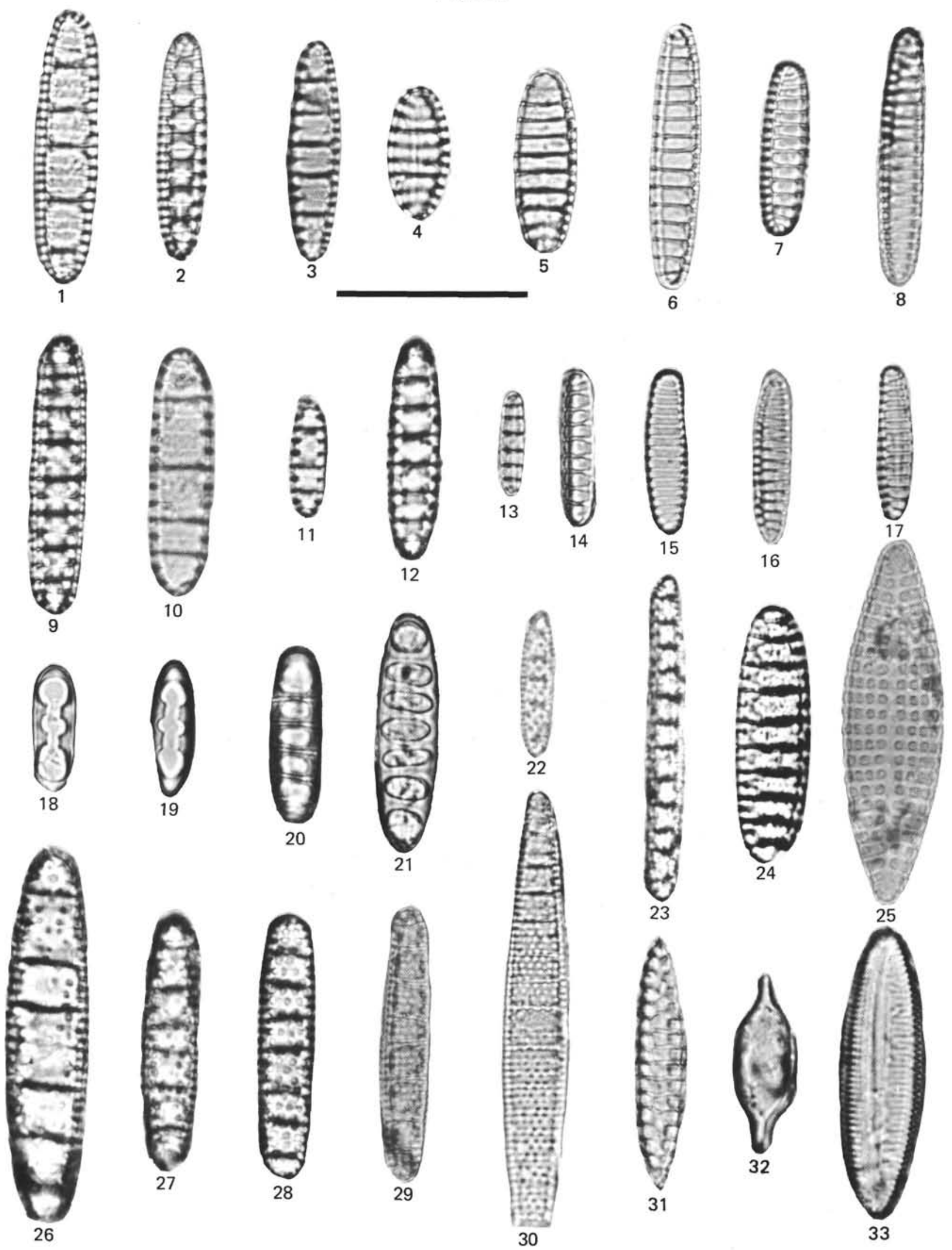


\section{PLATE 2}

Diatoms from DSDP Leg 57

Figures 1, 2 Nitzschia pliocena (Brun) Kanaya and Koizumi. Sample 438A-42-5, 83-85 cm; scale bar represents $15 \mu \mathrm{m}$.

Figures 3, 4 Nitzschia fossilis (Frenguelli) Kanaya.

3. Sample 438A-38-5, 110-112 cm; scale bar represents $15 \mu \mathrm{m}$.

4. Sample 438A-43-3, 123-125 cm; scale bar represents $20 \mu \mathrm{m}$.

Figure 5 Pseudoeunotia doliolus (Wallach) Grunow. Sample 438A-2-1, 96-98 cm; scale bar represents $15 \mu \mathrm{m}$.

Figure 6 Thalassionema hirosakiensis (Kanaya) Schrader. Sample 438A-44-5, 71-73 cm; scale bar represents $15 \mu \mathrm{m}$.

Figure 7 Nitzschia heteropolica Schrader. Sample 438A-64-3, 36-38 cm; scale bar represents $15 \mu \mathrm{m}$.

Figure $8 \quad$ Nitzschia miocenica Burckle. Sample 438A-41-5, 90-92 cm; scale bar represents 15 $\mu \mathrm{m}$.

Figure 9 Nitzschia porteri Frenguelli, sensu Burckle, 1972. Sample 438A-44-5, 71-73 cm; scale bar represents $15 \mu \mathrm{m}$.

Figure $10 \quad$ Nitzschia challengeri Schrader. Sample 438A-66-2, 25-27 cm; scale bar represents 15 $\mu \mathrm{m}$.

Figure 11 Nitzschia reinholdii Kanaya and Koizumi. Sample 438A-28-4, 118-120 cm; scale bar represents $20 \mu \mathrm{m}$.

Figure 12 Rhizosolenia curvirostris Jousé. Sample 438A-3-3, 140-142 cm; scale bar represents $45 \mu \mathrm{m}$.

Figures 13, 14 Synedra jouseana Sheshukova-Poretzkaya.

13. Sample 438A-80,CC; scale bar represents $35 \mu \mathrm{m}$.

14. Sample 438A-43-5, 135-137 cm; scale bar represents $20 \mu \mathrm{m}$.

Figure $15 \quad$ Rhizosolenia hebetata f. hiemalis Gran. Sample 438A-1,CC; scale bar represents 35 $\mu \mathrm{m}$.

Figure 16 Rhizosolenia praebergonii Mukhina. Sample 438A-5,CC; scale bar represents 15 $\mu \mathrm{m}$.

Figure 17 Rhizosolenia barboi Brun. Sample 438A-59,CC; scale bar represents $35 \mu \mathrm{m}$.

Figure 18 Rhizosolenia praebarboi Schrader. Sample 438A-61,CC; scale bar represents $35 \mu \mathrm{m}$. 
PLATE 2
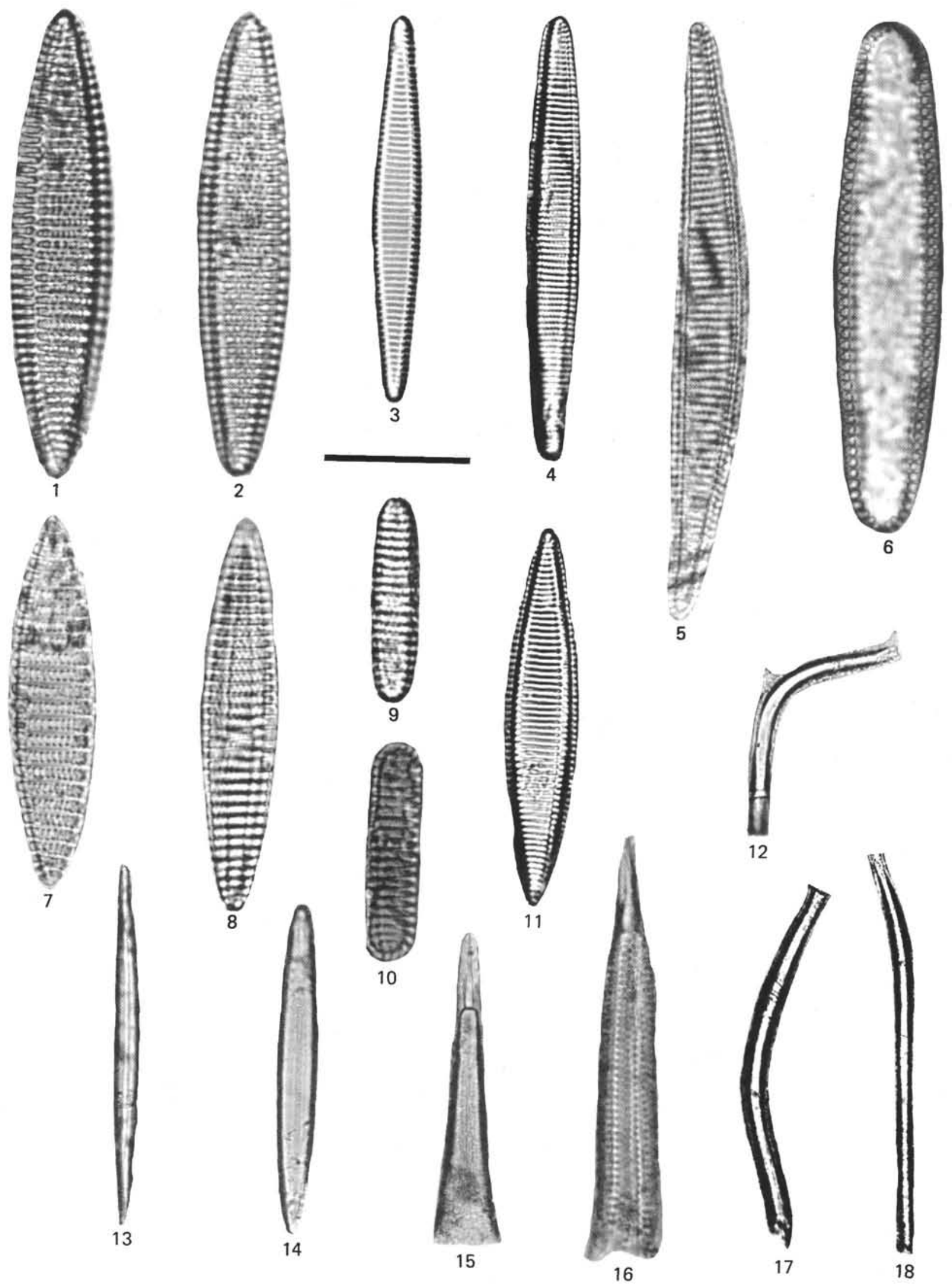
PLATE 3

Diatoms from DSDP Leg 57

Figure $1 \quad$ Nitzschia reinholdii Kanaya and Koizumi. Sample 438-28-4, 118-20 cm; scale bar represents $20 \mu \mathrm{m}$.

Figure 2 Nitzschia jouseae Burckle.

Sample 440B-47,CC: scale bar represents $20 \mu \mathrm{m}$.

Figure 3 Nitzschia miocenica Burckle.

Sample 438A-41,CC: scale bar represents 12.5

$\mu \mathrm{m}$.

Figure $4 \quad$ Nitzschia sp. aff. N. miocenica Burckle.

Sample 438A-39,CC; scale bar represents 12.5

$\mu \mathrm{m}$.

Figure $5 \quad$ Nitzschia porteri Frenguelli, sensu Burckle, 1972. Sample 438A-43-5, 135-137 cm; scale bar represents $12.5 \mu \mathrm{m}$.

Figure 6 Thalassiosira miocenica Schrader.

Sample 438A-38-5, 110-112 cm; scale bar represents $20 \mu \mathrm{m}$.

Figure 7 Thalassiosira burckliana Schrader.

Sample 438A-47-1, 70-72 cm; scale bar represents $12.5 \mu \mathrm{m}$.

Figure $8 \quad$ Thalassiosira convexa var. aspinosa Schrader. Sample 438A-38-3, 130-132 cm; scale bar represents $20 \mu \mathrm{m}$.

Figure $9 \quad$ Asterolampra acutiloba Forti.

Sample 438A-38-5, 110-112 cm; scale bar represents $35 \mu \mathrm{m}$.

Figure 10 Coscinodiscus lewisianus Greville.

Sample 438A-79, CC; scale bar represents $28 \mu \mathrm{m}$.

Figure 11 Coscinodiscus yabei Kanaya.

Sample 438A-53-2, 52-53 cm; scale bar represents $20 \mu \mathrm{m}$.

Figure 12 Coscinodiscus plicatus Grunow s. ampl. Sample 438A-68-1, 101-103 cm; scale bar represents $20 \mu \mathrm{m}$.

Figure 13 Hemidiscus cuneiformis Wallich. Sample 438A-35-5, 135-137 cm; scale bar represents $20 \mu \mathrm{m}$. 
PLATE 3
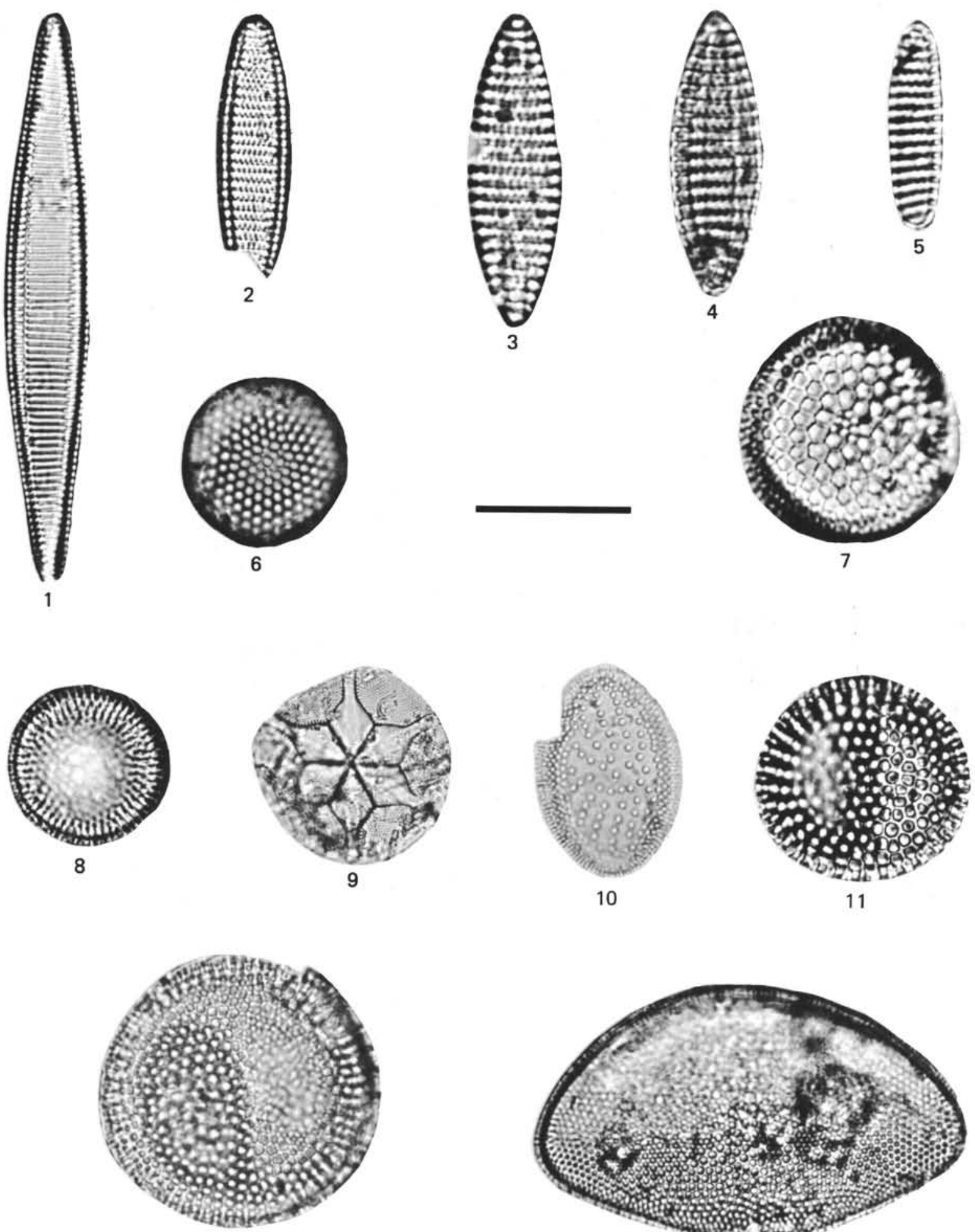

12

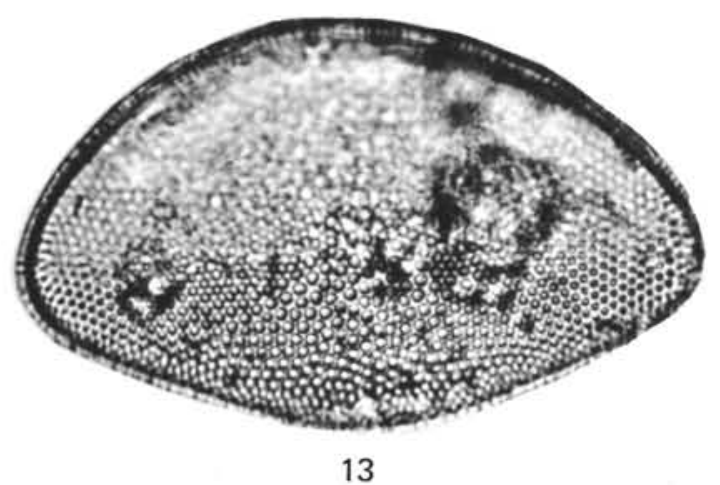




\section{PLATE 4}

Diatoms and Silicoflagellates from DSDP Leg 57

Figure $1 \quad$ Cosmiodiscus insignis Jousé.

Sample 438A-41-1, 140-144 cm; scale bar represents $20 \mu \mathrm{m}$.

Figure 2 Goniothecium tenue Brun.

Sample 438A-36-5, 82-82 cm; scale bar represents $20 \mu \mathrm{m}$.

Figure 3 Cussia tatsunokuchiensis (Koizumi) Schrader. Sample 438A-28-4, 118-120 cm; scale bar represents $12.5 \mu \mathrm{m}$.

Figure $4 \quad$ Rouxia californica Peragallo s. ampl.

Sample 438A-42-1, 80-82 cm; scale bar represents $20 \mu \mathrm{m}$.

Figure $5 \quad$ Coscinodiscus temperei Brun.

Sample 438A-42-1, 80-82 cm; scale bar represents $20 \mu \mathrm{m}$.

Figure 6 Coscinodiscus endoi Kanaya.

Sample 438A-53-2, 52-53 cm; scale bar represents $20 \mu \mathrm{m}$.

Figure 7 Distephanus pseudofibula (Schulz) Bukry. Sample 438A-47-1, 70-72 cm; scale bar represents $30 \mu \mathrm{m}$.

Figure $8 \quad$ Rhizosolenia miocenia Schrader.

Sample 438A-53-2, 52-53 cm; scale bar represents $20 \mu \mathrm{m}$.

Figure $9 \quad$ Nitzschia heteropolica Schrader.

Sample 438A-64-3, 36-38 cm; scale bar represents $20 \mu \mathrm{m}$.

Figure $10 \quad$ Lithodesmium reynoldsii Barron.

Sample 438A-55-1, 30-32 cm; scale bar represents $20 \mu \mathrm{m}$. 


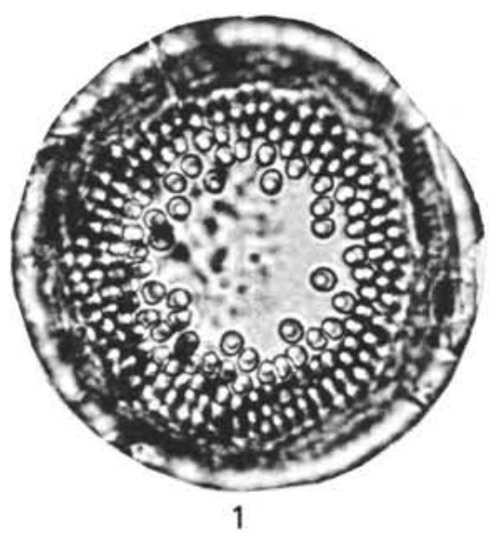

PLATE 4
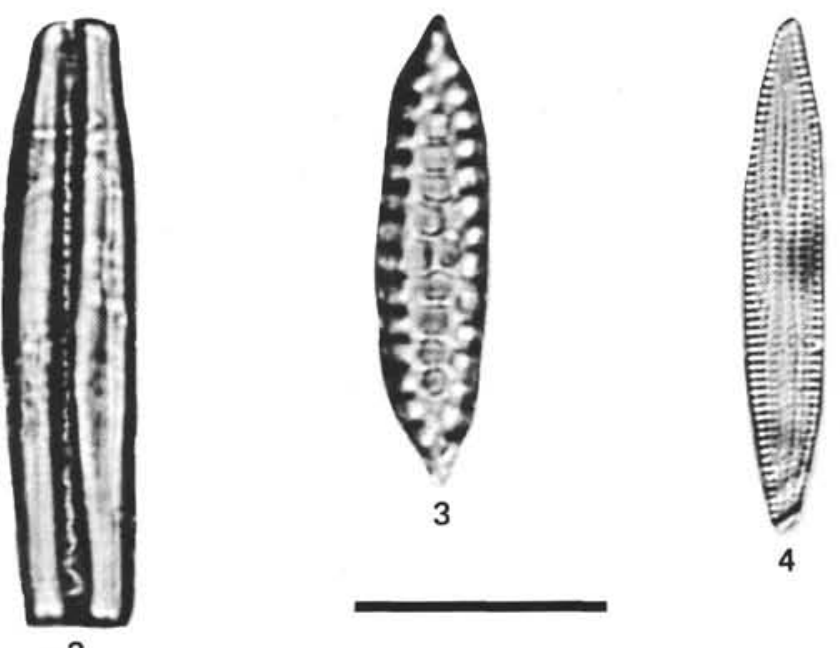

2
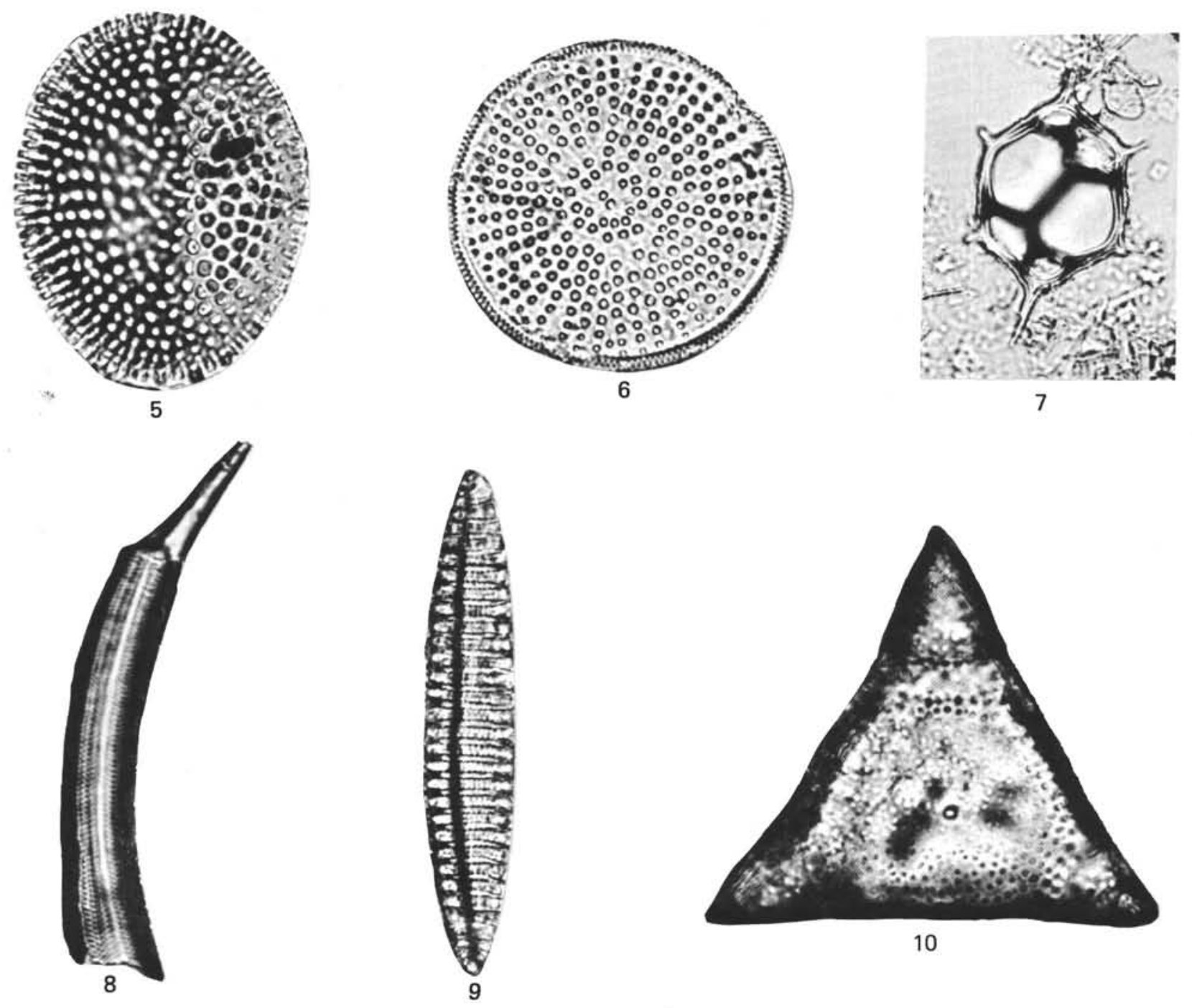
PLATE 5

Diatoms and Silicoflagellates from DSDP Leg 57

Figures 1, 3 Actinocyclus oculatus Jousé.

Sample 438A-4-2, 140-142 cm; scale bar represents $20 \mu \mathrm{m}$.

Figure 2 Actinocyclus ingens Rattray.

Sample 438A-79-1, 55-57 cm; scale bar represents $20 \mu \mathrm{m}$.

Figure 4 Thalassiosira oestrupii (Ostenfeld) Proshkina-Lavrenko.

Sample 438A-32-1, 124-126 cm; scale bar represents $15 \mu \mathrm{m}$.

Figure 5 Thalassiosira antiqua (Grunow) Cleve-Euler.

Sample 438A-42-5, 83-85 cm; scale bar represents $15 \mu \mathrm{m}$.

Figures 6, 7 Thalassiosira sp. 1 (T. praeconvexa of Schrader, 1973).

6. Sample 438A-56,CC; scale bar represents $20 \mu \mathrm{m}$.

7. Sample 438A-53-1, 110-112 cm; scale bar represents $20 \mu \mathrm{m}$.

Figures 8, 12 Actinocyclus ingens var. 1 .

Sample 438A-70-5, 121-123 cm; scale bar represents $35 \mu \mathrm{m}$.

Figure 9 Thalassiosira sp. 2.

Sample 438B-14,CC: scale bar represents $15 \mu \mathrm{m}$.

Figure 10 Coscinodiscus pustulatus Mann.

Sample 438A-5-4, 115-117 cm; scale bar represents $35 \mu \mathrm{m}$.

Figure 11 Thalassiosira gravida Cleve (flat form).

Sample 438A-32-3, 124-126 cm; scale bar represents $35 \mu \mathrm{m}$.

Figure 13 Stephanopyxis horridus Koizumi.

Sample 438-7-6, 20-24 cm; scale bar represents $35 \mu \mathrm{m}$.

Figure 14 Thalassiosira convexa Mukhina? var. 1.

Sample 438A-15-1, 44-46 cm; scale bar represents $35 \mu \mathrm{m}$.

Figure 15 Mesocena hexagona Haeckel.

Sample 438A-60,CC; scale bar represents $45 \mu \mathrm{m}$.

Figure $16 \quad$ Mesocena apiculata curvata Bukry.

Sample 438B-14,CC; scale bar represents $45 \mu \mathrm{m}$. 
PLATE 5
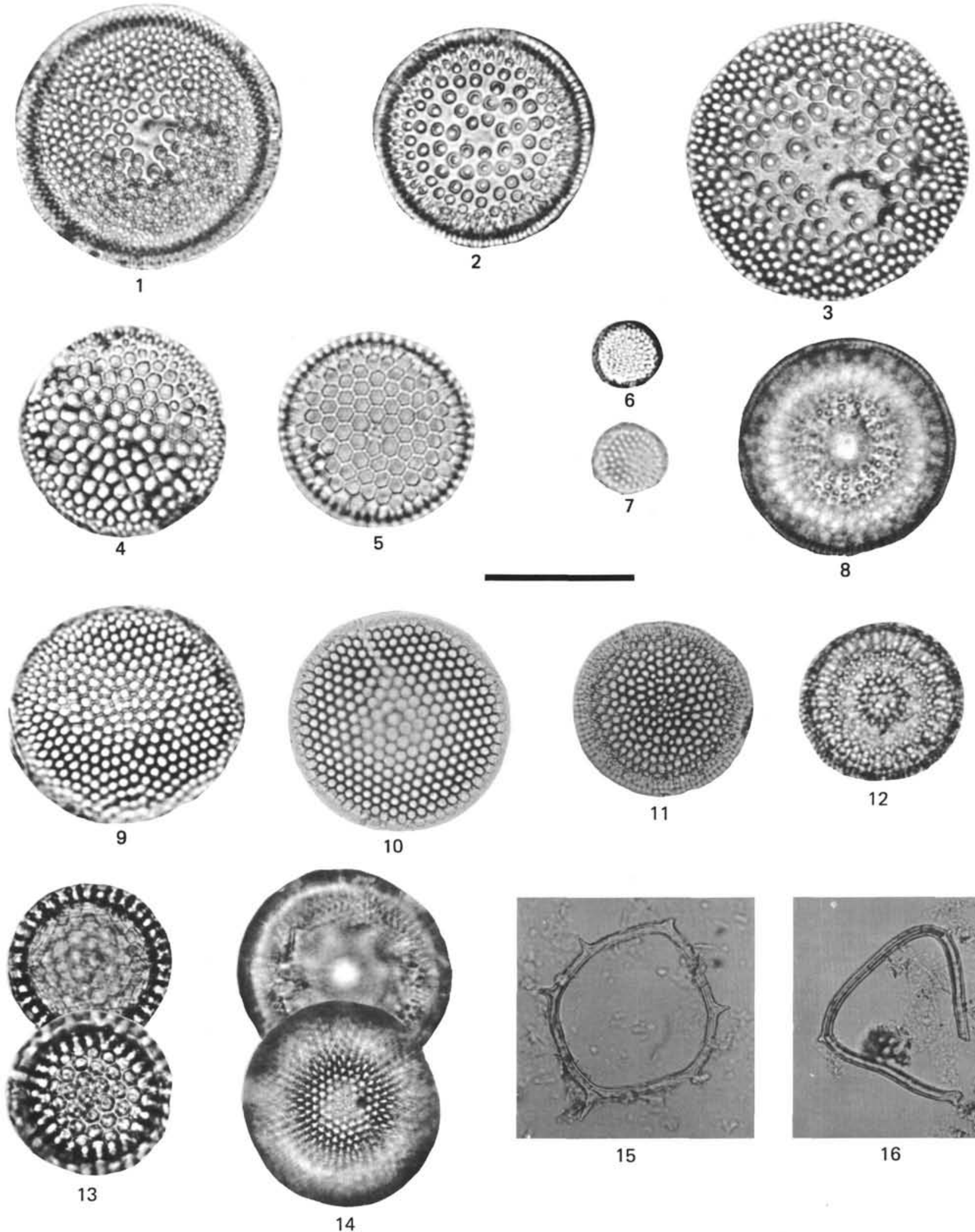

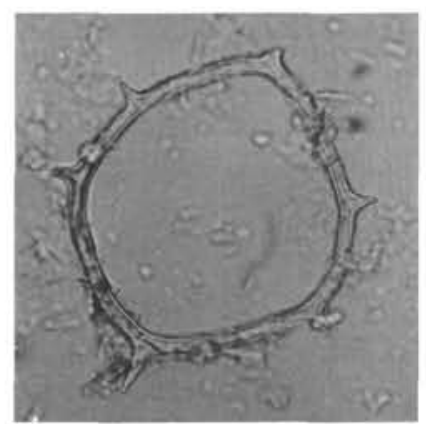

15
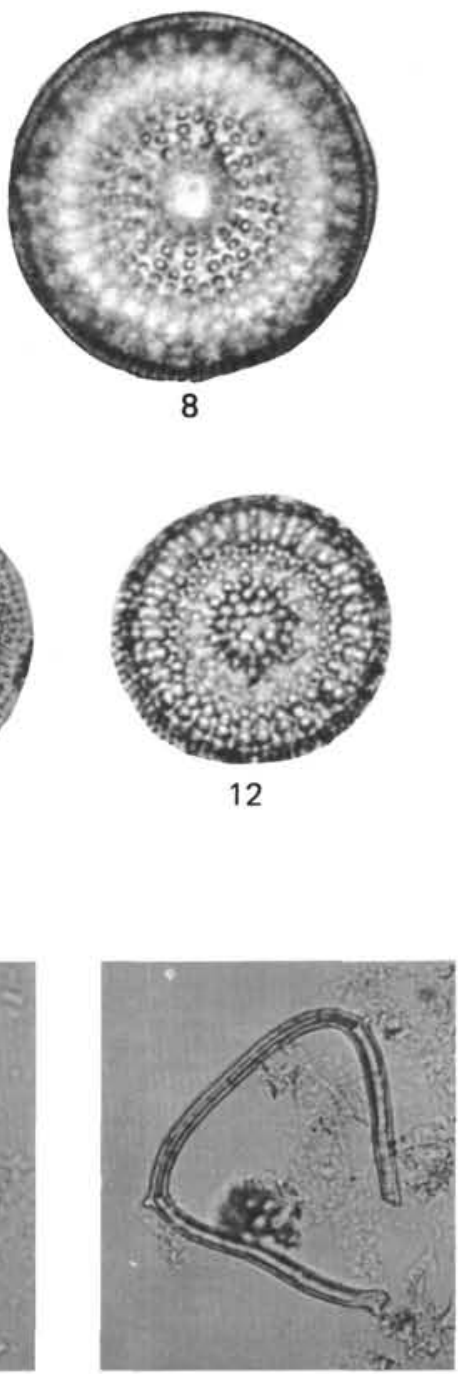

16 


\section{PLATE 6}

\section{Diatoms from DSDP Leg 57}

Figures 1, 4 Thalassiosira nidulus var. delicata $\mathrm{n}$. var.

1. Sample 438A-20-4, 135-137 cm (Holotype USNM 689960); scale bar represents $20 \mu \mathrm{m}$.

4. Sample 438A-34-5, 85-86 cm (Isotype USNM 689961); scale bar represents $35 \mu \mathrm{m}$.

Figures 2, 6 Thalassiosira jacksonii Koizumi and Barron.

2. Sample 438A-31,CC; scale bar represents $15 \mu \mathrm{m}$.

6. Sample 438A-34,CC; scale bar represents $20 \mu \mathrm{m}$.

Figure 3 Thalassiosira punctata Jousé.

Sample 438A-32-1, 124-126 cm; scale bar represents $20 \mu \mathrm{m}$.

Figure 5 Thalassiosira nidulus (Tempère and Brun) Jousé var. nidulus. Sample 438-5-1, 140-142 cm; scale bar represents $20 \mu \mathrm{m}$.

Figure 7 Thalassiosira zabelinae Jousé.

Sample 438A-28-4, 118-120 cm; scale bar represents $20 \mu \mathrm{m}$.

Figures 8, 9, Thalassiosira nativa Sheshukova-Poretzkaya.

12

Sample 438A-20-4, 135-137 cm; scale bar represents $20 \mu \mathrm{m}$.

Figure $10 \quad$ Thalassiosira sp. aff. T. jacksonii Koizumi and Barron.

Sample 438A-30-3, 129-131 cm; scale bar represents $45 \mu \mathrm{m}$.

Figures 11, 14 Thalassiosira gravida Cleve.

11. Sample 438A-2-1, 96-98 cm; scale bar represents $20 \mu \mathrm{m}$.

14. Sample 438A-30-3, 129-131 cm; scale bar represents $20 \mu \mathrm{m}$.

Figure 13 Porosira glacialis (Grunow) Joergensen.

Sample 438A-2-1, 96-98 cm; scale bar represents $20 \mu \mathrm{m}$.

Figure 15 Thalassiosira gravida Cleve (flat form).

Sample 438A-42-3, 110-112 cm; scale bar represents $20 \mu \mathrm{m}$.

Figure 16 Thalassiosira convexa Mukhina? var. 1.

Sample 438A-14,CC; scale bar represents $45 \mu \mathrm{m}$. 
PLATE 6
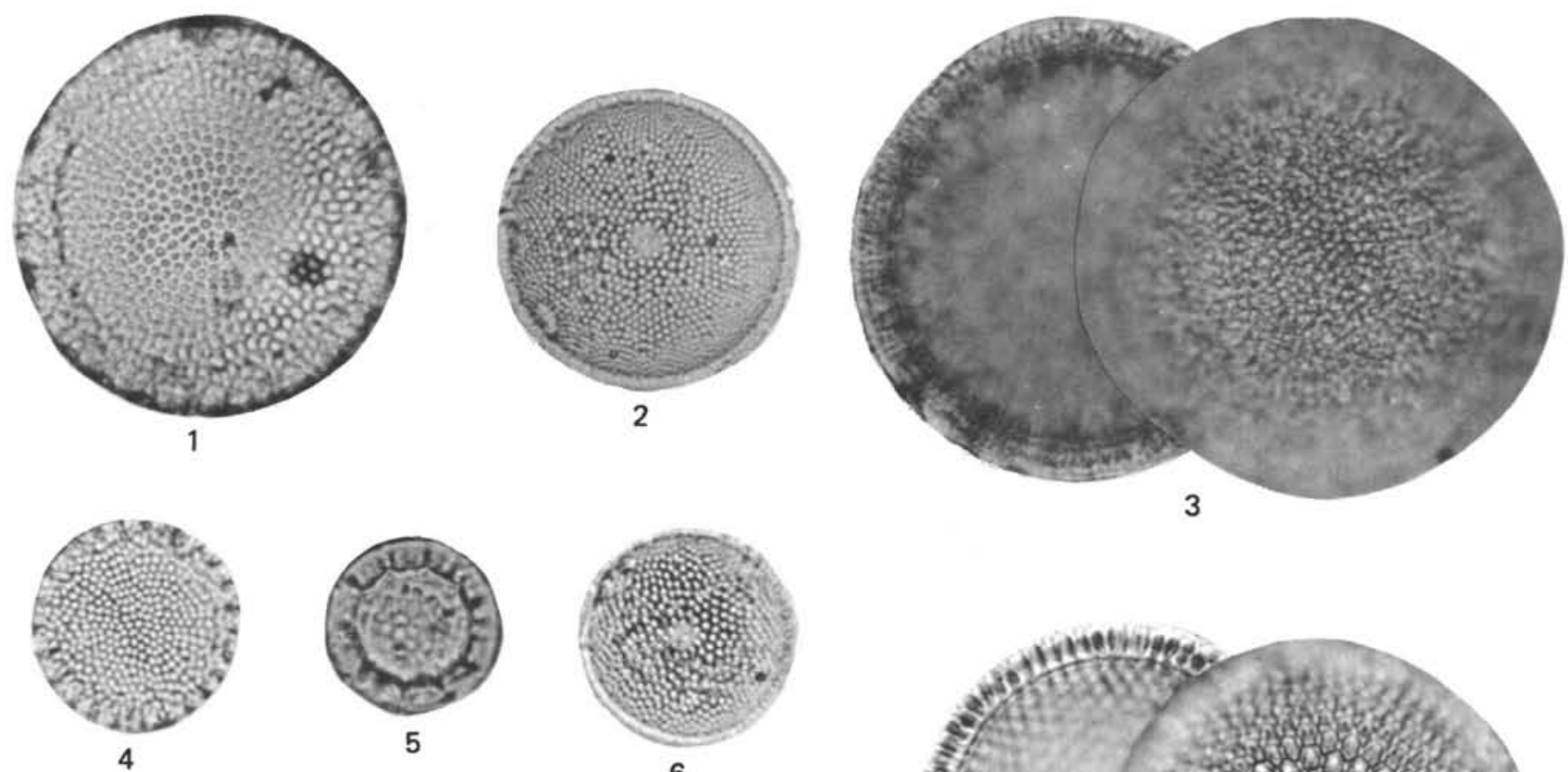

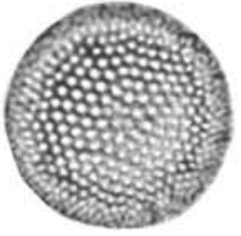

8
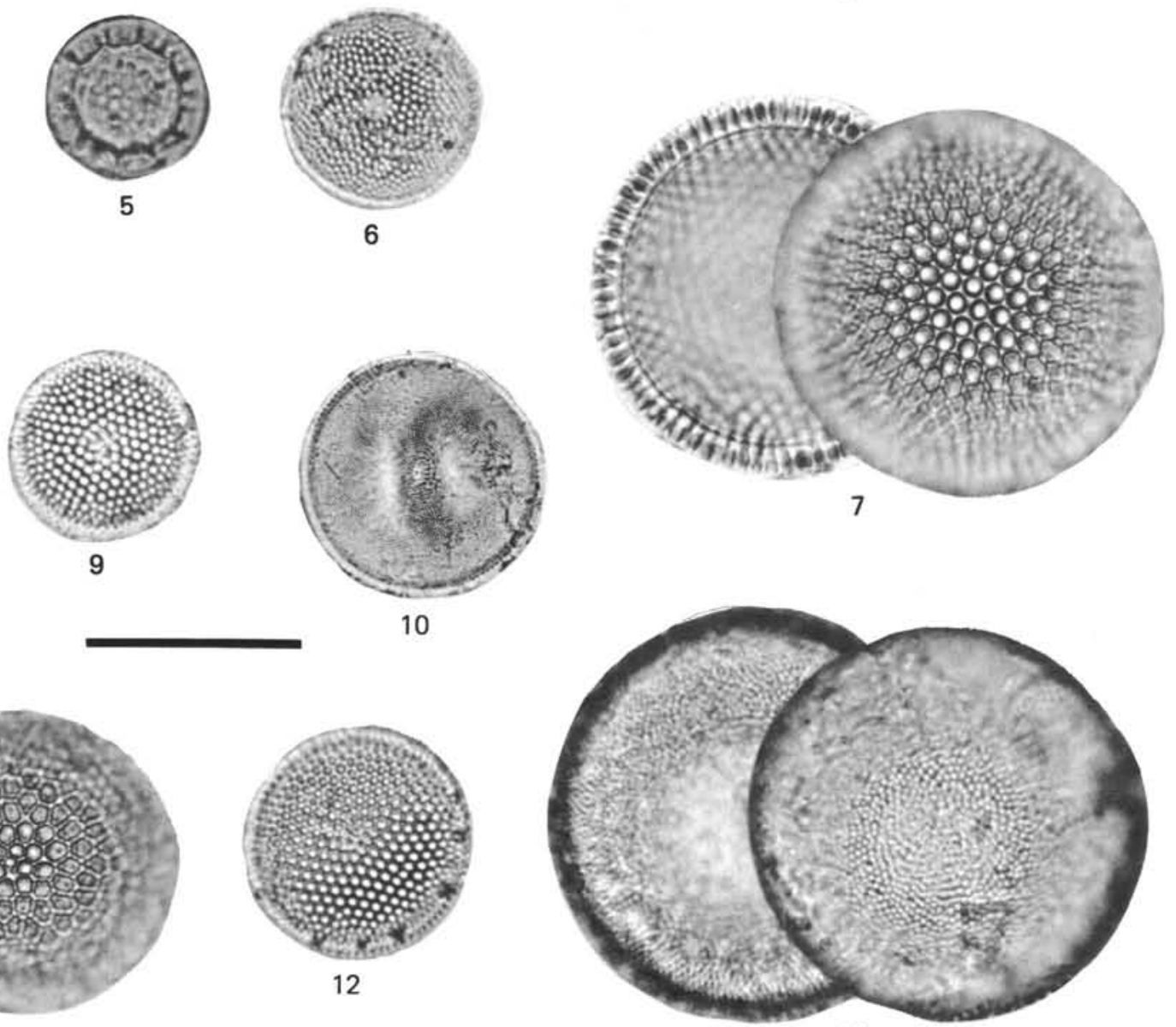

11

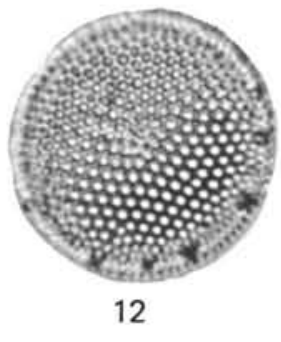

13

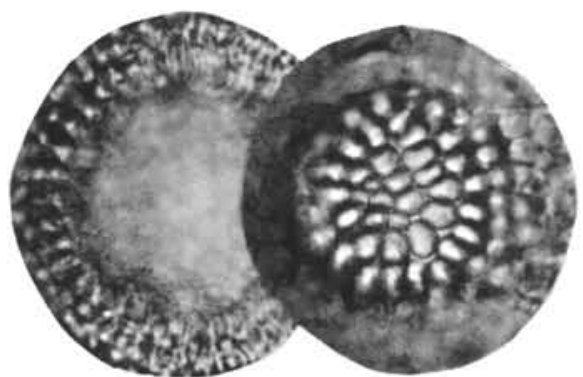

14

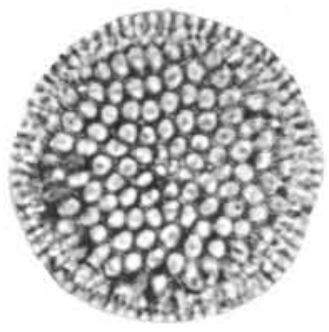

15

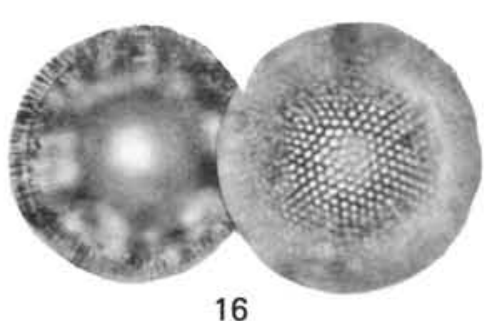

